\title{
Enhancing the Antiaromaticity of $s$-Indacene Through Naphthothiophene Fusion
}

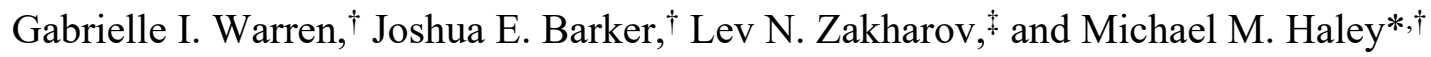 \\ †Department of Chemistry \& Biochemistry, University of Oregon, Eugene, Oregon 97403, \\ United States \\ †CAMCOR, University of Oregon, Eugene, Oregon 97403, United States
}

2. X-ray Crystallography Details

3. Computational Details

4. Copies of NMR Spectra 


\section{Experimental Details}

General. ${ }^{1} \mathrm{H},{ }^{13} \mathrm{C}$, and ${ }^{11} \mathrm{~B}$ NMR spectra were recorded in $\mathrm{CDCl}_{3}$ at room temperature using either a Bruker Avance III HD $500 \mathrm{MHz}$ equipped with a Prodigy multinuclear cryoprobe $\left({ }^{1} \mathrm{H}\right.$ : $\left.500 \mathrm{MHz},{ }^{13} \mathrm{C}: 126 \mathrm{MHz},{ }^{11} \mathrm{~B}: 160 \mathrm{MHz}\right)$ or a Bruker Avance III HD $600 \mathrm{MHz}\left({ }^{1} \mathrm{H}: 600.02 \mathrm{MHz}\right.$, $\left.{ }^{13} \mathrm{C}: 150.89 \mathrm{MHz}\right)$ NMR spectrometer with Prodigy multinuclear broadband cryoprobe. Chemical shifts $(\delta)$ are expressed in ppm relative to the residual non-deuterated solvent $\left(\mathrm{CDCl}_{3},{ }^{1} \mathrm{H}: 7.26\right.$ ppm, ${ }^{13} \mathrm{C}: 77.16 \mathrm{ppm} ; \mathrm{CD}_{2} \mathrm{Cl}_{2},{ }^{1} \mathrm{H} 5.32 \mathrm{ppm},{ }^{13} \mathrm{C}: 54.00 \mathrm{ppm}$ ). UV-vis spectra were recorded on an Agilent Technologies Care $60 \mathrm{UV}$-vis spectrometer in HPLC grade $\mathrm{CHCl}_{3}$. HRMS were recorded on a Waters XEVOG2-XS TOF mass spectrometer. Unless stated otherwise, all solvents and reagents were used as received.

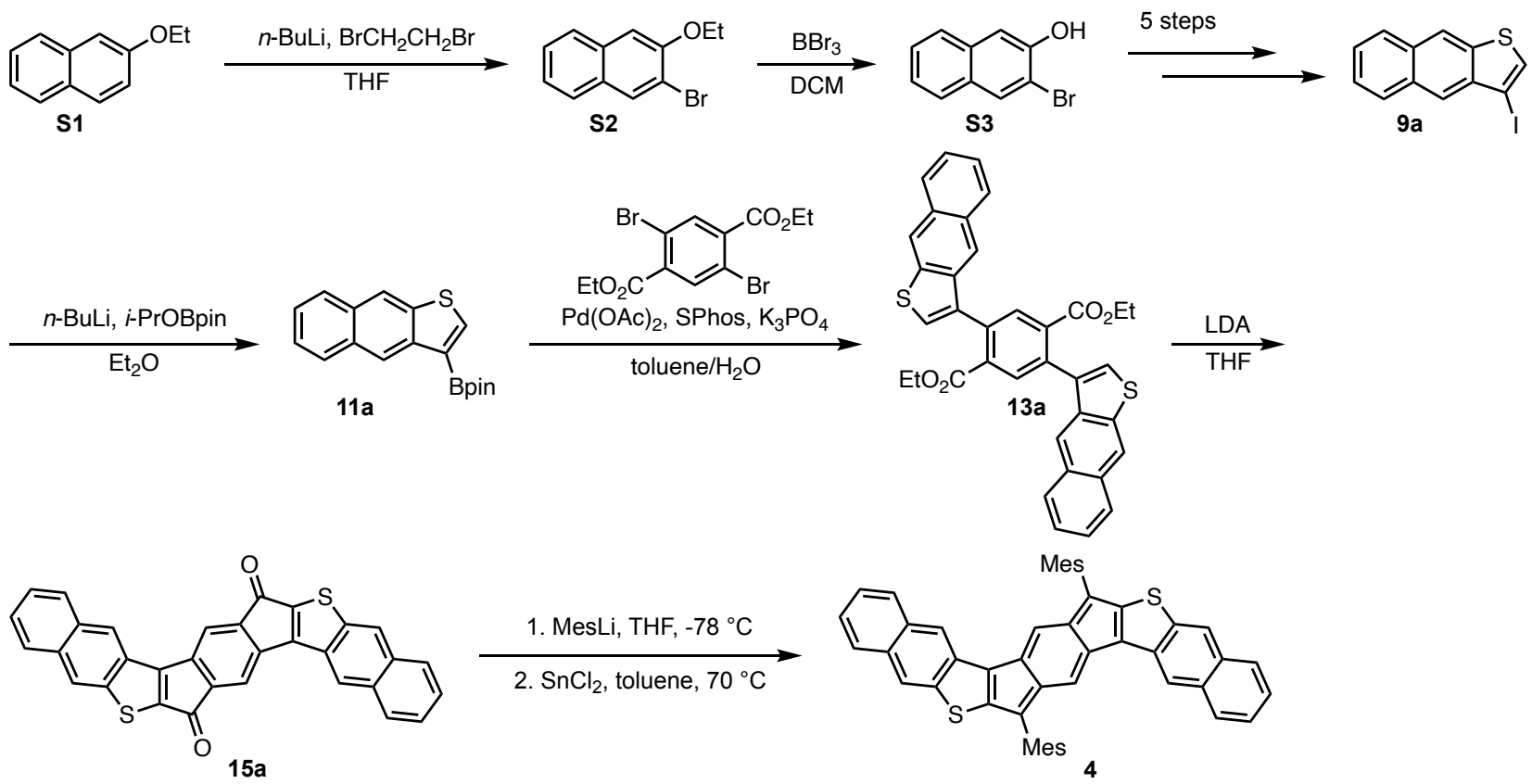

Figure S1. Synthetic route for $s y n$-IDNT 4.

2-Bromo-3-ethoxynaphthalene (S2). Adapted from a literature report, ${ }^{1}$ dry THF $(30 \mathrm{~mL})$ was added to a flame dried flask with 2-ethoxynaphthalene $(5 \mathrm{~g}, 29.03 \mathrm{mmol})$ and the mixture cooled to $-78^{\circ} \mathrm{C}$ for $10 \mathrm{~min} . n$ - $\mathrm{BuLi}(36.3 \mathrm{~mL}, 1.6 \mathrm{M}, 58.1 \mathrm{mmol})$ was added and the mixture was stirred at room temperature for $1 \mathrm{~h}$. The mixture was then cooled to $-78{ }^{\circ} \mathrm{C}$ and dry dibromoethane $(5.23 \mathrm{~mL}, 60.1 \mathrm{mmol})$ was added. The reaction was quenched with a $5 \% \mathrm{NH}_{4} \mathrm{Cl}$ aq. soln, extracted $3 \mathrm{x}$ with DCM, washed once with brine, dried $\left(\mathrm{MgSO}_{4}\right)$, and concentrated. The residue was recrystallized from hexanes to give $\mathbf{S 2}(5 \mathrm{~g}, 69 \%)$ as a white solid. ${ }^{2,3}{ }^{1} \mathrm{H} \mathrm{NMR}\left(600 \mathrm{MHz}, \mathrm{CDCl}_{3}\right)$ $\delta 8.06(\mathrm{~s}, 1 \mathrm{H}), 7.69(\mathrm{t}, J=9.0 \mathrm{~Hz}, 2 \mathrm{H}), 7.45(\mathrm{ddd}, J=8.2,6.8,1.3 \mathrm{~Hz}, 1 \mathrm{H}), 7.36$ (ddd, $J=8.1,6.9$, 
$1.2 \mathrm{~Hz}, 1 \mathrm{H}), 7.14(\mathrm{~s}, 1 \mathrm{H}), 4.20(\mathrm{q}, J=7.0 \mathrm{~Hz}, 2 \mathrm{H}), 1.55(\mathrm{t}, J=7.0 \mathrm{~Hz}, 3 \mathrm{H}) .{ }^{13} \mathrm{C} \mathrm{NMR}(151 \mathrm{MHz}$, $\left.\mathrm{CDCl}_{3}\right) \delta 153.1,133.7,132.3,129.4,126.8,126.7,126.7,124.5,113.9,107.7,64.8,14.7$.

3-Bromo-2-naphthol (S3). Adapted from literature report, ${ }^{1}$ dry DCM (40 mL) was added to a flame dried flask with $\mathbf{S 2}(5 \mathrm{~g}, 19.9 \mathrm{mmol})$ and then cooled to $-78{ }^{\circ} \mathrm{C}$ for $10 \mathrm{~min} . \mathrm{BBr}_{3}(31.8$ $\mathrm{mL}, 1.0 \mathrm{M}, 31.8 \mathrm{mmol}$ ) was added dropwise, and the mixture was warmed to room temperature overnight. The reaction was quenched with ice-cold water, extracted with DCM (3x), washed once with brine, dried $\left(\mathrm{MgSO}_{4}\right)$, and concentrated. The crude off-white solid (4.372 g, 98\%) was used without further purification. Characterization matched literature values. ${ }^{1}$

Compound 9a. This molecule was prepared from S3 following the published procedures of Tovar et al. ${ }^{4}$

Compound 11a. Dry $\mathrm{Et}_{2} \mathrm{O}(20 \mathrm{~mL})$ was added to an oven-dried flask containing 3iodonaphthothiophene $(0.3067 \mathrm{~g}, 0.99 \mathrm{mmol})$ and the mixture was cooled to $-78{ }^{\circ} \mathrm{C} . n-\mathrm{BuLi}(0.68$ $\mathrm{mL}, 1.6 \mathrm{M}, 1.09 \mathrm{mmol})$ was added dropwise and stirred for $30 \mathrm{~min}$, then $i$-PrOBpin $(0.30 \mathrm{~mL}, 1.48$ mmol) was added dropwise and the reaction warmed to room temperature overnight. The mixture was quenched with water, extracted with hexanes, and the organic layers were washed with brine, dried $\left(\mathrm{MgSO}_{4}\right)$, and concentrated. The crude yellow-orange solid was used without further purification (0.296 g, 96\%). ${ }^{1} \mathrm{H}$ NMR $\left(500 \mathrm{MHz}, \mathrm{CDCl}_{3}\right) \delta 8.86(\mathrm{~s}, 1 \mathrm{H}), 8.38(\mathrm{~s}, 1 \mathrm{H}), 8.18(\mathrm{~s}, 1 \mathrm{H})$, 8.10-8.05 (m, 1H), 7.93-7.88 (m, 1H), 7.50-7.45 (m, 2H), 1.44 (s, 12H). ${ }^{13} \mathrm{C}$ NMR (126 MHz, $\left.\mathrm{CDCl}_{3}\right) \delta 141.7,141.5,139.6,131.2,130.9,128.9,127.3,125.3,124.8,123.9,120.4,83.9,25.1$. ${ }^{11} \mathrm{~B}$ NMR $\left(160 \mathrm{MHz}, \mathrm{CDCl}_{3}\right) \delta$ 29.06. HRMS (ASAP) $\mathrm{m} / z$ : $[\mathrm{M}+\mathrm{H}]^{+}$Calcd for $\mathrm{C}_{18} \mathrm{H}_{20}{ }^{10} \mathrm{BO}_{2} \mathrm{~S}$ 310.1313; Found 310.1314.

Diester 13a. Toluene $(25 \mathrm{~mL})$ and water $(0.5 \mathrm{~mL})$ were sparged with $\mathrm{N}_{2}$ for $30 \mathrm{~min}$. In a separate flask, naphthothiophene boronic ester 11a (0.72 g, $2.32 \mathrm{mmol})$, diethyl 2,5dibromoterephthalate $(0.399 \mathrm{~g}, 1.055 \mathrm{mmol}), \mathrm{Pd}(\mathrm{OAc})_{2}(0.0095 \mathrm{~g}, 0.042 \mathrm{mmol})$, SPhos $(0.034 \mathrm{~g}$, $0.084 \mathrm{mmol})$, and $\mathrm{K}_{3} \mathrm{PO}_{4}(0.672 \mathrm{~g}, 3.16 \mathrm{mmol})$ were put under $\mathrm{N}_{2}$ atmosphere, and the sparged mixture of toluene/water was added. The reaction mixture was heated (sand bath) at reflux overnight. After cooling, the reaction was quenched with water and any solids were filtered. The remaining filtrate was extracted with DCM and the combined organic layers were dried $\left(\mathrm{MgSO}_{4}\right)$, concentrated, and triturated with toluene to afford $13 \mathrm{a}(0.49 \mathrm{~g}, 79 \%)$ as a yellow solid. ${ }^{1} \mathrm{H}$ NMR $\left(600 \mathrm{MHz} \mathrm{CDCl}_{3}\right) \delta 8.43(\mathrm{~s}, 1 \mathrm{H}), 8.17(\mathrm{~s}, 1 \mathrm{H}), 8.06(\mathrm{~s}, 1 \mathrm{H}), 7.95(\mathrm{t}, J=9.0 \mathrm{~Hz}, 2 \mathrm{H}), 7.54(\mathrm{~s}, 1 \mathrm{H})$, $7.51(\mathrm{t}, J=7.2 \mathrm{~Hz}, 1 \mathrm{H}), 7.47(\mathrm{t}, J=7.5 \mathrm{~Hz}, 1 \mathrm{H}), 3.88(\mathrm{q}, J=7.1 \mathrm{~Hz}, 2 \mathrm{H}), 0.68(\mathrm{t}, J=7.1 \mathrm{~Hz}, 3 \mathrm{H})$. 
${ }^{13} \mathrm{C}$ NMR $\left(126 \mathrm{MHz}, \mathrm{CDCl}_{3}\right) \delta 167.2,138.5,138.2,135.8,135.7,135.2,133.5,131.2,131.1$, 128.6, 127.4, 126.0, 125.7, 125.3, 121.2, 120.9, 61.6, 13.5. HRMS (ASAP) $m / z:[\mathrm{M}+\mathrm{H}]^{+} \mathrm{Calcd}$ for $\mathrm{C}_{36} \mathrm{H}_{27} \mathrm{O}_{4} \mathrm{~S}_{2}$ 587.1351; Found 587.1353.

Dione 15a. LDA was prepared by cooling dry DIPA $(0.275 \mathrm{~g}, 0.38 \mathrm{~mL}, 2.72 \mathrm{mmol})$ in THF $(15 \mathrm{~mL})$ to $-78{ }^{\circ} \mathrm{C}$, then $n$-BuLi $(1.61 \mathrm{~mL}, 1.6 \mathrm{M}, 2.583 \mathrm{mmol})$ was added dropwise and the reaction stirred at $-78{ }^{\circ} \mathrm{C}$ for $30 \mathrm{~min}$. The LDA mixture was warmed to $0{ }^{\circ} \mathrm{C}$ and added to a sonicated solution of diester 13a $(0.160 \mathrm{~g}, 0.272 \mathrm{mmol})$ and THF $(15 \mathrm{~mL})$ also at $0{ }^{\circ} \mathrm{C}$. Upon addition of LDA, the green reaction mixture was warmed to room temperature over $5 \mathrm{~h}$. The reaction was quenched with $5 \% \mathrm{NH}_{4} \mathrm{Cl}$ aq. soln, filtered, and the solids washed with DCM and acetone to afford a green solid $(0.0917 \mathrm{~g}, 68 \%)$. As is characteristic with these diones, very poor solubility precluded the acquisition of NMR data for 15a. HRMS (ASAP) $m / z$ : $[\mathrm{M}+\mathrm{H}]^{+} \mathrm{Calcd}$ for $\mathrm{C}_{32} \mathrm{H}_{15} \mathrm{O}_{2} \mathrm{~S}_{2}$ 495.0513; Found 495.0516.

IDNT 4. A flame dried flask containing dry THF $(15 \mathrm{~mL})$ and bromomesitylene $(0.363 \mathrm{~mL}$, $2.37 \mathrm{mmol})$ was cooled to $-78^{\circ} \mathrm{C}$ for about $10 \mathrm{~min}$, then $n$-BuLi $(1.41 \mathrm{~mL}, 1.6 \mathrm{M}, 2.25 \mathrm{mmol})$ was added dropwise. The reaction was stirred for $30 \mathrm{~min}$ and added to a dry THF $(5 \mathrm{~mL})$ solution of 15a $(0.117 \mathrm{~g}, 0.237 \mathrm{mmol})$ at $-78^{\circ} \mathrm{C}$. After warming the solution to room temperature overnight, the reaction was quenched with $5 \% \mathrm{NH}_{4} \mathrm{Cl}$ soln and extracted with DCM. The organic phase was washed with brine, dried $\left(\mathrm{MgSO}_{4}\right)$, and concentrated under reduced pressure to give the crude diol as a yellow solid.

Under $\mathrm{N}_{2}$ the crude diol $(0.046 \mathrm{~g}, 0.062 \mathrm{mmol})$ and $\mathrm{SnCl}_{2}(0.047 \mathrm{~g}, 0.249 \mathrm{mmol})$ were dissolved in dry toluene $(10 \mathrm{~mL})$ and heated (sand bath) to $70{ }^{\circ} \mathrm{C}$. The solution became a dark green color and upon completion (ca. $4 \mathrm{~h}$ ). The cooled mixture was filtered through celite eluting with DCM, the filtrate was concentrated, and triturated with $\mathrm{MeCN}$ to yield 4 (14.4 $\mathrm{mg}, 33 \%)$ as a dark blue solid. ${ }^{1} \mathrm{H}$ NMR $\left(600 \mathrm{MHz}, \mathrm{CDCl}_{3}\right) \delta 7.89(\mathrm{~s}, 1 \mathrm{H}), 7.79-7.74(\mathrm{~m}, 2 \mathrm{H}), 7.68-7.63(\mathrm{~m}$, 1H), 7.35-7.31 (m, 2H), 7.02 (s, 2H), 5.99 (s, 1H), 2.50 (s, 6H), 2.40 (s, 3H). ${ }^{13} \mathrm{C}$ NMR (151 MHz, $\left.\mathrm{CDCl}_{3}\right) \delta 149.4,148.4,144.8,141.6,139.1,138.3,136.8,135.7,132.1,132.0,131.5,129.4,128.7$, 128.39, 127.4, 125.8, 125.6, 125.3, 122.3, 120.1, 21.4, 21.0. HRMS (ASAP) $m / z:[\mathrm{M}+\mathrm{H}]^{+} \mathrm{Calcd}$ for $\mathrm{C}_{50} \mathrm{H}_{37} \mathrm{~S}_{2}$ 701.2337; Found 701.2337. UV-vis $\left(\mathrm{CH}_{2} \mathrm{Cl}_{2}\right) \lambda_{\max }(\varepsilon) 278(26,100), 340(21,600)$, $697(10,500) \mathrm{nm}$. 


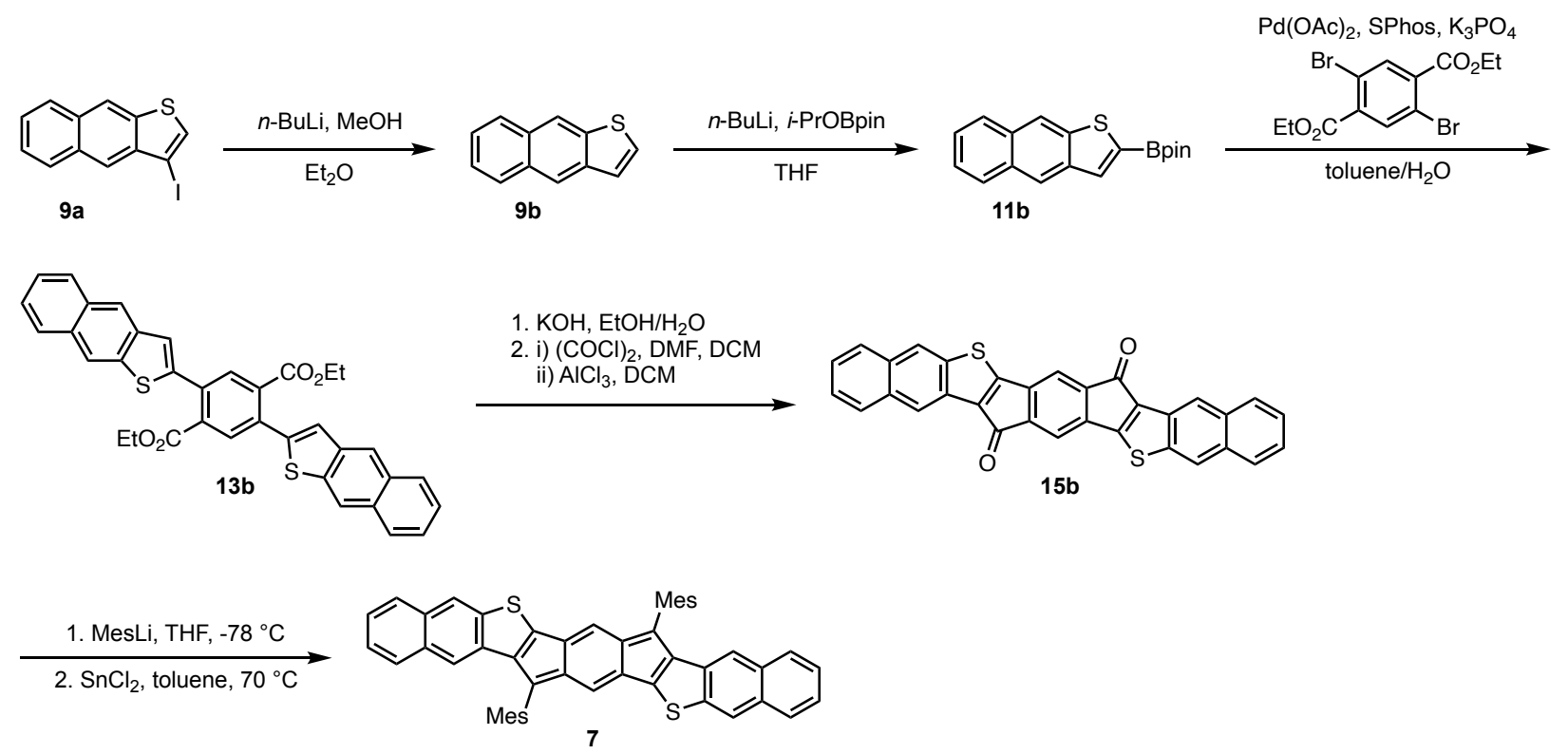

Figure S2. Synthetic route for anti-IDNT 7.

Naphtho[2,3-b]thiophene (9b). An oven dried flask containing 9a (2.0 g, $6.45 \mathrm{mmol})$ and dry $\mathrm{Et}_{2} \mathrm{O}(60 \mathrm{~mL})$ was cooled to $-78{ }^{\circ} \mathrm{C} . n-\mathrm{BuLi}(4.03 \mathrm{~mL}, 1.6 \mathrm{M}, 6.45 \mathrm{mmol})$ was added dropwise and stirred for $30 \mathrm{~min}$. $\mathrm{MeOH}(3.13 \mathrm{~mL}, 77.4 \mathrm{mmol})$ was then added dropwise and the reaction was warmed to room temperature overnight. The mixture was quenched with water, extracted $3 \mathrm{x}$ with $\mathrm{DCM}$, once with brine, dried $\left(\mathrm{MgSO}_{4}\right)$, and concentrated. A short chromatographic plug $\left(\mathrm{SiO}_{2}, 7: 3\right.$ hexanes:DCM) afforded an off-white product $(1.14 \mathrm{~g}, 96 \%)$ that matched previous characterization. $^{5}$

Compound 11b. An oven-dried flask containing $9 \mathrm{~b}(1.14 \mathrm{~g}, 6.16 \mathrm{mmol})$ and THF $(60 \mathrm{~mL})$ was cooled to $-78{ }^{\circ} \mathrm{C}$ and then $n$ - $\mathrm{BuLi}(4.24 \mathrm{~mL}, 1.6 \mathrm{M}$ solution, $6.78 \mathrm{mmol})$ was added dropwise. After stirring for $30 \mathrm{~min}, i$-PrOBpin $(1.89 \mathrm{~mL}, 9.24 \mathrm{mmol})$ was added dropwise and the reaction mixture was warmed to room temperature overnight. The reaction was quenched with water and extracted with hexanes. The organic layers were washed with brine, dried $\left(\mathrm{MgSO}_{4}\right)$, and concentrated. The resulting orange solid $(1.091 \mathrm{~g}, 57 \%)$ was used without further purification. ${ }^{1} \mathrm{H}$ NMR (500 MHz, CDCl $)_{3} \delta 8.41(\mathrm{~s}, 1 \mathrm{H}), 8.39(\mathrm{~s}, 1 \mathrm{H}), 8.02(\mathrm{~s}, 1 \mathrm{H}), 7.99(\mathrm{~d}, J=8.0 \mathrm{~Hz}, 1 \mathrm{H}), 7.92$ $(\mathrm{d}, J=8.1 \mathrm{~Hz}, 1 \mathrm{H}), 7.52-7.44(\mathrm{~m}, 2 \mathrm{H}), 1.42(\mathrm{~s}, 12 \mathrm{H}) .{ }^{13} \mathrm{C} \mathrm{NMR}\left(126 \mathrm{MHz}, \mathrm{CDCl}_{3}\right) \delta 141.4,139.9$, $134.5,131.8,131.0,128.7,127.5,125.8,125.0,123.0,120.6,84.7,25.0 .{ }^{11} \mathrm{~B}$ NMR (160 MHz, $\left.\mathrm{CDCl}_{3}\right) \delta$ 29.51. HRMS (ASAP) $\mathrm{m} / z$ : $[\mathrm{M}+\mathrm{H}]^{+}$Calcd for $\mathrm{C}_{18} \mathrm{H}_{20}{ }^{11} \mathrm{BO}_{2} \mathrm{~S} 311.1277$; Found 311.1269.

Diester 13b. Toluene $(25 \mathrm{~mL})$ and water $(0.5 \mathrm{~mL})$ were sparged with $\mathrm{N}_{2}$ for $30 \mathrm{~min}$. In a separate flask, 11b (1.09 g, $3.51 \mathrm{mmol})$, diethyl 2,5-dibromoterephthalate $(0.603 \mathrm{~g}, 1.596 \mathrm{mmol})$, 
$\mathrm{Pd}(\mathrm{OAc})_{2}(0.0143 \mathrm{~g}, 0.064 \mathrm{mmol})$, SPhos (0.0524 g, $\left.0.128 \mathrm{mmol}\right)$, and $\mathrm{K}_{3} \mathrm{PO}_{4}(1.017 \mathrm{~g}, 4.79$ mmol) were put under $\mathrm{N}_{2}$ atmosphere, and the sparged mixture of toluene/water was added. The reaction mixture was heated (sand bath) at reflux overnight. After cooling, the reaction was quenched with water and any solids were filtered. The remaining filtrate was extracted with DCM and the combined organic layers were dried $\left(\mathrm{MgSO}_{4}\right)$, concentrated, and triturated with toluene to afford $13 b(0.49 \mathrm{~g}, 78 \%)$ as a yellow solid. ${ }^{1} \mathrm{H}$ NMR $\left(500 \mathrm{MHz}, \mathrm{CDCl}_{3}\right) \delta 8.35(\mathrm{~s}, 1 \mathrm{H}), 8.31$ (s, 1H), $8.04(\mathrm{~s}, 1 \mathrm{H}), 8.01-7.95(\mathrm{~m}, 1 \mathrm{H}), 7.96-7.90(\mathrm{~m}, 1 \mathrm{H}), 7.54-7.45(\mathrm{~m}, 2 \mathrm{H}), 7.43(\mathrm{~s}, 1 \mathrm{H}), 4.24(\mathrm{q}$, $J=7.1 \mathrm{~Hz}, 2 \mathrm{H}), 1.07(\mathrm{t}, J=7.1 \mathrm{~Hz}, 3 \mathrm{H}) .{ }^{13} \mathrm{C} \mathrm{NMR}\left(126 \mathrm{MHz}, \mathrm{CDCl}_{3}\right) \delta 167.4,142.3,142.2$, $139.4,138.9,134.5,134.5,132.4,131.4,128.4,127.5,125.7,125.3,123.4,122.3,120.4,62.1$, 13.9. HRMS (ASAP) $m / z:[\mathrm{M}+\mathrm{H}]^{+}$Calcd for $\mathrm{C}_{36} \mathrm{H}_{27} \mathrm{O}_{4} \mathrm{~S}_{2} 587.1351$; Found 587.1353.

Dione 15b. A mixture of 13b $(0.733 \mathrm{~g}, 1.25 \mathrm{mmol})$, EtOH $(80 \mathrm{~mL}), \mathrm{H}_{2} \mathrm{O}(20 \mathrm{~mL})$, and $\mathrm{KOH}$ (0.701 g, $12.5 \mathrm{mmol})$ was refluxed in a sand bath for ca. $48 \mathrm{~h}$. The reaction was concentrated to remove the $\mathrm{EtOH}$ and the resulting aqueous solution was acidified by dropwise addition of $\mathrm{HCl}$ ( 3 M). The resulting precipitate was collected, washed with $\mathrm{H}_{2} \mathrm{O}$, and dried overnight in an oven to yield a greenish-yellow solid. To a solution of the diacid $(0.508 \mathrm{~g}, 0.957 \mathrm{mmol})$ in DCM $(50 \mathrm{~mL})$, oxalyl chloride $(0.32 \mathrm{~mL}, 3.83 \mathrm{mmol})$ and DMF $(0.148 \mathrm{~mL}, 1.913 \mathrm{mmol})$ were added. The reaction mixture went from orange to dark yellow and was stirred at room temperature overnight. The DCM was removed under reduced pressure. Solid $\mathrm{AlCl}_{3}(0.638 \mathrm{~g}, 4.78 \mathrm{mmol})$ was added to the crude acid chloride and the mixture was dissolved in DCM $(50 \mathrm{~mL})$. The black reaction mixture was stirred overnight, and then the mixture was poured over $\mathrm{HCl}(3 \mathrm{M})$ at $0{ }^{\circ} \mathrm{C}$. The precipitated dione was filtered, washed with water, DCM, and acetone. The resulting green solid (0.308 g, $53 \%$ ) was too poorly soluble to obtain NMR spectra. HRMS (ASAP) $m / z$ : $[\mathrm{M}+\mathrm{H}]^{+}$Calcd for $\mathrm{C}_{32} \mathrm{H}_{15} \mathrm{O}_{2} \mathrm{~S}_{2}$ 495.0513; Found 495.0522.

IDNT 7. A flame dried flask containing dry THF $(20 \mathrm{~mL})$ and bromomesitylene $(0.31 \mathrm{~mL}$, $2.02 \mathrm{mmol})$ was cooled to $-78^{\circ} \mathrm{C}$ for about $10 \mathrm{~min}$, then $n$-BuLi $(1.2 \mathrm{~mL}, 1.6 \mathrm{M}, 1.92 \mathrm{mmol})$ was added dropwise. The reaction was stirred for $30 \mathrm{~min}$ and added to a dry THF $(5 \mathrm{~mL})$ solution of 15b $(0.1 \mathrm{~g}, 0.202 \mathrm{mmol})$ at $-78^{\circ} \mathrm{C}$. After warming the solution to room temperature overnight, the reaction was quenched with $5 \% \mathrm{NH}_{4} \mathrm{Cl}$ aq. soln and extracted with DCM. The organic phase was washed with brine, dried $\left(\mathrm{MgSO}_{4}\right)$, and concentrated to give the crude diol (0.0215 g) as a yellow solid.

Under $\mathrm{N}_{2}$ the crude diol $(0.0213 \mathrm{~g}, 0.029 \mathrm{mmol})$ and $\mathrm{SnCl}_{2}(0.022 \mathrm{~g}, 0.116 \mathrm{mmol})$ were dissolved in dry toluene $\left(10 \mathrm{~mL}\right.$ ) and heated (sand bath) to $70^{\circ} \mathrm{C}$. The solution became a dark blue color and upon completion (ca. $4 \mathrm{~h}$ ), the mixture was filtered through celite eluting with DCM, the 
filtrate was concentrated and triturated with $\mathrm{MeCN}$ to give 7 (17.6 mg, 51\%) as a deep blue solid. ${ }^{1} \mathrm{H}$ NMR (600 MHz, $\left.\mathrm{CDCl}_{3}\right) \delta 7.89(\mathrm{~s}, 1 \mathrm{H}), 7.66(\mathrm{~d}, J=8.0 \mathrm{~Hz}, 1 \mathrm{H}), 7.52(\mathrm{~d}, J=8.2 \mathrm{~Hz}, 1 \mathrm{H})$, 7.33-7.27 (m, 2H), 7.04 (s, 2H), 6.98 (s, 1H), 6.09 (s, 1H), 2.43 (s, 3H), $2.38(\mathrm{~s}, 6 \mathrm{H}) .{ }^{13} \mathrm{C} \mathrm{NMR}$ $\left(126 \mathrm{MHz} \mathrm{CDCl}_{3}\right) \delta 167.2,138.5,138.2,135.8,135.7,135.2,133.5,131.2,131.1,128.6,127.4$, 126.0, 125.7, 125.3, 121.2, 120.8, 61.6, 13.5. HRMS (ASAP) $m / z:[\mathrm{M}+\mathrm{H}]^{+}$Calcd for $\mathrm{C}_{50} \mathrm{H}_{37} \mathrm{~S}_{2}$ 701.2337; Found 701.2335. UV-vis $\left(\mathrm{CH}_{2} \mathrm{Cl}_{2}\right) \lambda_{\max }(\varepsilon) 361$ (11,600), 415 (34,900), $665(23,200)$ nm.
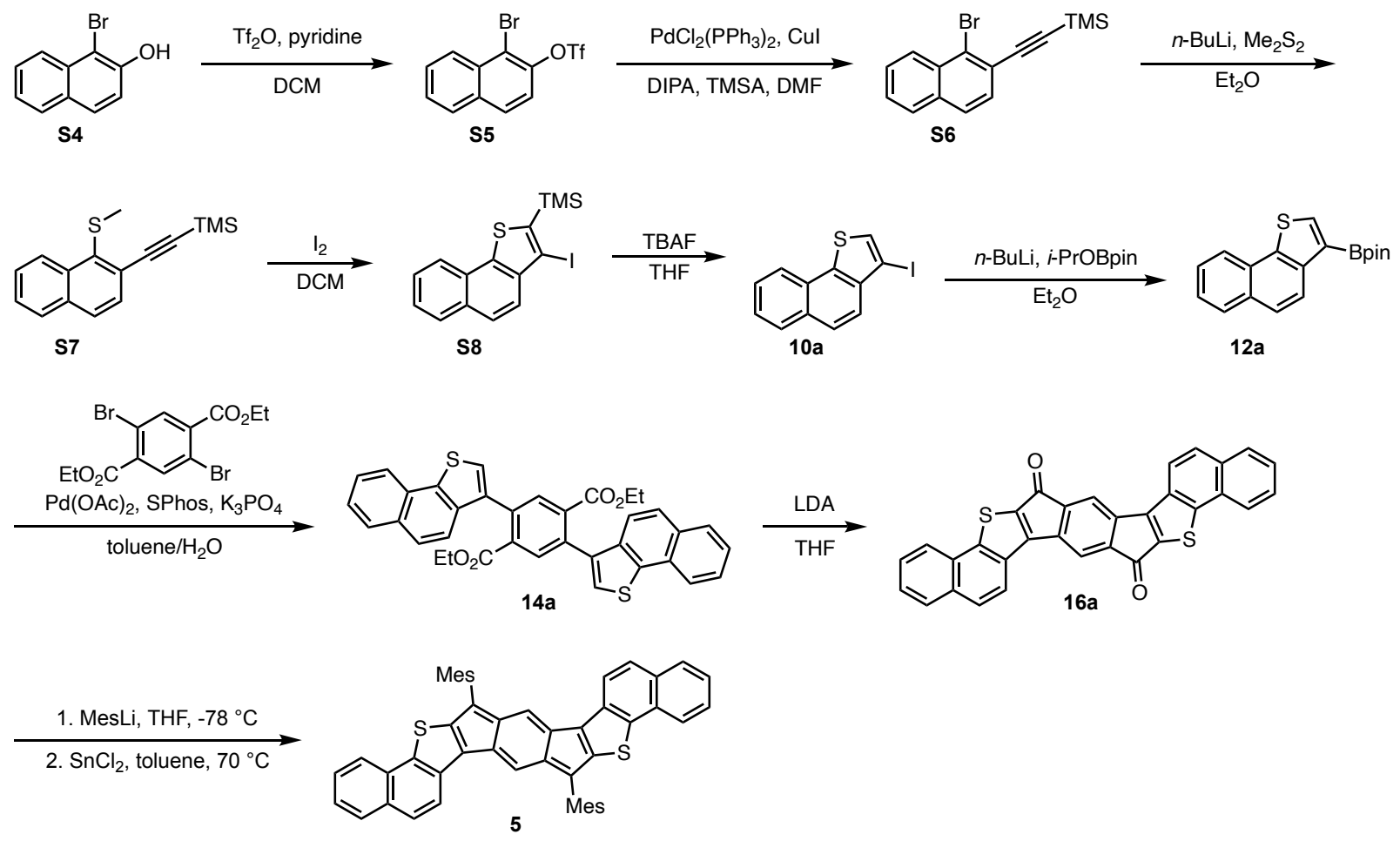

Figure S3. Synthetic route for syn-IDNT 5.

Triflate S5. This molecule was synthesized from S4 following a previously reported method. $^{4}$

1-Bromo-2-(trimethylsilyl)ethynylnaphthalene (S6). Sparged DMF (105 mL), DIPA (35 $\mathrm{mL})$ and TMSA $(7.7 \mathrm{~mL}, 78.4 \mathrm{mmol})$ were added to an oven-dried flask with $\mathrm{PdCl}_{2}\left(\mathrm{PPh}_{3}\right)_{2}(0.638$ g, $0.909 \mathrm{mmol}), \mathrm{CuI}(0.194 \mathrm{~g}, 0.056 \mathrm{mmol})$, and $\mathbf{S 5}(6.456 \mathrm{~g}, 18.18 \mathrm{mmol})$. The reaction was stirred at room temperature for $5 \mathrm{~d}$ and then quenched with $5 \% \mathrm{NH}_{4} \mathrm{Cl}$ aq. soln. The mixture was extracted 3x with hexanes and the organic layers were washed with 5\% aq. LiCl soln, dried $\left(\mathrm{MgSO}_{4}\right)$ and concentrated. A short chromatographic plug $\left(\mathrm{SiO}_{2}, \mathrm{DCM}\right)$ was run to yield an orange solid (5.3 g, 96\%) whose spectroscopic data matched previous reports. ${ }^{6}$ 
Sulfide S7. Dry Et ${ }_{2} \mathrm{O}(290 \mathrm{~mL})$ was added to an oven-dried flask containing S6 (10.11 g, $33.34 \mathrm{mmol})$ and cooled to $-78^{\circ} \mathrm{C} . n$-BuLi (31.26 mL, 1.6 M solution, $\left.50.0 \mathrm{mmol}\right)$ was added dropwise and the reaction mixture stirred for $30 \mathrm{~min}$, then $\mathrm{Me}_{2} \mathrm{~S}_{2}(5.93 \mathrm{~mL}, 6.28 \mathrm{~g}, 66.7 \mathrm{mmol})$ was added dropwise and the reaction warmed to room temperature overnight. The reaction mixture was quenched with water and extracted with hexanes. The combined organic layers were washed with brine, dried $\left(\mathrm{MgSO}_{4}\right)$, and concentrated to yield $\mathbf{S 7}(8.554 \mathrm{~g}, 95 \%)$ as a crude yellow-brown oil that was used without further purification. ${ }^{1} \mathrm{H}$ NMR $\left(500 \mathrm{MHz}, \mathrm{CDCl}_{3}\right) \delta 8.77(\mathrm{~d}, J=8.6 \mathrm{~Hz}$, $1 \mathrm{H}), 7.81(\mathrm{~d}, J=8.2 \mathrm{~Hz}, 1 \mathrm{H}), 7.74(\mathrm{~d}, J=8.4 \mathrm{~Hz}, 1 \mathrm{H}), 7.65-7.58(\mathrm{~m}, 2 \mathrm{H}), 7.53(\mathrm{t}, J=7.5 \mathrm{~Hz}, 1 \mathrm{H})$, $2.60(\mathrm{~s}, 3 \mathrm{H}), 0.41(\mathrm{~s}, 9 \mathrm{H}) .{ }^{13} \mathrm{C} \mathrm{NMR}\left(126 \mathrm{MHz}, \mathrm{CDCl}_{3}\right) \delta 137.7,134.6,133.5,129.6,128.42$, 128.40, 127.3, 126.9, 126.8, 126.6, 104.8, 100.6, 19.0, 0.1. HRMS (ASAP) $m / z:[\mathrm{M}+\mathrm{H}]^{+} \mathrm{Calcd}$ for $\mathrm{C}_{16} \mathrm{H}_{19} \mathrm{Si}^{32} \mathrm{~S} 271.0977$; Found 271.0986.

Naphthothiophene S8. Dry DCM $(50 \mathrm{~mL})$ was added to an oven-dried flask containing S7 $(8.55 \mathrm{~g}, 31.6 \mathrm{mmol})$ and the mixture placed in a water bath. A solution of $\mathrm{I}_{2}(12.84 \mathrm{~g}, 50.6 \mathrm{mmol})$ was added and stirred for $10 \mathrm{~min}$. The reaction mixture was diluted with water and extracted with DCM. The organic layers were washed with aq. $\mathrm{Na}_{2} \mathrm{~S}_{2} \mathrm{O}_{3}$ soln, dried $\left(\mathrm{MgSO}_{4}\right)$, and concentrated to yield S8 (11.05 g, 91\%) as a crude brown solid that was used without further purification. ${ }^{1} \mathrm{H}$ NMR $\left(500 \mathrm{MHz}, \mathrm{CDCl}_{3}\right) \delta 8.17(\mathrm{~d}, J=8.1 \mathrm{~Hz}, 1 \mathrm{H}), 7.95(\mathrm{~d}, J=8.0 \mathrm{~Hz}, 1 \mathrm{H}), 7.83-7.77(\mathrm{~m}, 2 \mathrm{H})$, $7.59(\mathrm{t}, J=7.5 \mathrm{~Hz}, 1 \mathrm{H}), 7.54(\mathrm{t}, J=8.1 \mathrm{~Hz}, 1 \mathrm{H}), 0.56(\mathrm{~s}, 9 \mathrm{H}) .{ }^{13} \mathrm{C} \mathrm{NMR}\left(126 \mathrm{MHz}, \mathrm{CDCl}_{3}\right) \delta$ $140.9,139.9,139.0,131.1,129.0,128.4,127.1,126.4,123.7,123.5,88.2,-0.4$. HRMS (ASAP) $m / z:[\mathrm{M}+\mathrm{H}]^{+}$Calcd for $\mathrm{C}_{15} \mathrm{H}_{15} \operatorname{SiSI} 381.9708$; Found 381.9700 .

Naphthothiophene 10a. To a solution of S8 (11.05 g, $28.89 \mathrm{mmol})$ in THF (300 mL), TBAF (40.45 mL, 1M solution, $40.45 \mathrm{mmol}$ ) was added and stirred under atmosphere for $20 \mathrm{~min}$. The reaction mixture was quenched with aq. saturated $\mathrm{NaHCO}_{3}$ soln, extracted $3 \mathrm{x}$ with hexanes, dried $\left(\mathrm{MgSO}_{4}\right)$, and concentrated. The crude solids were sonicated with $\mathrm{MeOH}$, cooled, filtered, and washed with cold $\mathrm{MeOH}$ to yield $\mathbf{1 0 a}(7.52 \mathrm{~g}, 84 \%)$ as a light brown solid. ${ }^{1} \mathrm{H}$ NMR (500 MHz, $\left.\mathrm{CDCl}_{3}\right) \delta 8.13(\mathrm{~d}, J=8.1 \mathrm{~Hz}, 1 \mathrm{H}), 7.97(\mathrm{~d}, J=7.5 \mathrm{~Hz}, 1 \mathrm{H}), 7.83(\mathrm{~d}, J=8.7 \mathrm{~Hz}, 1 \mathrm{H}), 7.77(\mathrm{~d}, J=$ $8.8 \mathrm{~Hz}, 1 \mathrm{H}), 7.68(\mathrm{~s}, 1 \mathrm{H}), 7.61(\mathrm{t}, J=7.4 \mathrm{~Hz}, 2 \mathrm{H}), 7.55(\mathrm{t}, J=7.5 \mathrm{~Hz}, 1 \mathrm{H}) .{ }^{13} \mathrm{C} \mathrm{NMR}(126 \mathrm{MHz}$, $\left.\mathrm{CDCl}_{3}\right) \delta 138.2,136.7,131.1,129.1,128.6,127.8,127.2,126.5,126.4,123.4,123.3,79.4$. HRMS (ASAP) $m / z:[\mathrm{M}+\mathrm{H}]^{+}$Calcd for $\mathrm{C}_{12} \mathrm{H}_{8} \mathrm{SI} 310.9391$; Found 310.9392.

Bpin-naphthothiophene 12a. Dry $\mathrm{Et}_{2} \mathrm{O}(35 \mathrm{~mL})$ was added to an oven-dried flask charged with 10a $(1.0 \mathrm{~g}, 3.22 \mathrm{mmol})$ and cooled to $-78^{\circ} \mathrm{C} . n$-BuLi $(2.22 \mathrm{~mL}, 1.6 \mathrm{M}, 3.55 \mathrm{mmol})$ was added 
dropwise, the reaction was stirred for $30 \mathrm{~min}$, then $i$-PrOBpin $(0.99 \mathrm{~mL}, 4.84 \mathrm{mmol})$ was added dropwise and the reaction was warmed to room temperature overnight. The reaction was quenched with water, extracted with $\mathrm{DCM}$, dried $\left(\mathrm{MgSO}_{4}\right)$, and concentrated. The crude product was purified by silica gel plug eluting with hexanes, then DCM to collect the product $\mathbf{1 2 a}(0.739 \mathrm{~g}, 74 \%)$ as a brown solid. ${ }^{1} \mathrm{H}$ NMR $\left(500 \mathrm{MHz}, \mathrm{CDCl}_{3}\right) \delta 8.39(\mathrm{~d}, J=8.7 \mathrm{~Hz}, 1 \mathrm{H}), 8.16-8.12(\mathrm{~m}, 2 \mathrm{H}), 7.94(\mathrm{~d}$, $J=8.1 \mathrm{~Hz}, 1 \mathrm{H}), 7.76(\mathrm{~d}, J=8.7 \mathrm{~Hz}, 1 \mathrm{H}), 7.56$ (t, $J=7.5 \mathrm{~Hz}, 2 \mathrm{H}), 7.51$ (t, $J=7.5 \mathrm{~Hz}, 1 \mathrm{H}), 1.41$ (s, 12H). ${ }^{13} \mathrm{C}$ NMR $\left(126 \mathrm{MHz}, \mathrm{CDCl}_{3}\right) \delta 141.1,137.6,131.0,129.1,128.9,126.5,125.6,125.4$, 124.2, 123.9, 83.8, 83.0, 25.1, 25.0. ${ }^{11} \mathrm{~B}$ NMR $\left(160 \mathrm{MHz}, \mathrm{CDCl}_{3}\right) \delta 29.30$. HRMS (ASAP) $\mathrm{m} / z$ : $[\mathrm{M}+\mathrm{H}]^{+}$Calcd for $\mathrm{C}_{18} \mathrm{H}_{20}{ }^{11} \mathrm{BO}_{2} \mathrm{~S}$ 311.1277; Found 311.1269.

Diester 14a. $\mathrm{N}_{2}$-sparged toluene $(20 \mathrm{~mL})$ and water $(0.2 \mathrm{~mL})$ were added to an oven-dried flask containing 12a $(0.790 \mathrm{~g}, 2.55 \mathrm{mmol})$, diethyl 2,5-dibromoterephthalate $(0.323 \mathrm{~g}, 0.85 \mathrm{mmol})$, $\mathrm{Pd}(\mathrm{OAc})_{2}(0.008 \mathrm{~g}, 0.034 \mathrm{mmol})$, Sphos (0.028 g, $\left.0.068 \mathrm{mmol}\right)$, and $\mathrm{K}_{3} \mathrm{PO}_{4}(0.541 \mathrm{~g}, 2.55 \mathrm{mmol})$ and the mixture was refluxed in a sand bath. After $24 \mathrm{~h}$, additional sparged toluene $(10 \mathrm{~mL})$, water $(0.1 \mathrm{~mL}), \mathrm{Pd}(\mathrm{OAc})_{2}(0.008 \mathrm{~g}, 0.034 \mathrm{mmol})$, Sphos (0.028 g, $\left.0.068 \mathrm{mmol}\right)$, and $\mathrm{K}_{3} \mathrm{PO}_{4}(0.541 \mathrm{~g}$, $2.55 \mathrm{mmol}$ ) were added and refilux was continued overnight. After $48 \mathrm{~h}$, the reaction was cooled then filtered and the solid washed with DCM then water. The isolated material was dried in the oven to give 14a $(0.272 \mathrm{~g}, 55 \%)$ as a gray solid. ${ }^{1} \mathrm{H}$ NMR $\left(500 \mathrm{MHz}, \mathrm{CDCl}_{3}\right) \delta 8.21(\mathrm{~d}, J=8.2$ $\mathrm{Hz}, 1 \mathrm{H}), 8.13(\mathrm{~s}, 1 \mathrm{H}), 7.95(\mathrm{~d}, J=8.1 \mathrm{~Hz}, 1 \mathrm{H}), 7.74(\mathrm{~d}, J=8.7 \mathrm{~Hz}, 1 \mathrm{H}), 7.62(\mathrm{t}, J=7.6 \mathrm{~Hz}, 1 \mathrm{H})$, 7.59-7.51 (m, 3H), 3.92 (q, $J=7.1 \mathrm{~Hz}, 2 \mathrm{H}), 0.72(\mathrm{t}, J=7.1 \mathrm{~Hz}, 3 \mathrm{H}) .{ }^{13} \mathrm{C} \mathrm{NMR}\left(126 \mathrm{MHz}, \mathrm{CDCl}_{3}\right)$ $\delta$ 167.2, 137.6, 137.5, 136.7, 135.8, 134.9, 133.5, 131.1, 129.2, 129.0, 126.9, 126.1, 125.8, 123.8, 122.8, 120.8, 61.6, 13.5. HRMS (ASAP) $m / z:[\mathrm{M}+\mathrm{H}]^{+}$Calcd for $\mathrm{C}_{36} \mathrm{H}_{27} \mathrm{O}_{4} \mathrm{~S}_{2}$ 587.1351; Found 587.1353 .

Dione 16a. LDA was prepared by cooling dry DIPA $(0.661 \mathrm{~g}, 0.92 \mathrm{~mL}, 6.54 \mathrm{mmol})$ and THF $(40 \mathrm{~mL})$ to $-78{ }^{\circ} \mathrm{C}$, and then $n$-BuLi $(3.88 \mathrm{~mL}, 1.6 \mathrm{M}, 6.21 \mathrm{mmol})$ was added dropwise and the reaction stirred at $-78{ }^{\circ} \mathrm{C}$ for $10 \mathrm{~min}$. The LDA mixture was warmed to $0{ }^{\circ} \mathrm{C}$, stirred for 20 min, and added to a sonicated solution of $14 \mathbf{a}(0.384 \mathrm{~g}, 0.654 \mathrm{mmol})$ and THF $(10 \mathrm{~mL})$ also at 0 ${ }^{\circ} \mathrm{C}$. Upon addition of LDA, the reaction mixture turned teal and was stirred for $1 \mathrm{~h}$ at $0{ }^{\circ} \mathrm{C}$, and then $2 \mathrm{~h}$ at room temperature. The reaction was quenched with $5 \%$ aq. $\mathrm{NH}_{4} \mathrm{Cl}$ soln, filtered, and the solids washed with water, DCM, and acetone to afford dione $16 \mathbf{a}(0.262 \mathrm{~g}, 81 \%)$ as a brown solid. Because of very poor solubility, NMR data for 16a could not be obtained. HRMS (ASAP) $m / z:[\mathrm{M}+\mathrm{H}]^{+}$Calcd for $\mathrm{C}_{32} \mathrm{H}_{15} \mathrm{O}_{2} \mathrm{~S}_{2}$ 495.0515; Found 495.0513. 
IDNT 5. A flame-dried flask containing dry THF $(5 \mathrm{~mL})$ and bromomesitylene $(0.24 \mathrm{~mL}$, $1.58 \mathrm{mmol})$ was cooled to $-78^{\circ} \mathrm{C}$ for about $10 \mathrm{~min}$, then $n-\mathrm{BuLi}(0.94 \mathrm{~mL}, 1.6 \mathrm{M}, 1.50 \mathrm{mmol})$ was added dropwise. The reaction was stirred for $30 \mathrm{~min}$ and then added to a dry THF $(8 \mathrm{~mL})$ solution of $16 \mathbf{a}(0.078 \mathrm{~g}, 0.158 \mathrm{mmol})$ at $-78^{\circ} \mathrm{C}$. After warming the solution to room temperature overnight, the reaction was quenched with aq. $5 \% \mathrm{NH}_{4} \mathrm{Cl}$ soln and extracted with DCM. The organic phase was washed with brine, dried $\left(\mathrm{MgSO}_{4}\right)$, and concentrated under reduced pressure to give the crude diol as a yellow solid.

Under $\mathrm{N}_{2}$ the crude diol $(0.0825 \mathrm{~g}, 0.112 \mathrm{mmol})$ and $\mathrm{SnCl}_{2}(0.085 \mathrm{~g}, 0.45 \mathrm{mmol})$ were dissolved in dry toluene $(15 \mathrm{~mL})$ and heated to $70^{\circ} \mathrm{C}$. The solution became a teal green color and upon completion (ca. $4 \mathrm{~h}$ ), the mixture was filtered through celite eluting with DCM, and the filtrate was concentrated. The reaction mixture was purified via column chromatography on $\mathrm{SiO}_{2}$ (4:1 hexanes:DCM) to yield 5 (20 mg, 25\%) as a blue solid. ${ }^{1} \mathrm{H}$ NMR $\left(600 \mathrm{MHz}, \mathrm{CD}_{2} \mathrm{Cl}_{2}\right) \delta 7.80-$ $7.74(\mathrm{~m}, 2 \mathrm{H}), 7.52(\mathrm{~d}, J=8.7 \mathrm{~Hz}, 1 \mathrm{H}), 7.47-7.40(\mathrm{~m}, 3 \mathrm{H}), 7.03(\mathrm{~s}, 2 \mathrm{H}), 6.24(\mathrm{~s}, 1 \mathrm{H}), 2.44(\mathrm{~s}, 6 \mathrm{H})$, $2.38(\mathrm{~s}, 3 \mathrm{H}) .{ }^{13} \mathrm{C} \mathrm{NMR}\left(151 \mathrm{MHz}, \mathrm{CD}_{2} \mathrm{Cl}_{2}\right) \delta 148.3,145.9,144.6,143.1,138.8,137.6,137.0$, $134.7,131.7,131.5,130.3,129.8,129.5,129.0,127.6,126.9,126.5,125.0,123.5,120.7,21.5$, 20.9. HRMS (ASAP) $\mathrm{m} / z$ : $[\mathrm{M}+\mathrm{H}]^{+}$Calcd for $\mathrm{C}_{50} \mathrm{H}_{37} \mathrm{~S}_{2}$ 701.2337; Found 701.2336. UV-vis $\left(\mathrm{CH}_{2} \mathrm{Cl}_{2}\right) \lambda_{\max }(\varepsilon) 278(61,000), 326(49,900), 366(27,500), 661(42,400) \mathrm{nm}$.
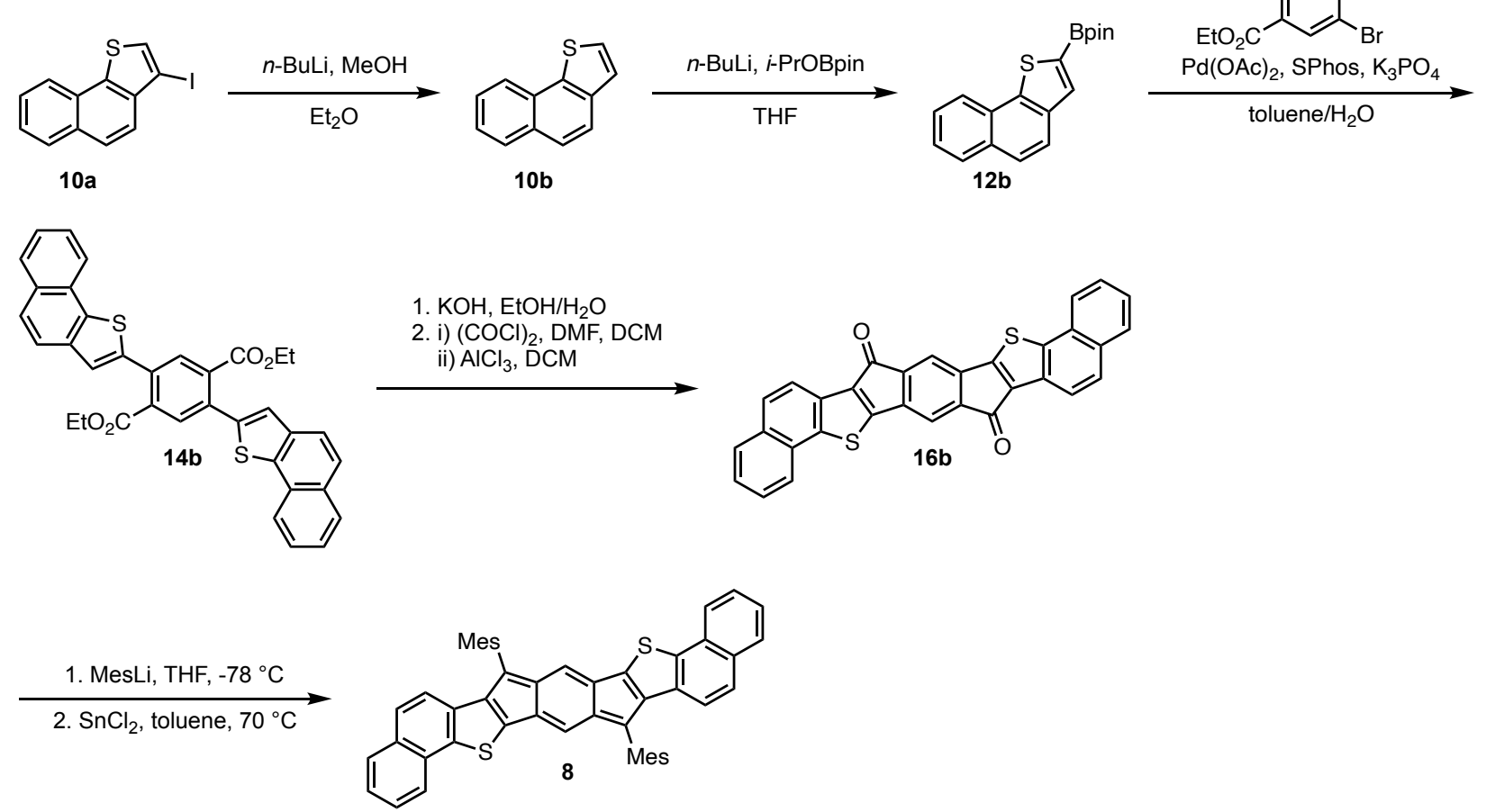

Figure S4. Synthetic route for anti-IDNT 8. 
Naphthothiophene 10b. An oven dried flask containing 10a $(2.0 \mathrm{~g}, 6.45 \mathrm{mmol})$ and dry $\mathrm{Et}_{2} \mathrm{O}(70 \mathrm{~mL})$ was cooled to $-78^{\circ} \mathrm{C} . n$ - $\mathrm{BuLi}(4.0 \mathrm{~mL}, 1.6 \mathrm{M}, 6.45 \mathrm{mmol})$ was added dropwise and stirred for $30 \mathrm{~min}$. $\mathrm{MeOH}(3.13 \mathrm{~mL}, 77.4 \mathrm{mmol})$ was then added dropwise and the reaction was warmed to room temperature overnight. The reaction was quenched with water, extracted $3 x$ with DCM, $1 \mathrm{x}$ with brine, dried $\left(\mathrm{MgSO}_{4}\right)$ and concentrated. Chromatography on a short $\mathrm{SiO}_{2}$ plug (eluted with hexanes, flushed with DCM) and concentration of the solution afforded a yellow oil $(0.91 \mathrm{~g}, 77 \%)$ that matched previous characterization. ${ }^{7}$

Bpin-naphthothiophene 12b. Dry THF $(50 \mathrm{~mL})$ was added to an oven-dried flask containing 10b $(0.91 \mathrm{~g}, 4.94 \mathrm{mmol})$ and then cooled to $-78^{\circ} \mathrm{C} . n$-BuLi $(3.4 \mathrm{~mL}, 1.6 \mathrm{M}, 5.44 \mathrm{mmol})$ was added dropwise and the green solution was stirred for $30 \mathrm{~min}$, then $i$-PrOBpin (1.38 g, 7.41 mmol) was added dropwise and the reaction was warmed to room temperature overnight. The reaction was quenched with water, extracted with hexanes, and the organic layers were washed with brine, dried $\left(\mathrm{MgSO}_{4}\right)$, and concentrated. The yellow oily solid $(0.831 \mathrm{~g}, 54 \%)$ was used without further purification. ${ }^{1} \mathrm{H}$ NMR $\left(500 \mathrm{MHz}, \mathrm{CDCl}_{3}\right) \delta 8.22(\mathrm{~d}, J=8.1 \mathrm{~Hz}, 1 \mathrm{H}), 8.03(\mathrm{~s}, 1 \mathrm{H})$, $7.93(\mathrm{~d}, J=8.0 \mathrm{~Hz}, 1 \mathrm{H}), 7.84(\mathrm{~d}, J=8.7 \mathrm{~Hz}, 1 \mathrm{H}), 7.72$ (d, $J=8.7 \mathrm{~Hz}, 1 \mathrm{H}), 7.60$ (ddd, $J=8.2,6.9$, $1.4 \mathrm{~Hz}, 1 \mathrm{H}), 7.55$ (ddd, $J=8.2,6.9,1.4 \mathrm{~Hz}, 1 \mathrm{H}), 1.42(\mathrm{~s}, 12 \mathrm{H}) .{ }^{13} \mathrm{C} \mathrm{NMR}\left(126 \mathrm{MHz}, \mathrm{CDCl}_{3}\right) \delta$ $142.5,138.5,135.5,131.4,129.1,128.9,126.8,126.3,125.6,124.2,122.5,84.6,25.0,24.9 .{ }^{11} \mathrm{~B}$ NMR $\left(160 \mathrm{MHz}, \mathrm{CDCl}_{3}\right) \delta$ 29.48. HRMS (ASAP) $m / z$ : $[\mathrm{M}+\mathrm{H}]^{+}$Calcd for $\mathrm{C}_{18} \mathrm{H}_{19}{ }^{10} \mathrm{BO}_{2}{ }^{34} \mathrm{~S}$ 311.1193; Found 311.1197.

Diester 14b. Sparged toluene $(7 \mathrm{~mL})$ and water $(0.1 \mathrm{~mL})$ were added to an oven-dried flask containing 12b $(0.831 \mathrm{~g}, 2.68 \mathrm{mmol})$, ethyl 2,5-dibromoterephthalate $(0.460 \mathrm{~g}, 1.22 \mathrm{mmol})$, $\mathrm{Pd}(\mathrm{OAc})_{2}(0.0109 \mathrm{~g}, 0.0487 \mathrm{mmol})$, SPhos $(0.0399 \mathrm{~g}, 0.0974 \mathrm{mmol})$, and $\mathrm{K}_{3} \mathrm{PO}_{4}(0.775 \mathrm{~g}, 3.65$ $\mathrm{mmol}$ ) and refluxed overnight in a sand bath. Solids appeared as the reaction was cooled and quenched with water. This mixture was extracted with $\mathrm{DCM}$, dried $\left(\mathrm{MgSO}_{4}\right)$, and concentrated. The crude product was recrystallized from toluene to give $14 \mathrm{~b}(0.572 \mathrm{~g}, 80 \%)$ as a yellow solid. ${ }^{1} \mathrm{H}$ NMR $\left(500 \mathrm{MHz}, \mathrm{CDCl}_{3}\right) \delta 8.13(\mathrm{~d}, J=8.1 \mathrm{~Hz}, 1 \mathrm{H}), 8.03(\mathrm{~s}, 1 \mathrm{H}), 7.95(\mathrm{~d}, J=8.1 \mathrm{~Hz}, 1 \mathrm{H})$, 7.83-7.75 (m, 2H), 7.60 (t, $J=7.5 \mathrm{~Hz}, 1 \mathrm{H}), 7.54$ (t, $J=7.5 \mathrm{~Hz}, 1 \mathrm{H}), 7.48$ (s, 1H), 4.25 (q, $J=7.1$ $\mathrm{Hz}, 2 \mathrm{H}), 1.09$ (t, $J=7.1 \mathrm{~Hz}, 3 \mathrm{H}) .{ }^{13} \mathrm{C}$ NMR $\left(126 \mathrm{MHz}, \mathrm{CDCl}_{3}\right) \delta 167.7,139.8,138.4,137.8,134.5$, 134.1, 132.5, 131.1, 129.1, 128.9, 126.9, 126.0, 125.9, 125.1, 123.8, 122.2, 62.0, 14.0. HRMS (ASAP) $m / z$ : $[\mathrm{M}+\mathrm{H}]^{+}$Calcd for $\mathrm{C}_{36} \mathrm{H}_{27} \mathrm{O}_{4} \mathrm{~S}_{2}$ 587.1351; Found 587.1353. 
Dione 16b. A mixture of 14b (0.493 g, $0.840 \mathrm{mmol})$, EtOH (104 mL), $\mathrm{H}_{2} \mathrm{O}(26 \mathrm{~mL})$, and $\mathrm{KOH}(0.471 \mathrm{~g}, 8.40 \mathrm{mmol})$ was refluxed for ca. $24 \mathrm{~h}$. The reaction was concentrated to remove the $\mathrm{EtOH}$ and the resulting aqueous solution was acidified by dropwise addition of aqueous $10 \%$ $\mathrm{HCl}$. The resulting precipitate was collected, washed with $\mathrm{H}_{2} \mathrm{O}$, and dried overnight in an oven to yield a bright yellow solid. To a solution of the diacid $(0.446 \mathrm{~g}, 0.840 \mathrm{mmol})$ in DCM $(50 \mathrm{~mL})$, oxalyl chloride $(0.28 \mathrm{~mL}, 3.36 \mathrm{mmol})$ and DMF $(0.130 \mathrm{~mL}, 1.68 \mathrm{mmol})$ was added. The reaction mixture went from yellow to red and was stirred at room temperature overnight. After the DCM was removed under reduced pressure, solid $\mathrm{AlCl}_{3}(0.560 \mathrm{~g}, 4.20 \mathrm{mmol})$ was added to the crude acid chloride and the mixture was dissolved in DCM $(50 \mathrm{~mL})$. The black reaction mixture was stirred overnight, and then the mixture was poured over $\mathrm{HCl}(3 \mathrm{M})$ at $0{ }^{\circ} \mathrm{C}$. The precipitated dione was filtered, washed with water, DCM, and acetone. The resulting green solid was too poorly soluble to obtain NMR spectra (0.398 g, 96\%). HRMS (ASAP) $m / z$ : $[\mathrm{M}+\mathrm{H}]^{+}$Calcd for $\mathrm{C}_{32} \mathrm{H}_{15} \mathrm{O}_{2} \mathrm{~S}_{2}$ 495.0513; Found 495.0504.

IDNT 8. A flame dried flask containing dry THF $(5 \mathrm{~mL})$ and bromomesitylene $(0.464 \mathrm{~mL}$, $3.033 \mathrm{mmol})$ was cooled to $-78{ }^{\circ} \mathrm{C}$ for $\sim 10$ minutes, then $n$-BuLi $(1.8 \mathrm{~mL}, 1.6 \mathrm{M}, 2.88 \mathrm{mmol})$ was added dropwise. The reaction was stirred for 30 minutes and added to a solution of $\mathbf{1 6 b}(0.150 \mathrm{~g}$, $0.3033 \mathrm{mmol})$ in dry THF $(8 \mathrm{~mL})$ at $-78{ }^{\circ} \mathrm{C}$. After warming the solution to room temperature overnight, the reaction was quenched with $5 \% \mathrm{NH}_{4} \mathrm{Cl}$ soln and extracted with DCM. The organic phase was washed with brine, dried over $\mathrm{MgSO}_{4}$, and concentrated under to give the crude diol as a reddish-yellow solid.

Under $\mathrm{N}_{2}$ the diol $(0.212 \mathrm{~g}, 0.289 \mathrm{mmol})$ and $\mathrm{SnCl}_{2}(0.219 \mathrm{~g}, 1.16 \mathrm{mmol})$ were dissolved in dry toluene $(15 \mathrm{~mL})$ and heated to $70{ }^{\circ} \mathrm{C}$ in a sand bath. The solution became a green/teal blue color and upon completion $(\sim 4 \mathrm{~h})$, the mixture was filtered through celite eluting with DCM, and the filtrate was concentrated. The crude product was recrystallized from $\mathrm{CHCl}_{3} / \mathrm{MeCN}$ to yield a dark purple solid (0.0951 g, 47\%). ${ }^{1} \mathrm{H}$ NMR $\left(500 \mathrm{MHz}, \mathrm{CDCl}_{3}\right) \delta 7.82(\mathrm{~d}, J=8.3 \mathrm{~Hz}, 1 \mathrm{H}), 7.74$ $(\mathrm{d}, J=8.1 \mathrm{~Hz}, 1 \mathrm{H}), 7.46$ (t, $J=7.6 \mathrm{~Hz}, 1 \mathrm{H}), 7.40-7.35(\mathrm{~m}, 2 \mathrm{H}), 7.04$ (s, 2H), 6.67 (d, $J=8.6 \mathrm{~Hz}$, $1 \mathrm{H}), 6.16(\mathrm{~s}, 1 \mathrm{H}), 2.42(\mathrm{~s}, 3 \mathrm{H}), 2.37$ (s, 6H). ${ }^{13} \mathrm{C} \mathrm{NMR}\left(126 \mathrm{MHz}, \mathrm{CDCl}_{3}\right) \delta$ 138.1, 136.8, 131.4, 131.0, 131.0, 130.1, 130.0, 129.0, 128.92, 128.90, 128.5, 126.9, 126.9, 126.5, 126.43, 126.42, 125.4, 125.2, 122.9, 119.5, 29.9, 21.4, 20.7. HRMS (ASAP) $m / z$ : $[\mathrm{M}+\mathrm{H}]^{+}$Calcd for $\mathrm{C}_{50} \mathrm{H}_{37} \mathrm{~S}_{2}$ 701.2337; Found 701.2337. UV-vis $\left(\mathrm{CH}_{2} \mathrm{Cl}_{2}\right) \lambda_{\max }(\varepsilon) 294(25,500), 396(70,800), 611(31,600)$ $\mathrm{nm}$. 
Electrochemical Data. All electrochemical experiments were conducted with traditional 3electrode geometry using a Biologic SP-50 potentiostat. Electrolyte solutions (0.1 M) were prepared from anhydrous, degassed HPLC grade $\mathrm{CH}_{2} \mathrm{Cl}_{2}$ and anhydrous $\mathrm{Bu}_{4} \mathrm{NPF}_{6}$. The working electrode was a glassy carbon electrode (3-mm diameter), with a Pt-coil counter electrode and an $\mathrm{Ag}$ wire pseudo reference. The ferrocene/ferrocenium $(\mathrm{Fc} / \mathrm{Fc}+)$ couple was used as an internal standard following each experiment. Potential values were re-referenced to SCE using a value of 0.46 (V vs. SCE) for the $\mathrm{Fc} / \mathrm{Fc}+$ couple in $\mathrm{CH}_{2} \mathrm{Cl}_{2}$. LUMO and $\mathrm{HOMO}$ levels were approximated using $\mathrm{SCE}=-4.68 \mathrm{eV}$ vs. vacuum. $\mathrm{CV}$ experiments were conducted in a three-neck flask that had been evacuated and backfilled with $\mathrm{N}_{2}$ for three cycles using standard Schlenk-line technique. Voltammograms were recorded at a sweep rate of $50 \mathrm{mV} \mathrm{s}^{-1}$. $\mathrm{E}_{1 / 2}$ values were calculated assuming $\mathrm{E}_{1 / 2} \approx \mathrm{E}_{\mathrm{o}}{ }^{\prime}=\left(\mathrm{E}_{\text {anodic }}+\mathrm{E}_{\text {cathodic }}\right) / 2$ based on these observations for reversible couples; for irreversible couples, the $\mathrm{E}_{\mathrm{o}}$ ' value is estimated as the potential at peak current. Analyte concentrations were ca. 1-5 mM. 


\section{X-ray Crystallography Details}

General. X-ray quality crystals of IDNT 4 were obtained by dissolving the molecule in $\mathrm{CDCl}_{3}$ in an NMR tube and then slowly layering the solution with $\mathrm{MeCN}$, which was allowed to diffuse at $-20^{\circ} \mathrm{C}$. Diffraction intensities for 4 were collected at $173 \mathrm{~K}$ on a Bruker Apex2 CCD diffractometer using $\mathrm{CuK} \alpha$ radiation, $\lambda=1.54178 \AA$. Space group was determined based on systematic absences. Absorption corrections were applied by SADABS. ${ }^{8}$ Structure was solved by direct methods and Fourier techniques and refined on $F^{2}$ using full matrix least-squares procedures. All non-H atoms were refined with anisotropic thermal parameters. $\mathrm{H}$ atoms were refined in calculated positions in a rigid group model. The crystal structure includes $\mathrm{CH}_{3} \mathrm{CN}$ solvent molecules that were highly disordered over several positions in cavities in the packing of the main molecules. These disordered solvent molecules were treated by SQUEEZE. ${ }^{9}$ The corrections of the X-ray data by SQUEEZE are 112 electron/cell; the required value is 88 electron/cell for four $\mathrm{CH}_{3} \mathrm{CN}$ molecules in 4. All calculations were performed by the Bruker SHELXL-2014 package. ${ }^{10}$

Crystallographic Data for 4: $\mathrm{C}_{54} \mathrm{H}_{42} \mathrm{~N}_{2} \mathrm{~S}_{2}, \mathrm{M}=783.01,0.15 \times 0.13 \times 0.06 \mathrm{~mm}, \mathrm{~T}=173(2)$ $\mathrm{K}$, Monoclinic, space group $P 2{ }_{1} / c, a=16.8569(9) \AA, b=13.7634(7) \AA, c=9.3020(4) \AA, \beta=$ 103.027(3) $)^{\circ} V=2102.60(18) \AA^{3}, Z=2, D_{\mathrm{c}}=1.237 \mathrm{Mg} / \mathrm{m}^{3}, \mu(\mathrm{Cu})=1.443 \mathrm{~mm}^{-1}, F(000)=824$, $2 \theta_{\max }=133.92^{\circ}, 10253$ reflections, 3523 independent reflections $\left[\mathrm{R}_{\mathrm{int}}=0.0357\right], \mathrm{R} 1=0.0717$, $\mathrm{WR} 2=0.2035$ and $\mathrm{GOF}=1.004$ for 3523 reflections (235 parameters) with $\mathrm{I}>2 \sigma(\mathrm{I}), \mathrm{R} 1=0.0802$, $\mathrm{wR} 2=0.2105$ and $\mathrm{GOF}=1.004$ for all reflections, $\max / \mathrm{min}$ residual electron density $+0.624 /$ $-0.356 \mathrm{e} \AA^{-3}$. CCDC 2076855.

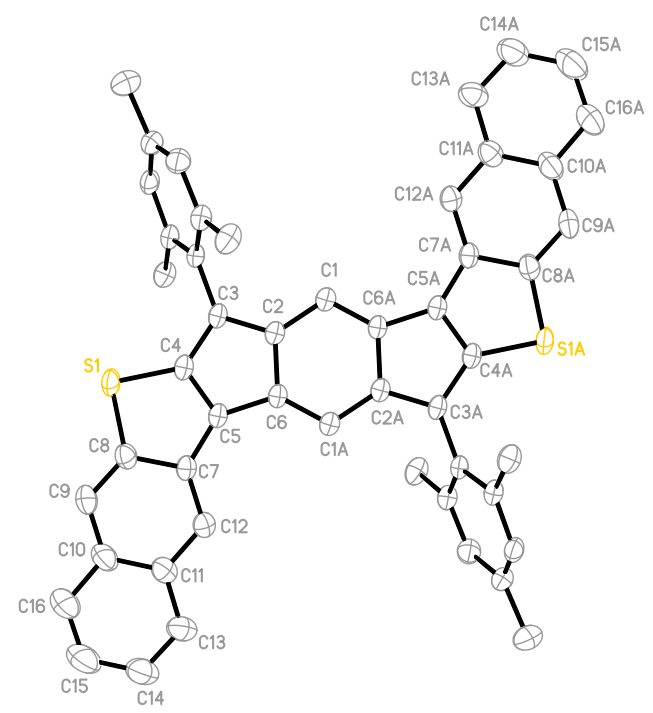

Figure S5. Molecular structure of IDNT 4; ellipsoids drawn at the 50\% probability level. 


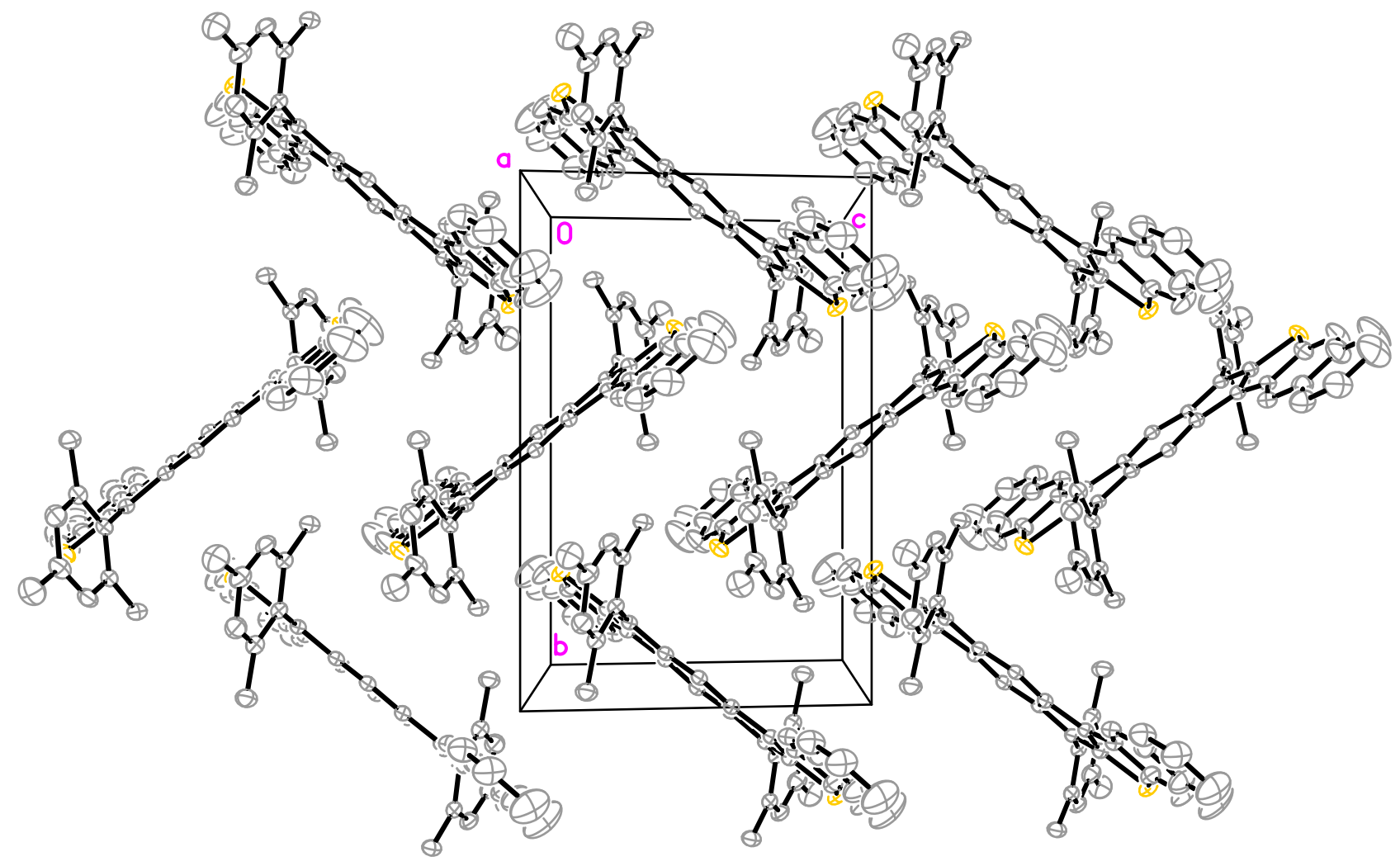

Figure S6. Molecular packing of IDNT 4; disordered $\mathrm{CH}_{3} \mathrm{CN}$ solvent molecules not shown. 


\section{Computational Details}

All calculations were performed using Gaussian 09. ${ }^{11}$ Geometries and TD-DFT calculations on simplified structures $4^{\prime}, \mathbf{5}^{\prime}, \mathbf{7}^{\prime}$, and $\mathbf{8}^{\prime}$ ' were optimized using RB3LYP/G-31++G** level of theory and all structures were verified as global minima by the absence of imaginary frequencies. All NICS-XY scans used the Aroma package ${ }^{12}$ with the RB3LYP/G-31++G** level of theory. NBO calculations were performed at the same level of theory using the NBO 3.1 program, ${ }^{13}$ as implemented by Gaussian 09.

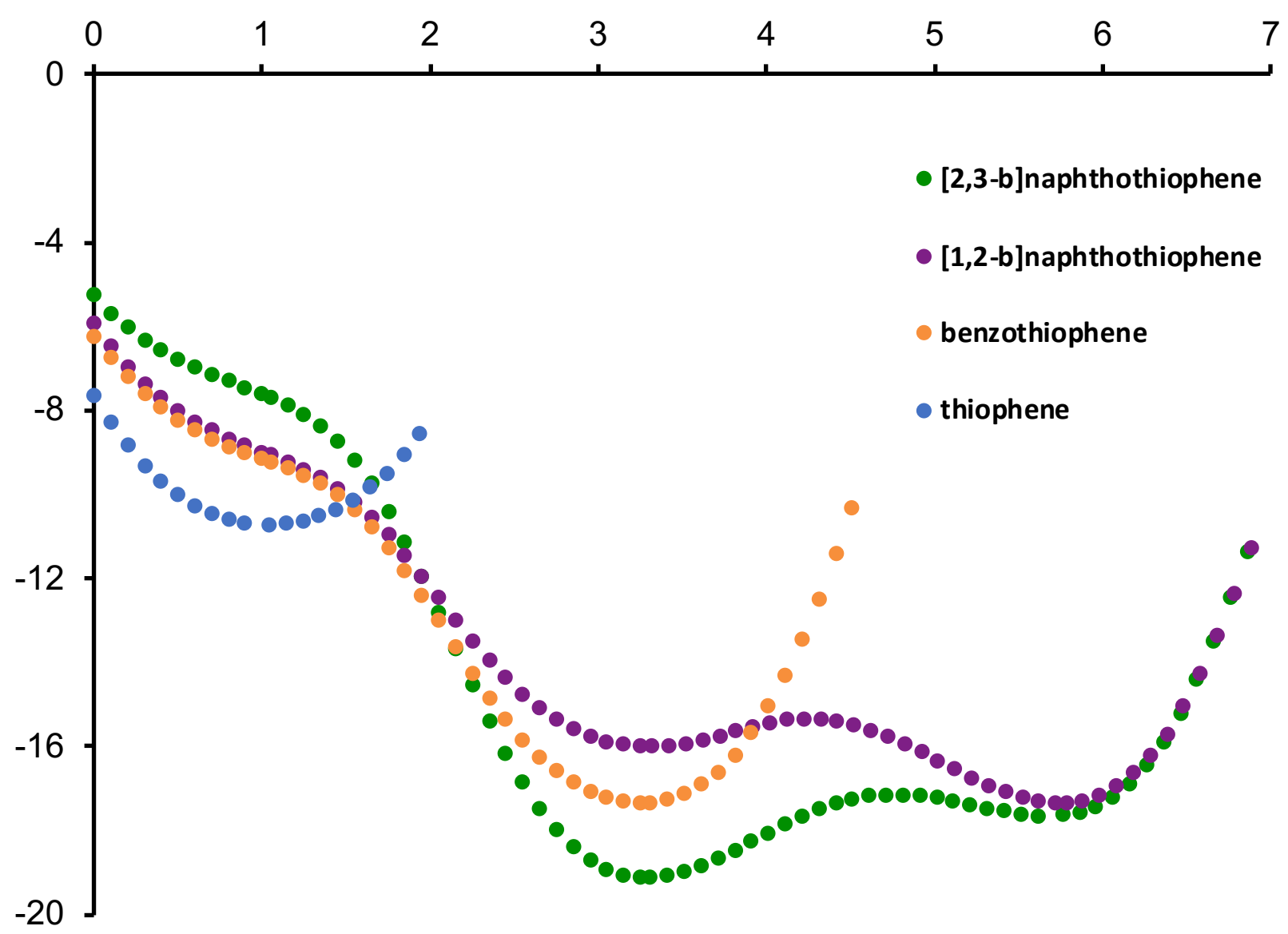

Figure S7. NICS-XY scans of thiophene and its benzo- and naphtho- homologues, in increasing order of thiophene aromaticity, which shows that the thiophene unit in naphtho[2,3-b]thiophene is the least aromatic of the four heterocycles. 

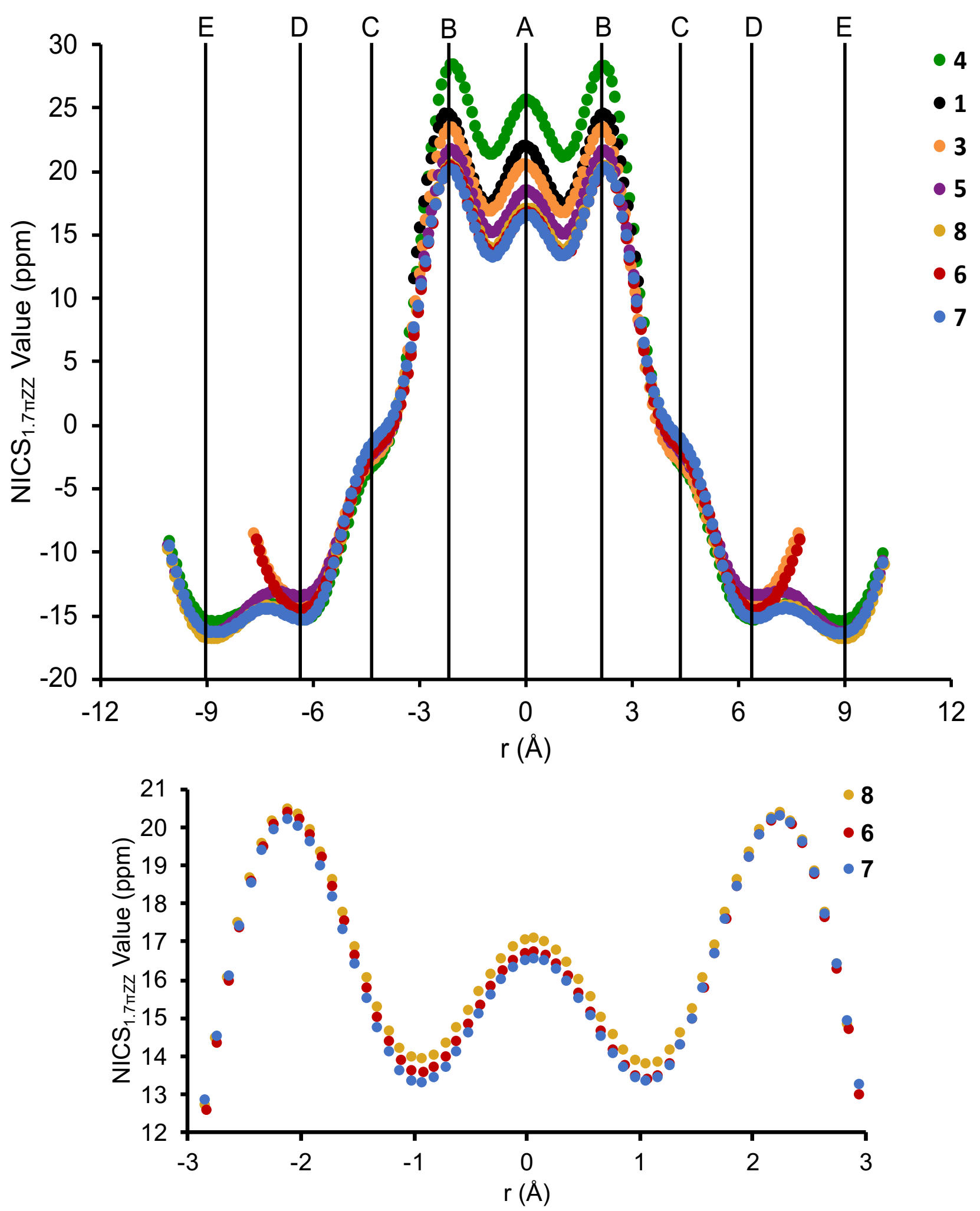

Figure S8. (top) Full-page image of the NICS-XY scans in descending order of paratropicity strength: 4 (green), 1 (black), 3 (orange), 5 (purple), 8 (gold), 6 (red), and 7 (blue). (bottom) Expanded region of the $s$-indacene core for compounds $\mathbf{6}-\mathbf{8}$. 


\section{Calculated Structures}

\section{syn-IDNT 4'}

Zero-point correction $=0.369194($ Hartree/Particle $)$

Thermal correction to Energy $=0.393232$

Thermal correction to Enthalpy $=0.394176$

Thermal correction to Gibbs Free Energy $=0.315145$

Sum of electronic and zero-point Energies = -2025.387503

Sum of electronic and thermal Energies $=-2025.363465$

Sum of electronic and thermal Enthalpies $=-2025.362521$

Sum of electronic and thermal Free Energies $=-2025.441552$

C - $1.4010910000-0.20812900000 .0000060000$

C -0.94841000001 .08633200000 .0000090000$

C 0.45584900001 .31812600000 .0000020000

C $1.17124500002 .5178210000-0.0000050000$

C $2.55653500002 .1882120000-0.0000020000$

C $2.73067100000 .8057640000-0.0000030000$

C $4.10548600000 .4110720000-0.0000010000$

C $4.6861600000-0.8509460000-0.0000020000$

C $6.0871910000-1.0029610000-0.0000010000$

C $6.7041460000-2.2872740000-0.0000010000$

C $8.0692580000-2.41658400000 .0000000000$

C $8.8970390000-1.26473900000 .0000020000$

C $8.3396410000-0.01029900000 .0000020000$

C 6.92895600000 .16394600000 .0000010000

C 6.33662200001 .44979100000 .0000010000

C 4.96825000001 .56765600000 .0000000000

S 4.05806900003 .09089400000 .0000000000

C $1.40109100000 .2081290000-0.0000060000$

C $0.9484100000-1.0863320000-0.0000090000$

C $-0.4558490000-1.3181260000-0.0000030000$

C - $1.1712450000-2.51782100000 .0000040000$

C - $2.5565350000-2.18821200000 .0000020000$

C -2.7306710000 -0.8057640000 0.0000030000 
C $-4.1054860000-0.41107200000 .0000010000$

C -4.68616000000 .85094600000 .0000020000$

C -6.0871910000 1.00296100000 .0000010000

C -6.7041460000 2.2872740000 0.0000010000

C -8.06925800002 .41658400000 .0000000000$

C -8.8970390000 $1.2647390000-0.0000020000$

C $-8.33964100000 .0102990000-0.0000020000$

C $-6.9289560000-0.1639460000-0.0000010000$

C -6.3366220000 - $1.4497910000-0.0000010000$

C $-4.9682500000-1.56765600000 .0000000000$

S - $-4.0580690000-3.09089400000 .0000000000$

$\mathrm{H}-1.63007500001 .93035600000 .0000100000$

H $0.74811900003 .5130420000-0.0000050000$

H $4.0633310000-1.7382360000-0.0000030000$

H $6.0700760000-3.1678660000-0.0000020000$

H $8.5225160000-3.40137300000 .0000000000$

H $9.9749680000-1.38019600000 .0000030000$

H 8.97317400000 .87060900000 .0000040000

H 6.97401700002 .32728000000 .0000020000

H $1.6300750000-1.9303560000-0.0000100000$

H - $0.7481190000-3.51304200000 .0000030000$

H -4.06333100001 .73823600000 .0000030000$

H -6.0700760000 3.16786600000 .0000020000

H -8.5225160000 3.40137300000 .0000000000

H -9.9749680000 $1.3801960000-0.0000030000$

H -8.9731740000 -0.8706090000 -0.0000030000

H -6.9740170000 -2.3272800000 - 0.0000020000

\section{syn-IDNT 5'}

Zero-point correction $=0.369737$ (Hartree/Particle $)$

Thermal correction to Energy $=0.393788$

Thermal correction to Enthalpy $=0.394732$

Thermal correction to Gibbs Free Energy $=0.315764$

Sum of electronic and zero-point Energies $=-2025.394524$ 
Sum of electronic and thermal Energies $=-2025.370473$

Sum of electronic and thermal Enthalpies $=-2025.369529$

Sum of electronic and thermal Free Energies $=-2025.448497$

C 1.41523900000 .06523600000 .0000040000

C 0.72286200001 .24814500000 .0000070000

C -0.70009900001 .20752500000 .0000010000$

C - $1.62979700002 .2491670000-0.0000080000$

C - $2.92595200001 .6604450000-0.0000040000$

C $-2.83563400000 .2668390000-0.0000030000$

C -4.1098590000 -0.3700190000 -0.0000010000

C -4.4350640000 - $1.7573910000-0.0000010000$

C -5.7413760000 -2.1573590000 0.0000000000

C -6.8153780000 - 1.21434000000 .0000010000

C -6.52841900000 .18832300000 .0000010000$

C -7.6068610000 1.1074860000 0.0000010000

C -8.9107680000 0.6658030000 0.0000020000

C -9.1963520000 -0.7159250000 0.0000020000

C -8.1673970000 -1.6318030000 0.0000020000

C -5.15987900000 .57390100000 .0000000000$

S -4.5714170000 2.23524800000.0000000000

C - $1.4152390000-0.0652360000-0.0000050000$

C - $0.7228620000-1.2481450000-0.0000070000$

C $0.7000990000-1.2075250000-0.0000030000$

C $1.6297970000-2.24916700000 .0000010000$

C $2.9259520000-1.66044500000 .0000010000$

C $2.8356340000-0.26683900000 .0000010000$

C 4.10985900000 .37001900000 .0000010000

C 4.43506400001 .75739100000 .0000020000

C 5.74137600002 .15735900000 .0000010000

C 6.81537800001 .21434000000 .0000000000

C $6.5284190000-0.18832300000 .0000000000$

C $7.6068610000-1.10748600000 .0000000000$

C $8.9107680000-0.6658030000-0.0000010000$ 
C 9.19635200000 .71592500000 .0000000000

C 8.16739700001 .63180300000 .0000000000

C $5.1598790000-0.57390100000 .0000000000$

S $4.5714170000-2.23524800000 .0000010000$

H 1.22995200002 .20731800000 .0000080000

H - $1.40342400003 .3065820000-0.0000090000$

H -3.6398340000 - $2.4928030000-0.0000010000$

H -5.9860340000 -3.2141450000 0.0000000000

$\mathrm{H}-7.39879100002 .17182100000 .0000010000$

H -9.72351200001 .38318700000 .0000030000$

H - $10.2263750000-1.05350300000 .0000030000$

H $-8.3828230000-2.69527500000 .0000020000$

H - $1.2299520000-2.2073180000-0.0000080000$

H $1.4034240000-3.30658200000 .0000010000$

H 3.63983400002 .49280300000 .0000020000

H 5.98603400003 .21414500000 .0000020000

H $7.3987910000-2.1718200000-0.0000010000$

H $9.7235120000-1.3831870000-0.0000010000$

H $10.22637500001 .0535030000-0.0000010000$

H 8.38282300002 .69527500000 .0000010000

\section{anti-IDNT 7,}

Zero-point correction $=0.368752$ (Hartree/Particle)

Thermal correction to Energy $=0.392842$

Thermal correction to Enthalpy $=0.393787$

Thermal correction to Gibbs Free Energy $=0.314804$

Sum of electronic and zero-point Energies $=-2025.392138$

Sum of electronic and thermal Energies $=-2025.368048$

Sum of electronic and thermal Enthalpies $=-2025.367104$

Sum of electronic and thermal Free Energies $=-2025.446086$

C 1.27005400000 .58999100000 .0000080000

C 2.67300200000 .81616500000 .0000050000

S 3.73491900002 .18751300000 .0000030000 

C 5.16276600001 .11235300000 .0000000000
C $6.46957200001 .5248990000-0.0000030000$
C $7.50573400000 .5548240000-0.0000040000$
C $8.87650800000 .9245520000-0.0000070000$
C $9.8658800000-0.0291660000-0.0000070000$
C $9.5301720000-1.4045690000-0.0000050000$
C $8.2138860000-1.7970640000-0.0000010000$
C $7.1630040000-0.8394600000-0.0000010000$
C $5.8008410000-1.22447300000 .0000030000$
C $4.7963950000-0.27630200000 .0000030000$
C $3.3600690000-0.42727800000 .0000060000$
C $2.4024080000-1.45393800000 .0000120000$
C $1.1128380000-0.85917200000 .0000040000$
C -0.1621010000 -1.4332240000 -0.0000020000
C - $1.2700540000-0.5899910000-0.0000020000$
C -2.6730020000 -0.8161650000-0.0000010000
S -3.7349190000 -2.1875130000-0.0000010000
C -5.1627660000 -1.1123530000 -0.0000010000
C -6.4695720000 -1.5248990000 -0.0000010000
C -7.5057340000 -0.5548240000 -0.0000010000
C -8.8765080000 -0.9245520000 -0.0000010000
C -9.8658800000 $0.0291660000-0.0000010000$
C -9.5301720000 $1.4045690000-0.0000020000$
C -8.2138860000 $1.7970640000-0.0000020000$
C $-7.16300400000 .8394600000-0.0000020000$
C $-5.80084100001 .2244730000-0.0000020000$
C $-4.79639500000 .2763020000-0.0000010000$
C $-3.36006900000 .4272780000-0.0000020000$
C - $2.40240800001 .4539380000-0.0000040000$
C - 1.11283800000 .85917200000 .0000030000
C 0.16210100001 .43322400000 .0000090000
H $6.72805700002 .5781980000-0.0000050000$
H $9.13246700001 .9790780000-0.0000090000$
H $10.90816700000 .2688980000-0.0000100000$ 
H $10.3187520000-2.1485700000-0.0000050000$

H $7.9570590000-2.85134600000 .0000010000$

H $5.5531010000-2.28084000000 .0000050000$

H $2.6003990000-2.51757300000 .0000150000$

H $-0.2792430000-2.5129200000-0.0000020000$

H $-6.7280570000-2.5781980000-0.0000010000$

H $-9.1324670000-1.9790780000-0.0000010000$

H - $10.9081670000-0.2688980000-0.0000010000$

$\mathrm{H}-10.31875200002 .1485700000-0.0000020000$

H -7.9570590000 $2.8513460000-0.0000020000$

H -5.5531010000 $2.2808400000-0.0000020000$

H -2.6003990000 $2.5175730000-0.0000050000$

H 0.27924300002 .51292000000 .0000090000

\section{anti-IDNT 8,}

Zero-point correction $=0.369502($ Hartree/Particle $)$

Thermal correction to Energy $=0.393586$

Thermal correction to Enthalpy $=0.394530$

Thermal correction to Gibbs Free Energy $=0.315494$

Sum of electronic and zero-point Energies $=-2025.394700$

Sum of electronic and thermal Energies $=-2025.370616$

Sum of electronic and thermal Enthalpies $=-2025.369672$

Sum of electronic and thermal Free Energies $=-2025.448708$

C -1.35597600000 .37795700000 .0000000000$

C -0.41945800001 .38307300000 .0000000000$

C 0.95389700001 .02933300000 .0000000000

C 2.10076400001 .82594900000 .0000000000

C 3.24634200000 .96960200000 .0000000000

C $2.7974340000-0.35651500000 .0000000000$

S $4.0926870000-1.50244000000 .0000000000$

C $5.2864540000-0.18819600000 .0000000000$

C 4.67866200001 .07573400000 .0000000000

C 5.50077300002 .23422900000 .0000000000 
C 6.86395600002 .10709000000 .0000000000

C 7.49671200000 .82856300000 .0000000000

C $6.6959070000-0.35976700000 .0000000000$

C $7.3426270000-1.62126300000 .0000000000$

C $8.7158310000-1.70943700000 .0000000000$

C $9.5082000000-0.54066800000 .0000000000$

C 8.90740800000 .69747900000 .0000000000

C $1.3559760000-0.37795700000 .0000000000$

C $0.4194580000-1.38307300000 .0000000000$

C $-0.9538970000-1.02933300000 .0000000000$

C - $2.1007640000-1.8259490000-0.0000010000$

C $-3.2463420000-0.96960200000 .0000000000$

C -2.79743400000 .35651500000 .0000000000$

S -4.09268700001 .50244000000 .0000000000$

C -5.28645400000 .18819600000 .0000000000$

C $-4.6786620000-1.07573400000 .0000000000$

C $-5.5007730000-2.23422900000 .0000000000$

C $-6.8639560000-2.10709000000 .0000000000$

C $-7.4967120000-0.82856300000 .0000000000$

C -6.69590700000 .35976700000 .0000000000$

C - 7.34262700001 .62126300000 .0000000000

C -8.71583100001 .70943700000 .0000000000$

C -9.50820000000 .54066800000 .0000000000$

C $-8.9074080000-0.69747900000 .0000000000$

$\mathrm{H}-0.71044700002 .42924100000 .0000000000$

H 2.1141960000 2.9080450000 0.0000000000

H 5.04093500003 .21605300000 .0000000000

H 7.4917100000 2.9917520000 0.0000000000

H $6.7447650000-2.52619100000 .0000000000$

H $9.1937090000-2.68257200000 .0000000000$

H $10.5890250000-0.62253300000 .0000000000$

H 9.5121290000 1.59848500000 .0000000000

H $0.7104470000-2.42924100000 .0000000000$

H -2.1141960000 -2.9080450000 -0.0000010000 
H -5.0409350000 -3.2160530000 0.0000000000

H -7.4917100000 -2.9917520000 0.0000000000

H -6.7447650000 2.5261910000 0.0000000000

H -9.19370900002 .68257200000 .0000010000$

H - 10.58902500000 .62253300000 .0000000000

H $-9.5121290000-1.59848500000 .0000000000$

\section{Thiophene}

Zero-point correction $=0.066384$ (Hartree/Particle)

Thermal correction to Energy $=0.070465$

Thermal correction to Enthalpy $=0.071409$

Thermal correction to Gibbs Free Energy $=0.039801$

Sum of electronic and zero-point Energies $=-553.006874$

Sum of electronic and thermal Energies $=-553.002793$

Sum of electronic and thermal Enthalpies $=-553.001849$

Sum of electronic and thermal Free Energies $=-553.033456$

C $0.0000000000-1.2412410000-0.0113720000$

C $0.0000000000-0.7138230000-1.2714080000$

C $0.00000000000 .7138230000-1.2714080000$

C $0.00000000001 .2412410000-0.0113720000$

S 0.00000000000 .00000000001 .1979210000

H $0.0000000000-2.27965200000 .2820080000$

H $0.0000000000-1.3184590000-2.1686950000$

H $0.00000000001 .3184590000-2.1686950000$

H 0.00000000002 .27965200000 .2820080000

\section{Benzothiophene}

Zero-point correction $=0.113549$ (Hartree/Particle)

Thermal correction to Energy $=0.120068$

Thermal correction to Enthalpy $=0.121013$

Thermal correction to Gibbs Free Energy $=0.082496$

Sum of electronic and zero-point Energies $=-706.644191$

Sum of electronic and thermal Energies $=-706.637671$ 
Sum of electronic and thermal Enthalpies $=-706.636727$

Sum of electronic and thermal Free Energies = -706.675244

C -0.01543100000 .85864400000 .0000000000$

C - 1.25552800001 .52117800000 .0000000000

C -2.42762200000 .78225200000 .0000000000$

C - $2.3912590000-0.62293800000 .0000000000$

C $-1.1811840000-1.30305600000 .0000000000$

C $0.0000000000-0.55674000000 .0000000000$

S $1.6454600000-1.16930200000 .0000000000$

C 2.2811960000 0.46067100000 .0000000000

C 1.31423700001 .41084900000 .0000000000

$\mathrm{H}-1.28814000002 .60531000000 .0000000000$

$\mathrm{H}-3.38485200001 .29087500000 .0000000000$

H -3.3188720000 -1.1837820000 0.0000000000

H - $1.1558420000-2.38652300000 .0000000000$

H 3.35131300000 .60480500000 .0000000000

H 1.52257900002 .47297800000 .0000000000

\section{Naphtho[1,2-b]thiophene}

Zero-point correction $=0.160091$ (Hartree/Particle)

Thermal correction to Energy $=0.169273$

Thermal correction to Enthalpy $=0.170217$

Thermal correction to Gibbs Free Energy $=0.125440$

Sum of electronic and zero-point Energies $=-860.276680$

Sum of electronic and thermal Energies $=-860.267498$

Sum of electronic and thermal Enthalpies $=-860.266554$

Sum of electronic and thermal Free Energies $=-860.311332$

C - 1.40666600000 .90706400000 .0000000000

C -0.71037100002 .15528400000 .0000000000$

C 0.65549400002 .21327100000 .0000000000

C 1.41733700001 .01120700000 .0000000000

C 2.84584300000 .86096400000 .0000000000 
C $3.2390810000-0.43843000000 .0000010000$

S $1.8934250000-1.54926800000 .0000000000$

C $0.7514900000-0.22079200000 .0000000000$

C $-0.6696670000-0.31939700000 .0000000000$

C $-1.3773460000-1.54555600000 .0000000000$

C $-2.7541380000-1.56556600000 .0000000000$

C $-3.4849650000-0.35851500000 .0000000000$

C -2.82198200000 .84806200000 .0000000000$

H - 1.29450000003 .06931400000 .0000000000

H 1.16754800003 .16924900000 .0000000000

H 3.53702000001 .69392100000 .0000000000

H $4.2445480000-0.83136700000 .0000010000$

H $-0.8244050000-2.47863500000 .0000000000$

H -3.2804460000 -2.5133510000 0.0000000000

H $-4.5686560000-0.38477300000 .0000000000$

H -3.3805780000 1.77835800000 .0000000000

\section{Naphtho[2,3-b]thiophene}

Zero-point correction $=0.159918($ Hartree/Particle $)$

Thermal correction to Energy $=0.169091$

Thermal correction to Enthalpy $=0.170035$

Thermal correction to Gibbs Free Energy $=0.125283$

Sum of electronic and zero-point Energies $=-860.272421$

Sum of electronic and thermal Energies $=-860.263248$

Sum of electronic and thermal Enthalpies $=-860.262304$

Sum of electronic and thermal Free Energies $=-860.307056$

C 1.28059200000 .74567800000 .0000000000

C 2.57173600001 .34786100000 .0000000000

C 3.70968100000 .58316300000 .0000000000

C $3.6205370000-0.83299300000 .0000000000$

C $2.3956670000-1.44998800000 .0000000000$

C $1.1916340000-0.69062200000 .0000000000$

C $-0.0786330000-1.31098600000 .0000000000$ 
C $-1.2116200000-0.52881000000 .0000000000$

C -1.14305200000 .90173400000 .0000000000$

C -2.4577920000 1.49763300000 .0000000000

C -3.45452800000 .58377900000 .0000010000$

S - $2.8874730000-1.07776500000 .0000000000$

C 0.09900300001 .51590700000 .0000000000

H 2.6390430000 2.4309240000 0.0000000000

H 4.68433600001 .05796300000 .0000000000

H $4.5279270000-1.42634300000 .0000000000$

H $2.3275190000-2.53297100000 .0000000000$

H - $0.1423910000-2.39357900000 .0000000000$

H -2.6288210000 2.5663360000 0.0000000000

H -4.51855500000 .76898900000 .0000010000$

H 0.17116000002 .59879800000 .0000000000

Table S1. TD-DFT calculations for model IDNT compounds 4', 5', 7', and ' $\mathbf{8}^{\prime}$. For computational efficiency, model compounds do not include mesityl groups.

\begin{tabular}{|l|l|l|l|}
\hline syn-IDNT 4' & \multicolumn{2}{|l|}{ Oscillator Strength } \\
\hline Excited State 1 & HOMO to LUMO & $1373.96 \mathrm{~nm}$ & $\mathrm{f}=0.0000$ \\
\hline Excited State 2 & HOMO-2 to LUMO & $716.82 \mathrm{~nm}$ & $\mathrm{f}=0.3343$ \\
\hline & HOMO-1 to LUMO & & \\
\hline Excited State 3 & HOMO-2 to LUMO & $586.80 \mathrm{~nm}$ & $\mathrm{f}=0.5076$ \\
\hline & HOMO-1 to LUMO & & \\
\hline & HOMO to LUMO+3 & & \\
\hline Excited State 4 & HOMO-3 to LUMO & $544.05 \mathrm{~nm}$ & $\mathrm{f}=0.0000$ \\
\hline Excited State 5 & HOMO-4 to LUMO & $422.41 \mathrm{~nm}$ & $\mathrm{f}=0.0000$ \\
\hline Excited State 6 & HOMO-5 to LUMO & $401.11 \mathrm{~nm}$ & $\mathrm{f}=0.0108$ \\
\hline & HOMO to LUMO+1 & & \\
\hline Excited State 7 & HOMO-6 to LUMO & $386.23 \mathrm{~nm}$ & $\mathrm{f}=0.0154$ \\
\hline & HOMO-5 to LUMO & & \\
\hline & HOMO to LUMO+1 & & \\
\hline Excited State 8 & HOMO-1 to LUMO+1 & $381.38 \mathrm{~nm}$ & $\mathrm{f}=0.0000$ \\
\hline & HOMO to LUMO+2 & & \\
\hline
\end{tabular}




\begin{tabular}{|l|l|l|l|}
\hline syn-IDNT 5' & & & Oscillator Strength \\
\hline Excited State 1 & HOMO to LUMO & $1070.21 \mathrm{~nm}$ & $\mathrm{f}=0.0000$ \\
\hline Excited State 2 & HOMO-1 to LUMO & $650.68 \mathrm{~nm}$ & $\mathrm{f}=0.9129$ \\
\hline & HOMO to LUMO+4 & & \\
\hline Excited State 3 & LUMO to HOMO-1 & & \\
\hline Excited State 4 & HOMO-2 to LUMO & $509.27 \mathrm{~nm}$ & $\mathrm{f}=0.0000$ \\
\hline Excited State 5 & HOMO-3 to LUMO & $505.69 \mathrm{~nm}$ & $\mathrm{f}=0.0078$ \\
\hline & HOMO-4 to LUMO & $400.90 \mathrm{~nm}$ & $\mathrm{f}=0.0481$ \\
\hline & HOMO to LUMO+1 & & \\
\hline & HOMO to LUMO+3 & & \\
\hline Excited State 6 & HOMO to LUMO+4 & & \\
\hline & HOMO-4 to LUMO & $377.12 \mathrm{~nm}$ & $\mathrm{f}=0.3298$ \\
\hline & HOMO-1 to LUMO+2 & & \\
\hline Excited State 7 & HOMO to LUMO+1 & & \\
\hline & HOMO-5 to LUMO & $377.12 \mathrm{~nm}$ & $\mathrm{f}=0.0000$ \\
\hline Excited State 8 & HOMO to LUMO+2 & & \\
\hline & HOMO-5 to LUMO & $371.08 \mathrm{~nm}$ & $\mathrm{f}=0.0000$ \\
\hline & HOMO-1 to LUMO+1 & & \\
\hline & HOMO-1 to LUMO+3 & & \\
\hline & HOMO to LUMO+2 & & \\
\hline & & & \\
\hline & & & \\
\hline & & & \\
\hline & & & \\
\hline & & & \\
\hline & HOMO & \\
\hline & & & \\
\hline & HOMO & \\
\hline
\end{tabular}

\begin{tabular}{|l|l|l|l|}
\hline anti-IDNT 7 & & & Oscillator Strength \\
\hline Excited State 1 & HOMO to LUMO & $1164.41 \mathrm{~nm}$ & $\mathrm{f}=0.0000$ \\
\hline Excited State 2 & HOMO-2 to LUMO & $660.16 \mathrm{~nm}$ & $\mathrm{f}=0.4469$ \\
\hline & HOMO-1 to LUMO & & \\
\hline & HOMO to LUMO+1 & & \\
\hline & LUMO to HOMO -1 & & \\
\hline Excited State 3 & HOMO-3 to LUMO & $512.85 \mathrm{~nm}$ & $\mathrm{f}=0.0000$ \\
\hline Excited State 4 & HOMO-2 to LUMO & $488.28 \mathrm{~nm}$ & $\mathrm{f}=0.0053$ \\
\hline & HOMO-1 to LUMO & & \\
\hline & HOMO to LUMO+1 & & \\
\hline Excited State 5 & HOMO-1 to LUMO+1 & $436.39 \mathrm{~nm}$ & $\mathrm{f}=0.0000$ \\
\hline
\end{tabular}




\begin{tabular}{|l|l|l|l|}
\hline Excited State 6 & HOMO-4 to LUMO & $421.06 \mathrm{~nm}$ & $\mathrm{f}=0.1152$ \\
\hline & HOMO to LUMO+1 & & \\
\hline Excited State 7 & HOMO-4 to LUMO & $401.25 \mathrm{~nm}$ & $\mathrm{f}=1.9063$ \\
\hline & HOMO-2 to LUMO & & \\
\hline & HOMO-1 to LUMO & & \\
\hline & HOMO-1 to LUMO+2 & & \\
\hline & HOMO to LUMO+1 & & \\
\hline Excited State 8 & HOMO to LUMO+3 & & \\
\hline & HOMO-5 to LUMO & $384.67 \mathrm{~nm}$ & $\mathrm{f}=0.0000$ \\
\hline & HOMO to LUMO+2 & & \\
\hline
\end{tabular}

\begin{tabular}{|l|l|l|l|}
\hline anti-IDNT 8 & & & Oscillator Strength \\
\hline Excited State 1 & HOMO to LUMO & $1088.23 \mathrm{~nm}$ & $\mathrm{f}=0.0000$ \\
\hline Excited State 2 & HOMO-1 to LUMO & $597.02 \mathrm{~nm}$ & $\mathrm{f}=0.4115$ \\
\hline & HOMO to LUMO+1 & & \\
\hline & LUMO to HOMO-1 & & \\
\hline Excited State 3 & HOMO-2 to LUMO & $514.80 \mathrm{~nm}$ & $\mathrm{f}=0.0054$ \\
\hline Excited State 4 & HOMO-3 to LUMO & $501.00 \mathrm{~nm}$ & $\mathrm{f}=0.0000$ \\
\hline Excited State 5 & HOMO-4 to LUMO & $410.20 \mathrm{~nm}$ & $\mathrm{f}=0.2565$ \\
\hline & HOMO to LUMO+2 & & \\
\hline Excited State 6 & HOMO-1 to LUMO+1 & $394.63 \mathrm{~nm}$ & $\mathrm{f}=0.0000$ \\
\hline & HOMO to LUMO+2 & & \\
\hline Excited State 7 & HOMO-4 to LUMO & $384.03 \mathrm{~nm}$ & $\mathrm{f}=1.3031$ \\
\hline & HOMO-1 to LUMO & & \\
\hline & HOMO to LUMO+1 & & \\
\hline & HOMO to LUMO+3 & & \\
\hline Excited State 8 & HOMO-5 to LUMO & $370.08 \mathrm{~nm}$ & \\
\hline & HOMO-1 to LUMO+1 & & \\
\hline & HOMO to LUMO+2 & & \\
\hline & & & \\
\hline
\end{tabular}




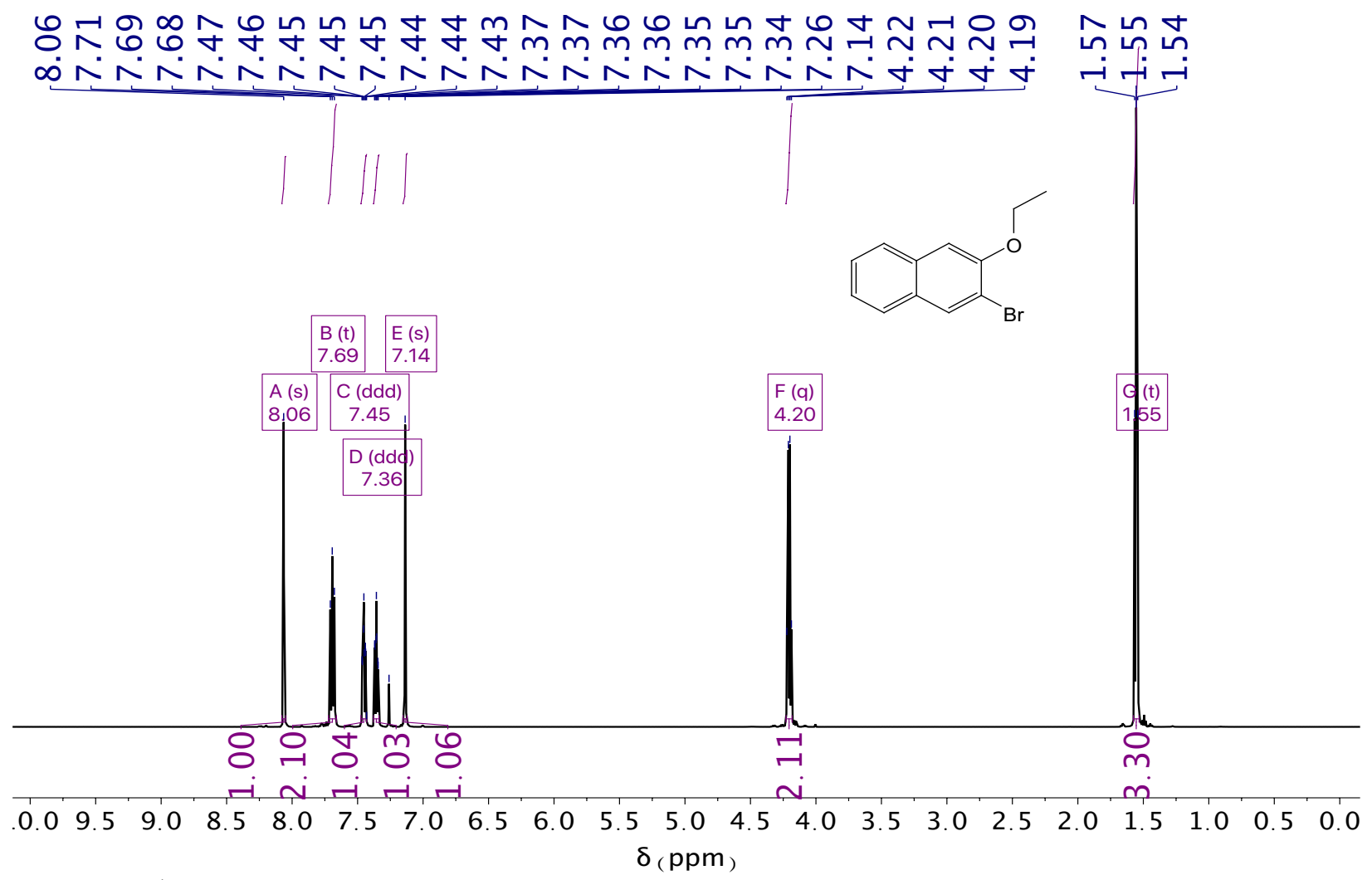

Figure S9. ${ }^{1} \mathrm{H}$ NMR spectrum $\left(\mathrm{CDCl}_{3}, 600 \mathrm{MHz}\right)$ of compound $\mathbf{S 2}$.

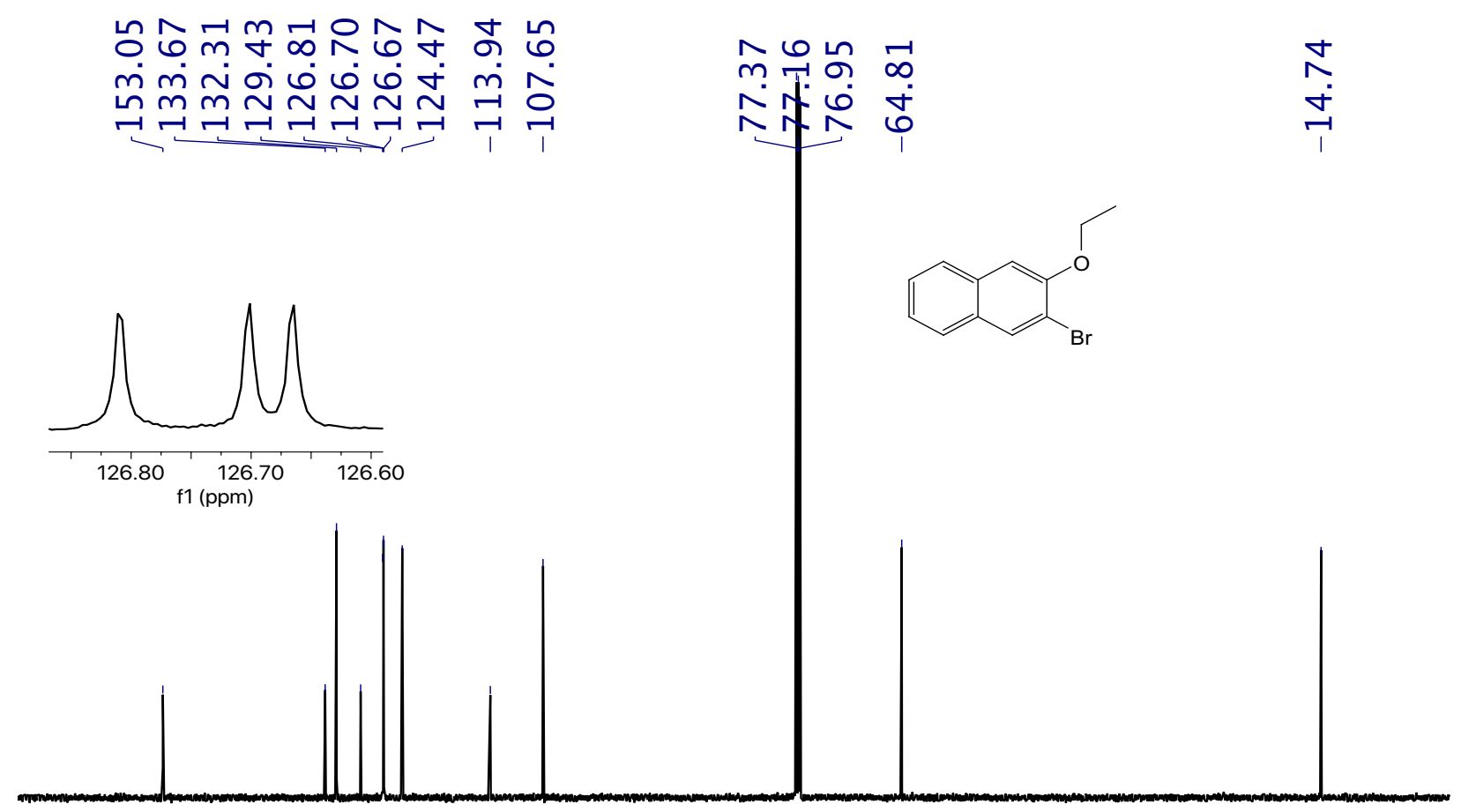

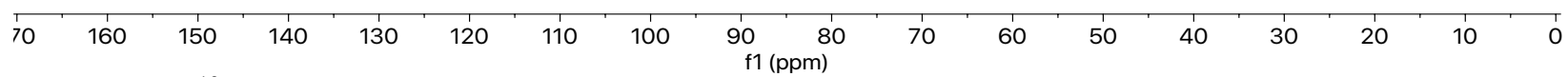

Figure S10. ${ }^{13} \mathrm{C}$ NMR spectrum $\left(\mathrm{CDCl}_{3}, 151 \mathrm{MHz}\right)$ of compound $\mathbf{S 2}$. 

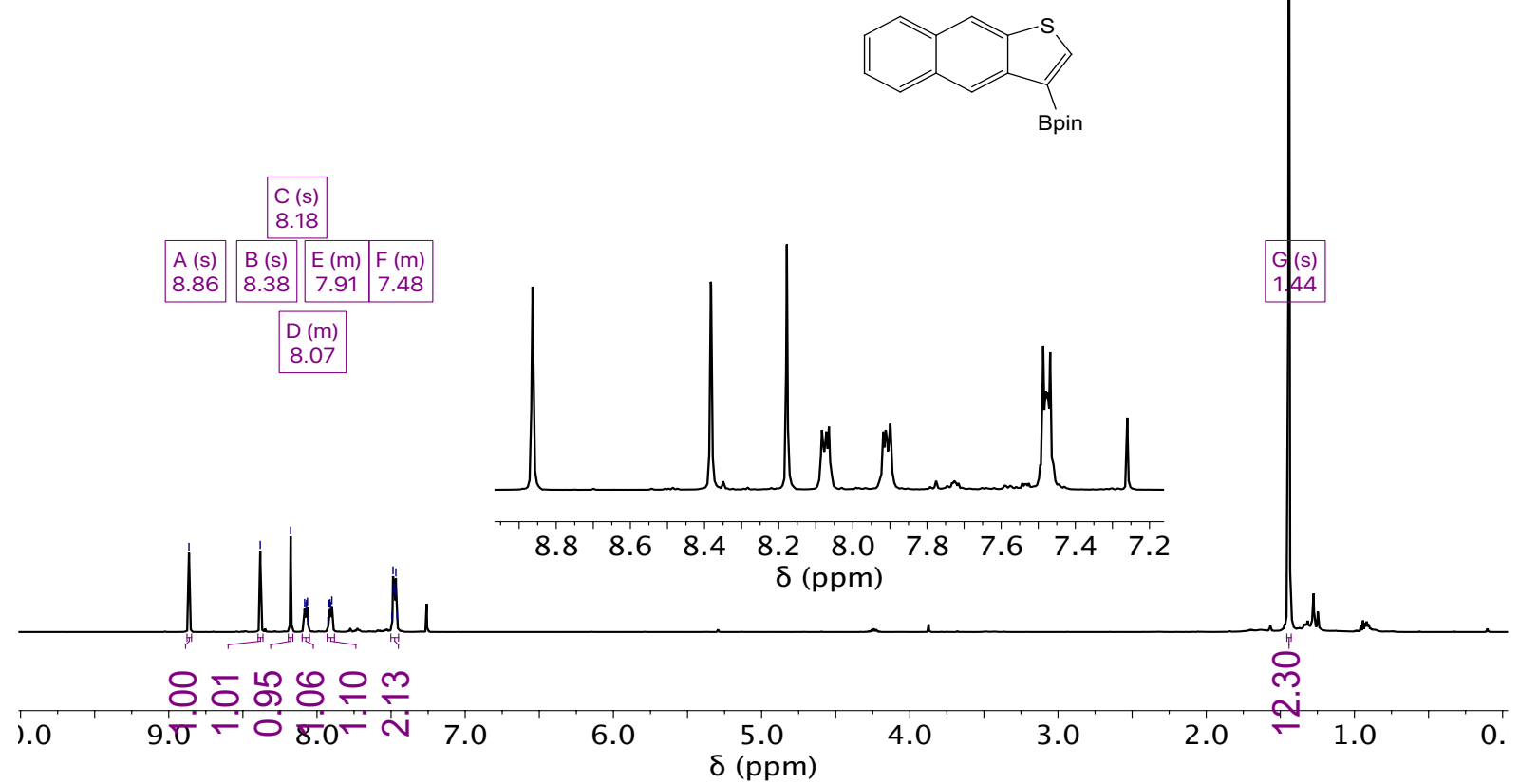

Figure S11. ${ }^{1} \mathrm{H}$ NMR spectrum $\left(\mathrm{CDCl}_{3}, 500 \mathrm{MHz}\right)$ of compound 11 .
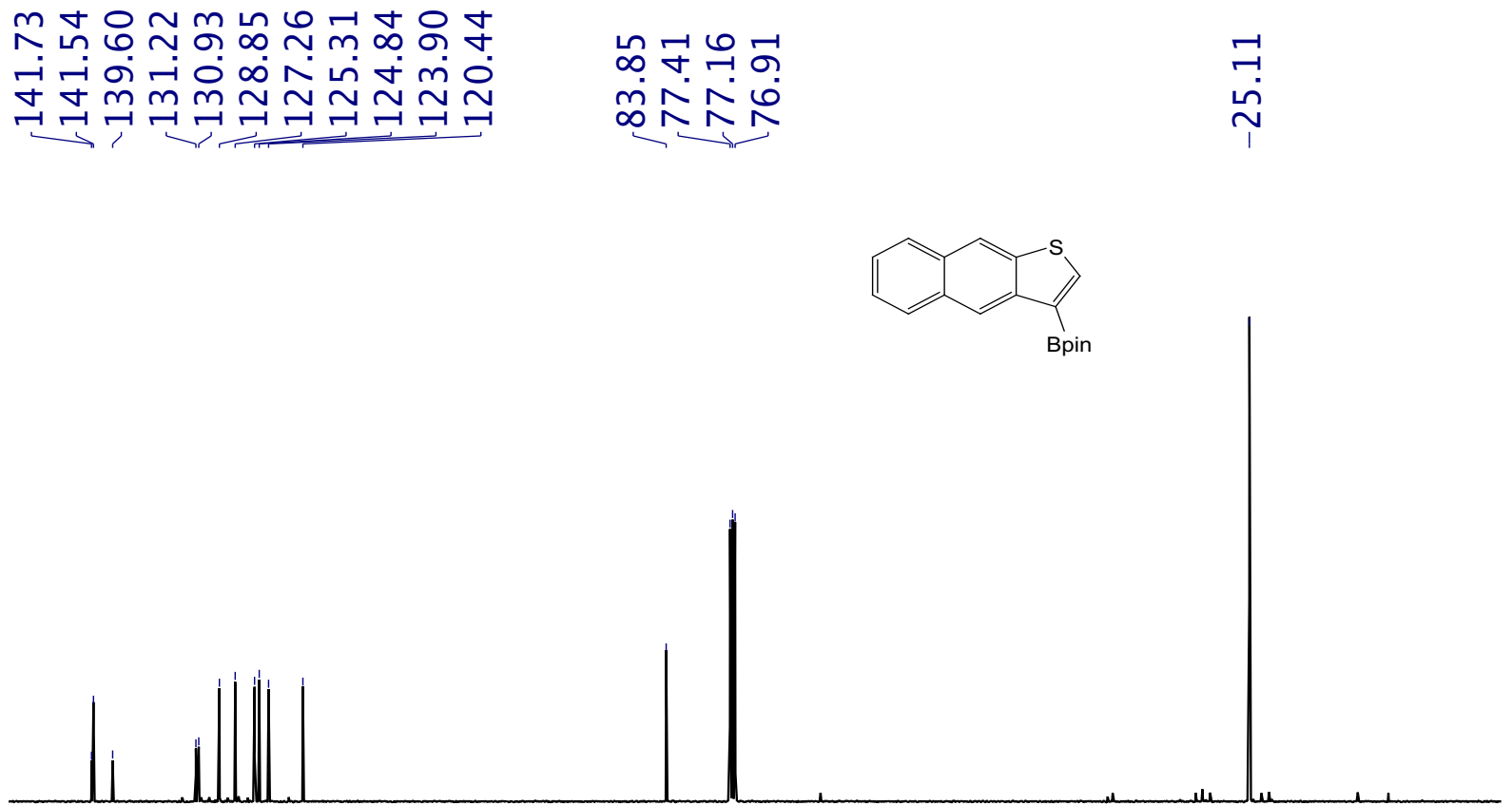

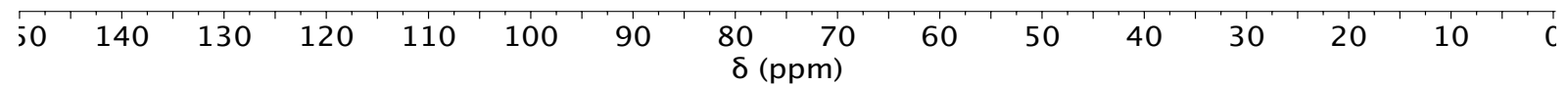

Figure S12. ${ }^{13} \mathrm{C}$ NMR spectrum $\left(\mathrm{CDCl}_{3}, 126 \mathrm{MHz}\right)$ of compound $\mathbf{1 1 a}$. 

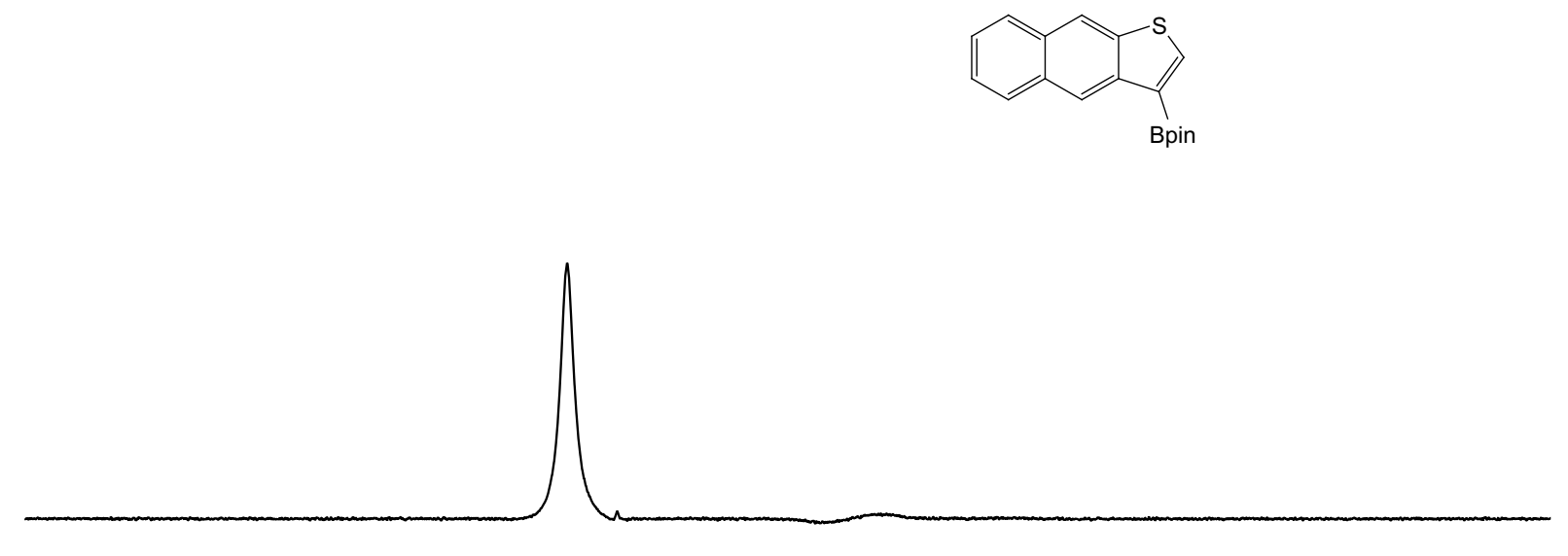

\begin{tabular}{|c|c|c|c|c|c|c|c|c|c|}
\hline 00 & 80 & 60 & 40 & 20 & $\delta\left(\begin{array}{c}0 \\
(p p m)\end{array}\right.$ & -20 & -40 & -60 & -80 \\
\hline
\end{tabular}

Figure S13. ${ }^{11} \mathrm{~B}$ NMR spectrum $\left(\mathrm{CDCl}_{3}, 160 \mathrm{MHz}\right)$ of compound $11 \mathrm{a}$.

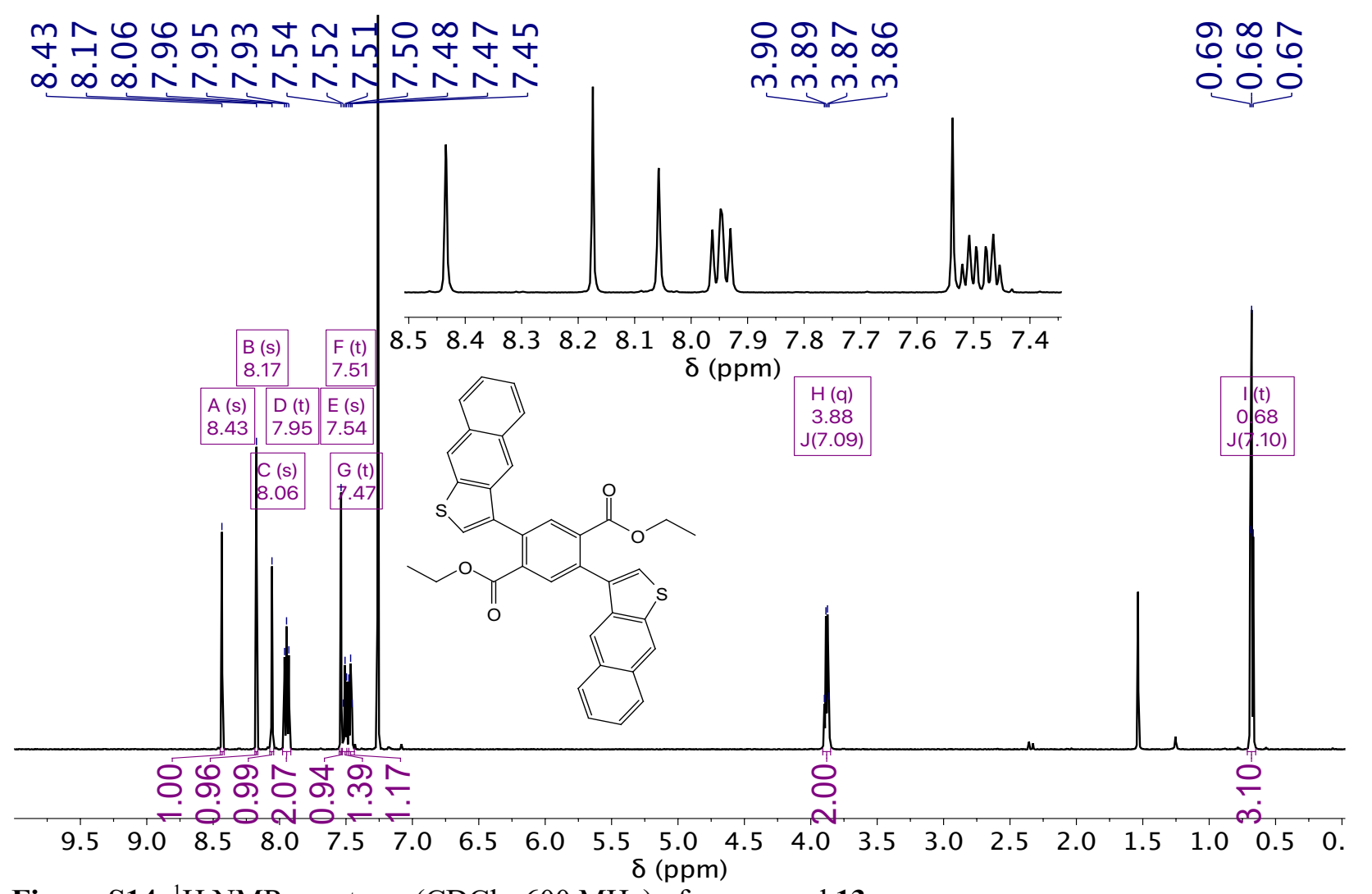

Figure S14. ${ }^{1} \mathrm{H}$ NMR spectrum $\left(\mathrm{CDCl}_{3}, 600 \mathrm{MHz}\right)$ of compound 13a. 


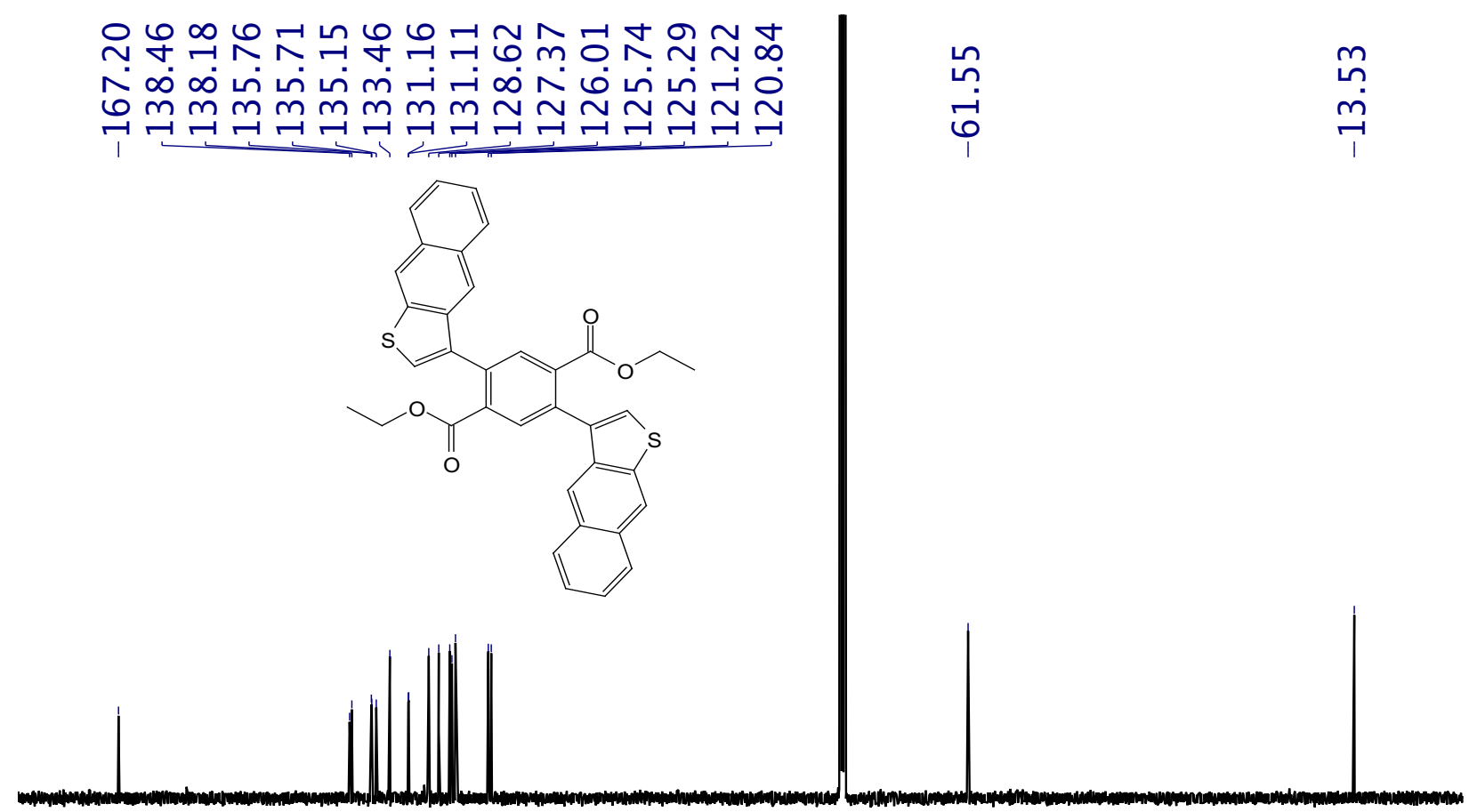

$\begin{array}{lllllllllllllll}170 & 160 & 150 & 140 & 130 & 120 & 110 & 100 \underset{\delta(\mathrm{ppm})}{90} 80 & 70 & 60 & 50 & 40 & 30 & 20 & 10\end{array}$

Figure S15. ${ }^{13} \mathrm{C}$ NMR spectrum $\left(\mathrm{CDCl}_{3}, 126 \mathrm{MHz}\right)$ of compound 13a.

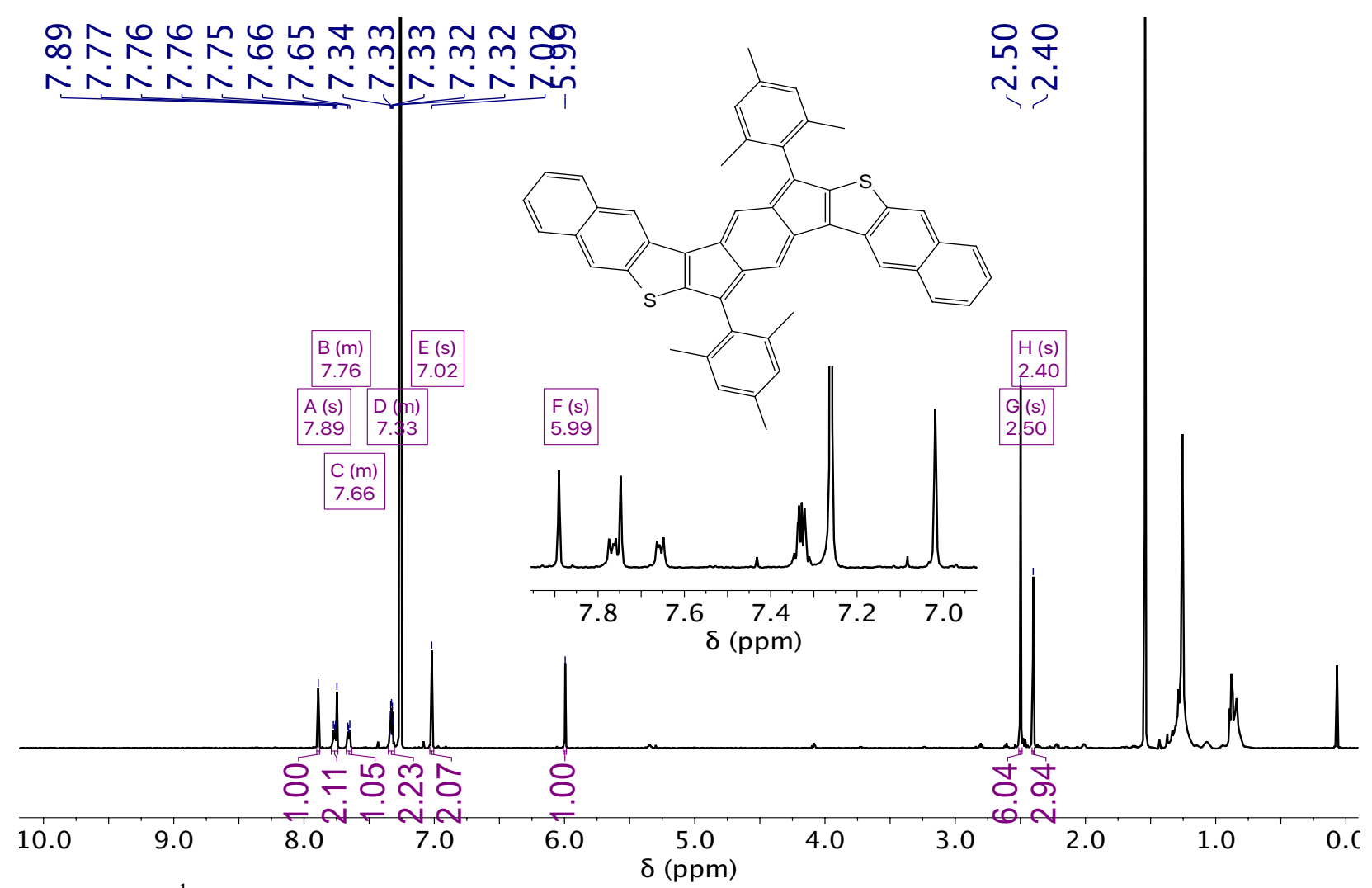

Figure S16. ${ }^{1} \mathrm{H}$ NMR spectrum $\left(\mathrm{CDCl}_{3}, 600 \mathrm{MHz}\right)$ of $s y n$-IDNT 4. 


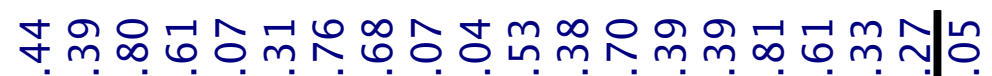

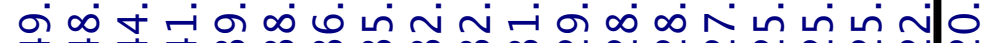

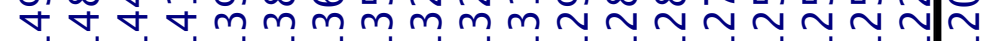

ชั นุ

iำ

$\sim$
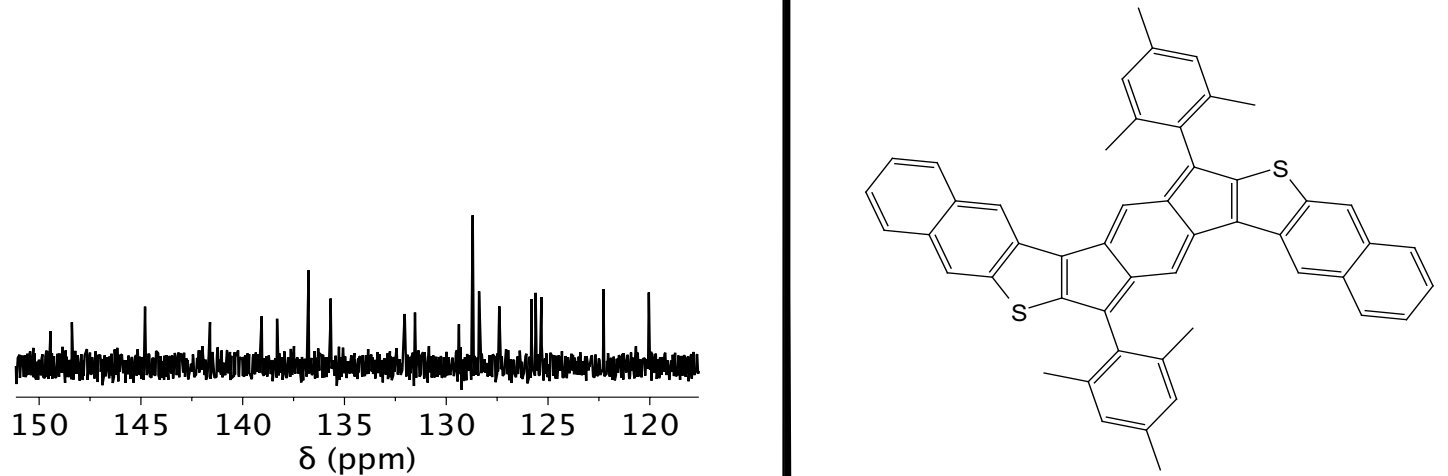

\begin{tabular}{lllllllllllllllllll}
\hline 30 & 170 & 160 & 150 & 140 & 130 & 120 & 110 & 100 & $\underset{\delta(\mathrm{ppm})}{90}$ & 80 & 70 & 60 & 50 & 40 & 30 & 20 & 10 & 0
\end{tabular}

Figure S17. ${ }^{13} \mathrm{C}$ NMR spectrum $\left(\mathrm{CDCl}_{3}, 151 \mathrm{MHz}\right)$ of syn-IDNT 4.

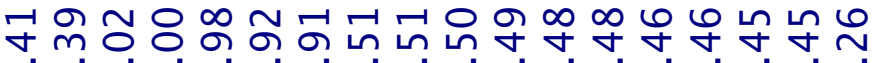

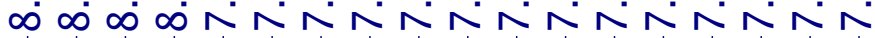

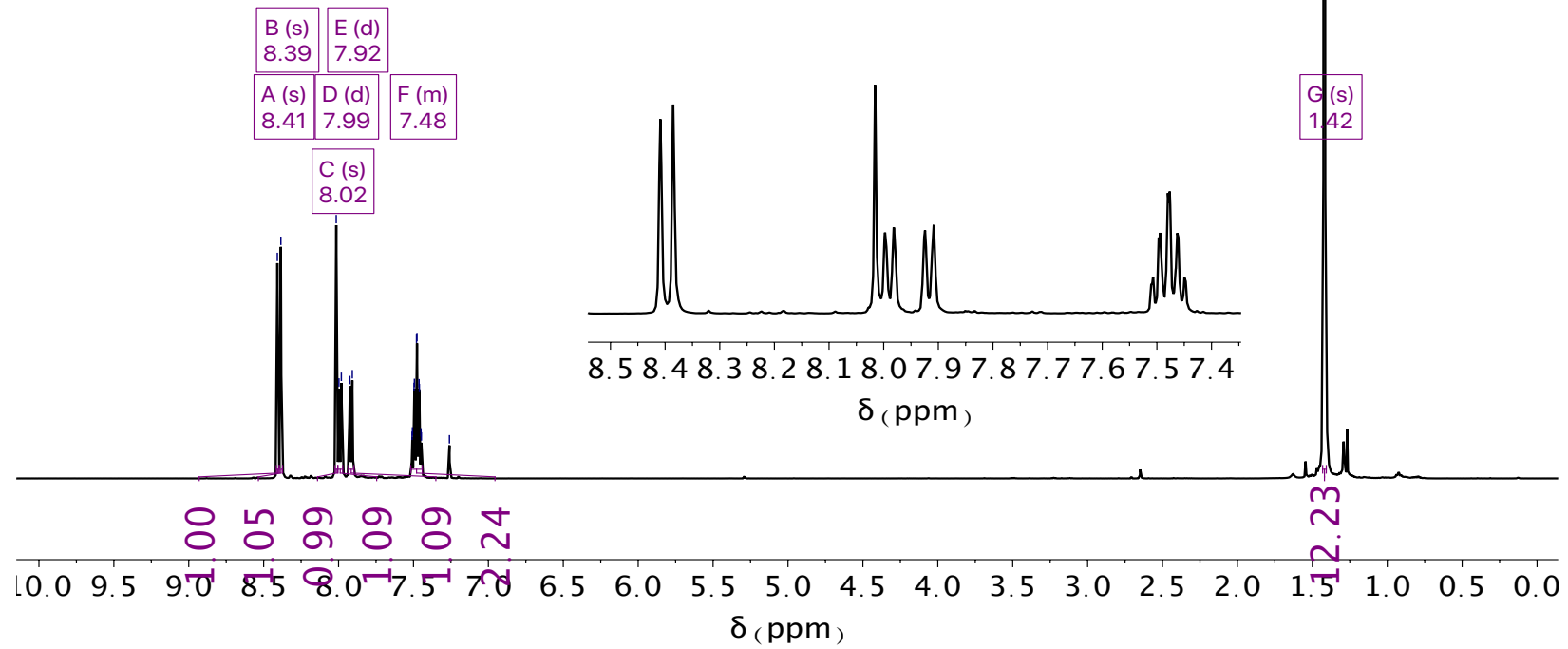

Figure S18. ${ }^{1} \mathrm{H}$ NMR spectrum $\left(\mathrm{CDCl}_{3}, 500 \mathrm{MHz}\right)$ of compound $\mathbf{1 1 b}$. 


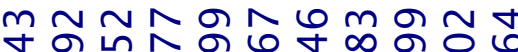

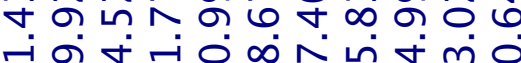
$\forall m m m m \sim \sim \sim \sim$ म $m$ m त

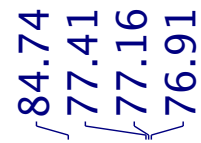

๙ั

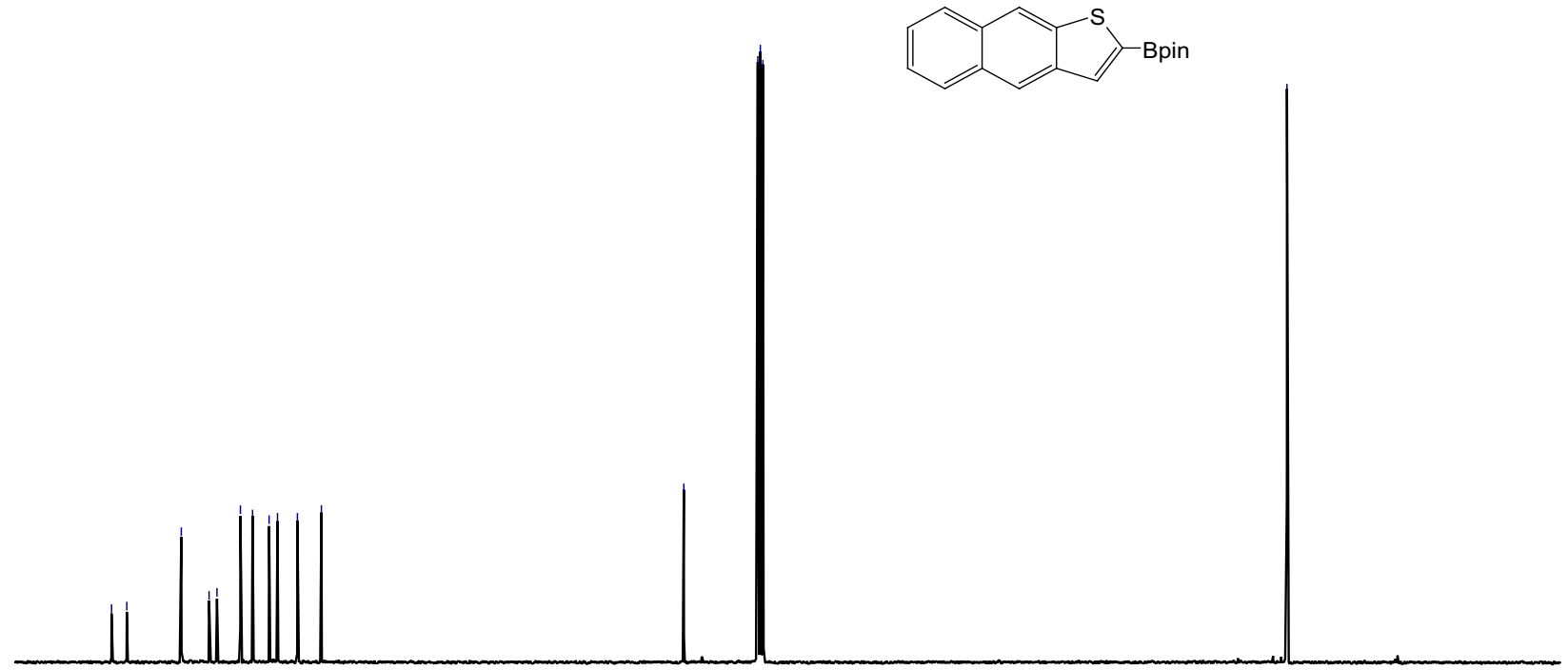

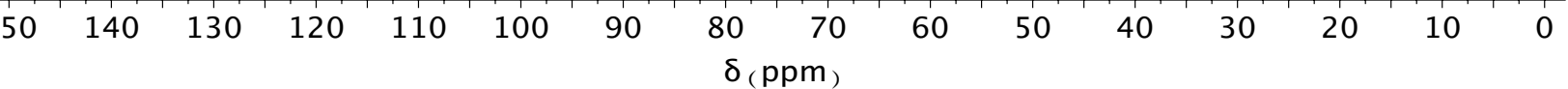

Figure S19. ${ }^{13} \mathrm{C}$ NMR spectrum $\left(\mathrm{CDCl}_{3}, 126 \mathrm{MHz}\right)$ of compound $\mathbf{1 1 b}$.

กั่
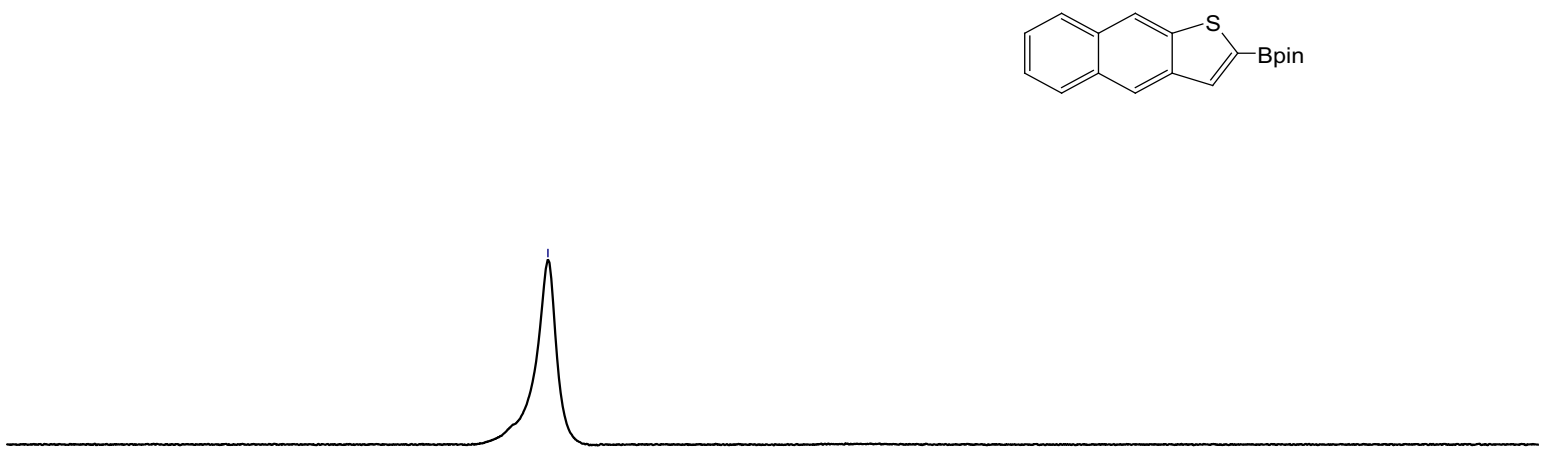

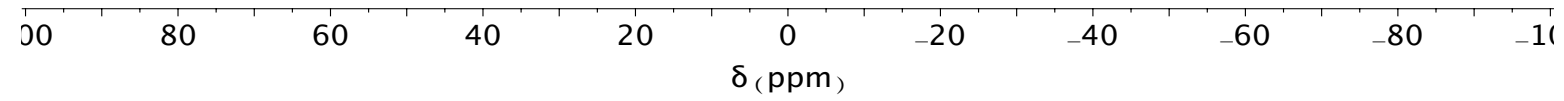

Figure S20. ${ }^{11} \mathrm{~B}$ NMR spectrum $\left(\mathrm{CDCl}_{3}, 160 \mathrm{MHz}\right)$ of compound $\mathbf{1 1 b}$. 


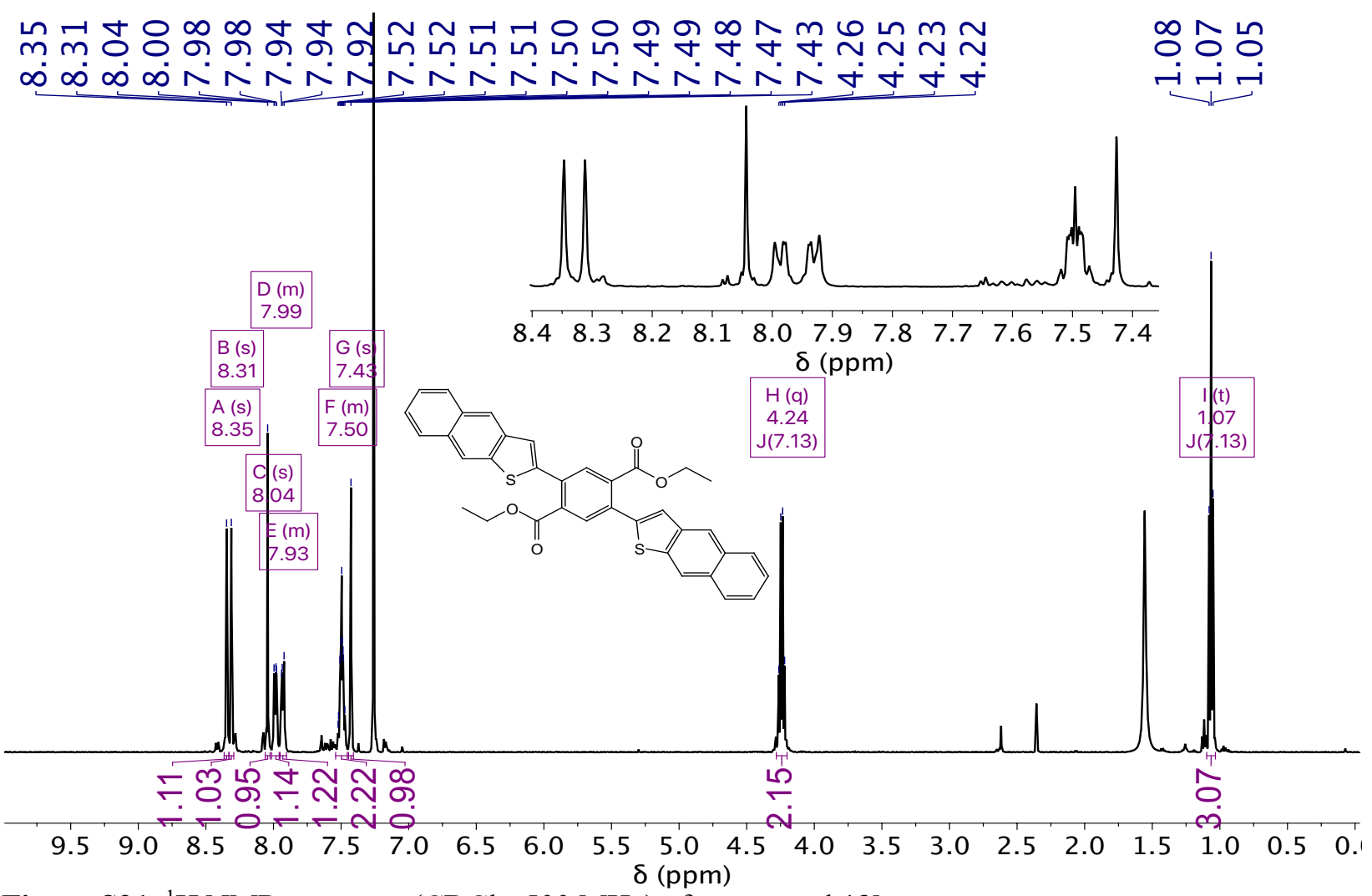

Figure S21. ${ }^{1} \mathrm{H}$ NMR spectrum $\left(\mathrm{CDCl}_{3}, 500 \mathrm{MHz}\right)$ of compound $\mathbf{1 3 b}$.
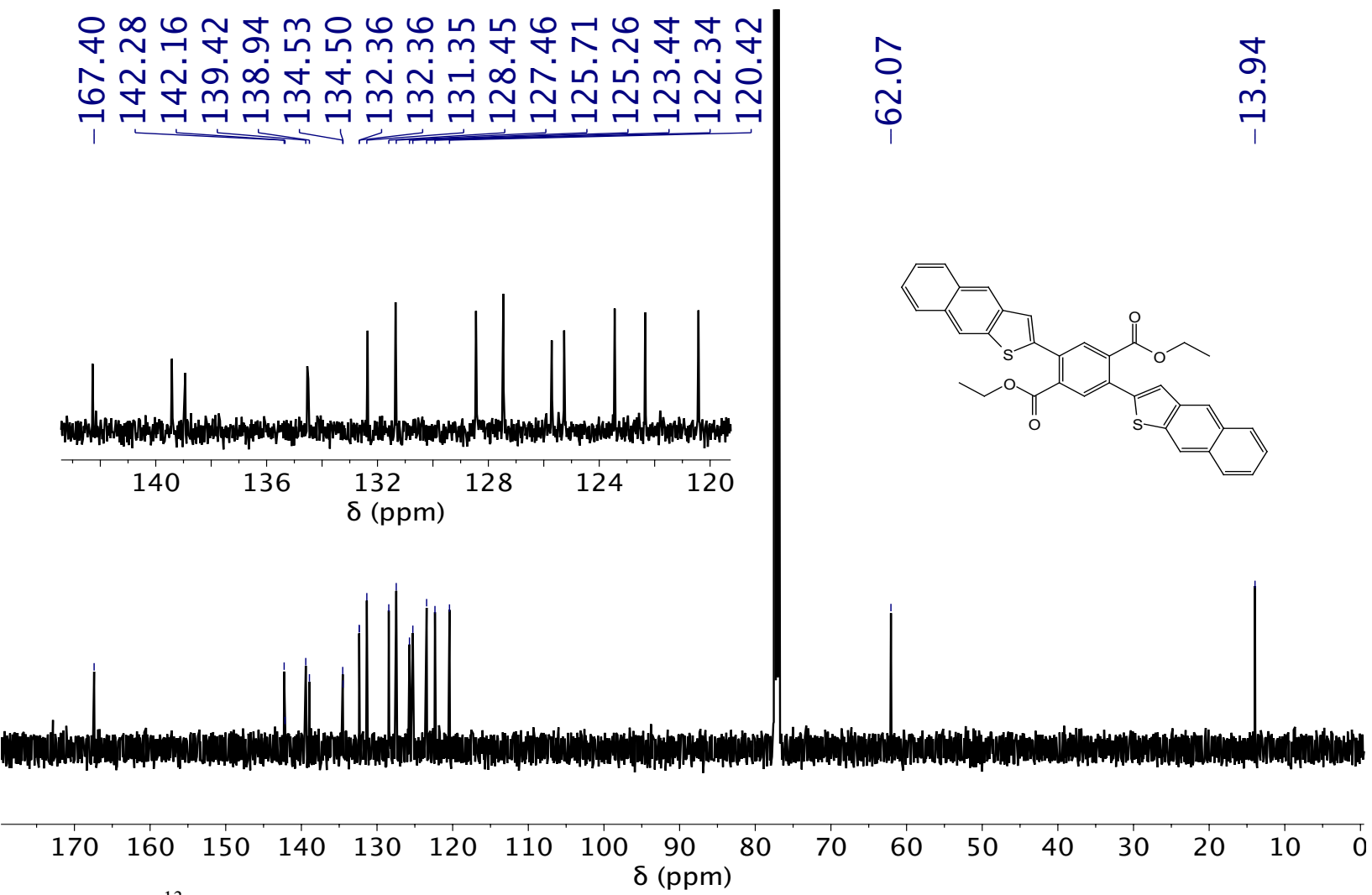

Figure S22. ${ }^{13} \mathrm{C}$ NMR spectrum $\left(\mathrm{CDCl}_{3}, 126 \mathrm{MHz}\right)$ of compound $\mathbf{1 3 b}$. 


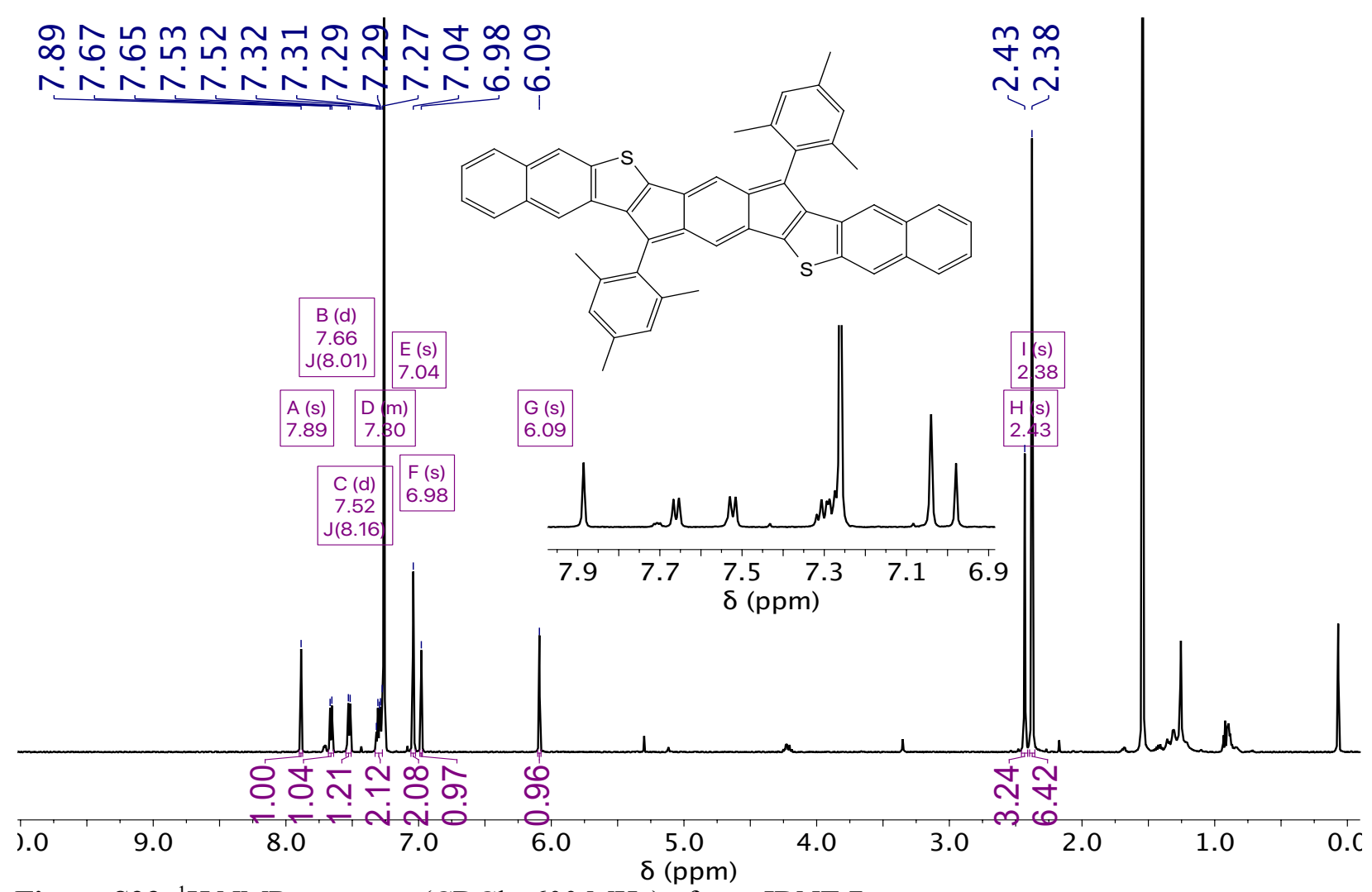

Figure S23. ${ }^{1} \mathrm{H}$ NMR spectrum $\left(\mathrm{CDCl}_{3}, 600 \mathrm{MHz}\right)$ of anti-IDNT 7.

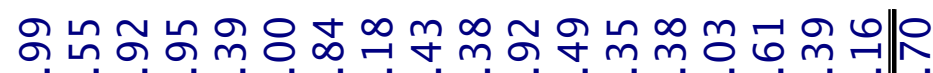

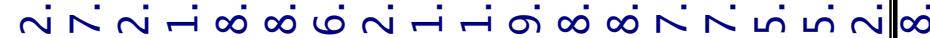

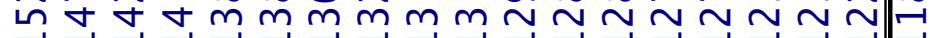
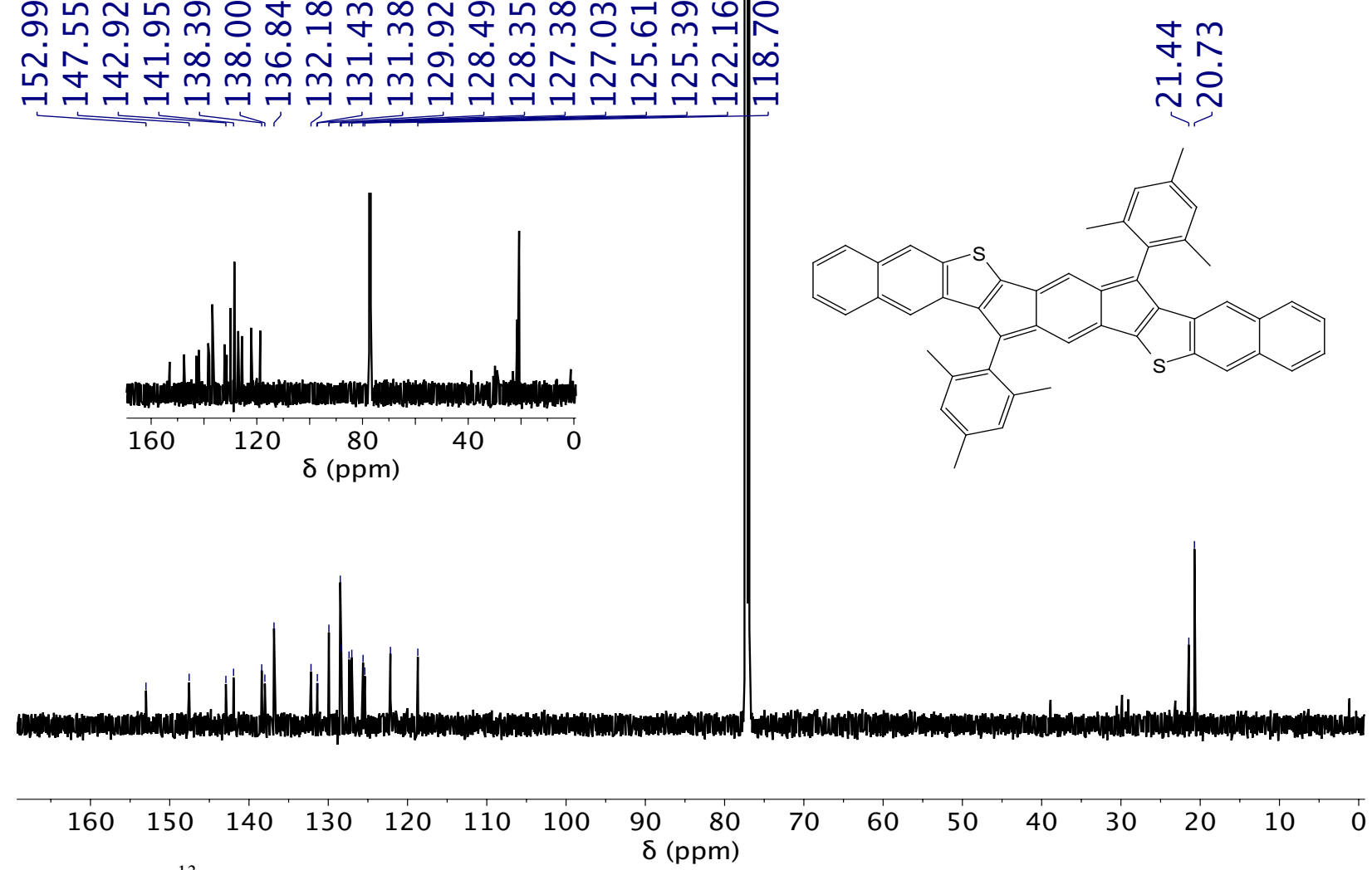

Figure S24. ${ }^{13} \mathrm{C}$ NMR spectrum $\left(\mathrm{CDCl}_{3}, 126 \mathrm{MHz}\right)$ of anti-IDNT 7. 
$\infty 6 \sim \sqcap$ เ

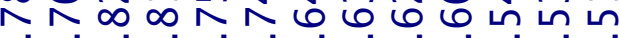

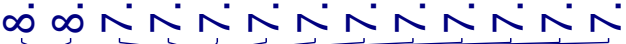

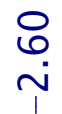
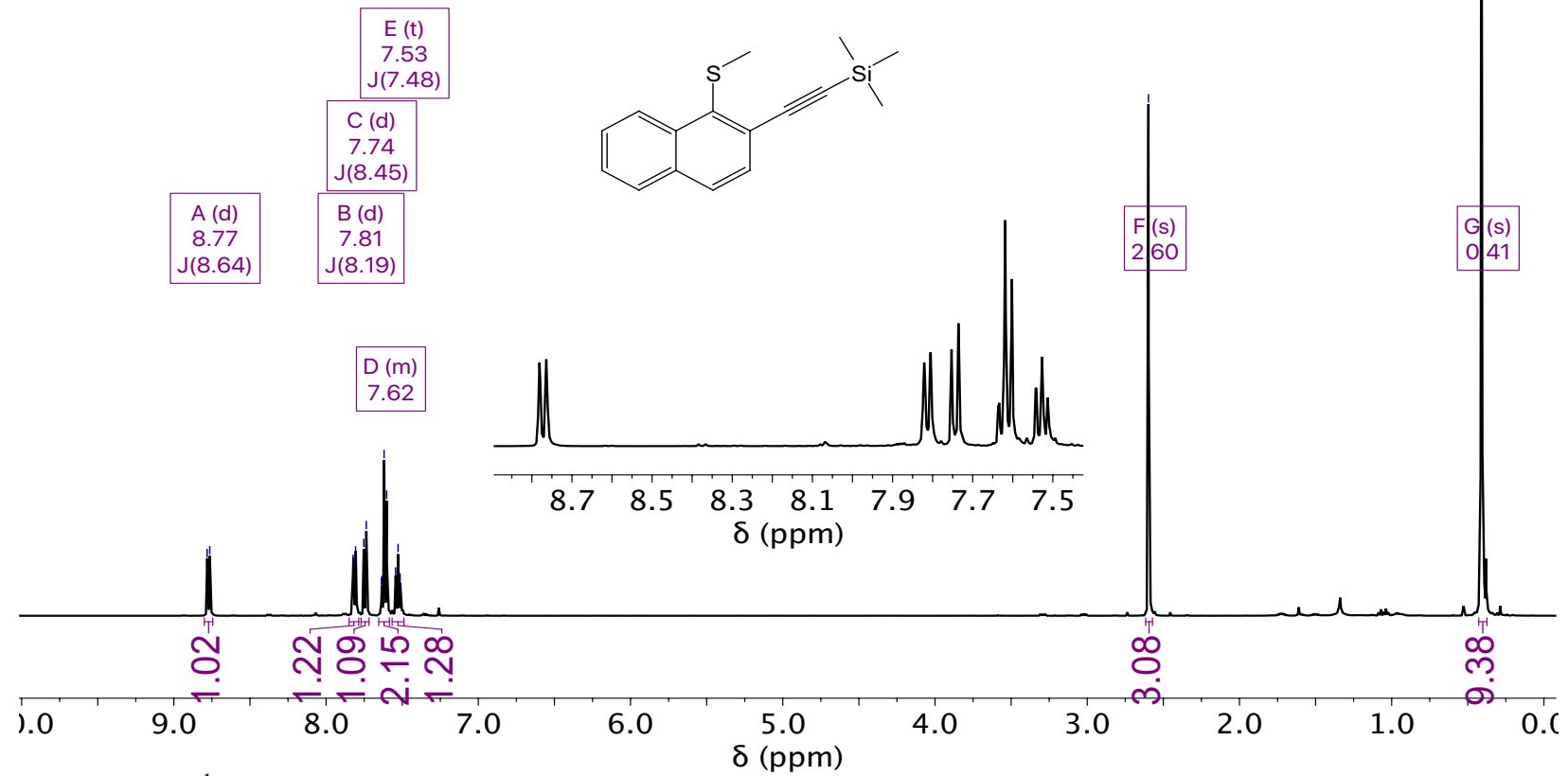

Figure S25. ${ }^{1} \mathrm{H}$ NMR spectrum $\left(\mathrm{CDCl}_{3}, 500 \mathrm{MHz}\right)$ of compound $\mathbf{S} 7$.
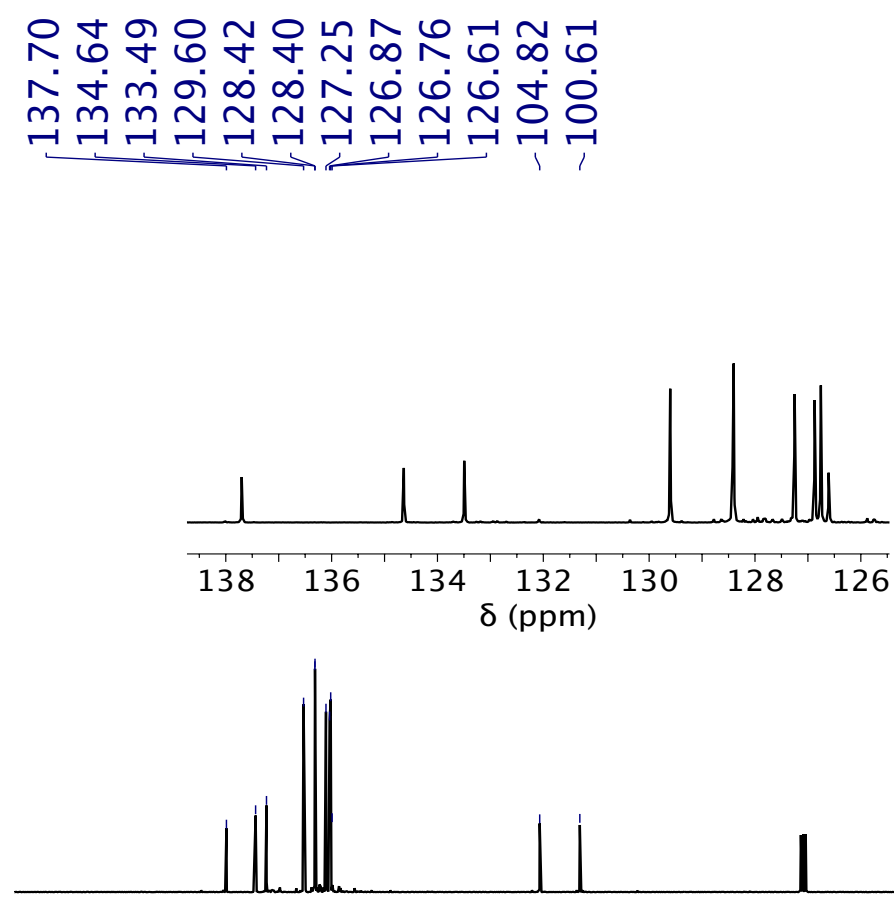
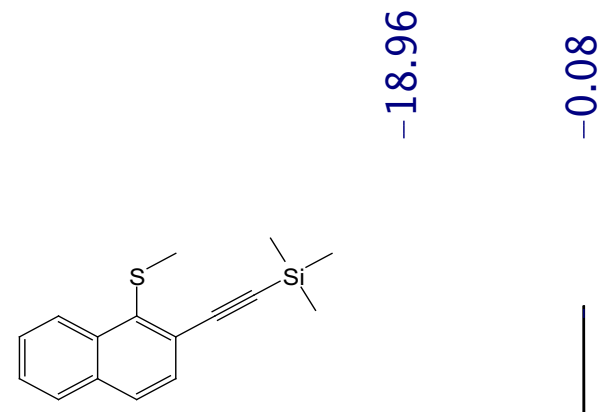

$\begin{array}{llllll}150 & 140 & 130 & 120 & 110 & 100\end{array}$

$80 \quad 70$
$\delta(\mathrm{ppm})$

Figure S26. ${ }^{13} \mathrm{C}$ NMR spectrum $\left(\mathrm{CDCl}_{3}, 126 \mathrm{MHz}\right)$ of compound $\mathbf{S 7}$. 

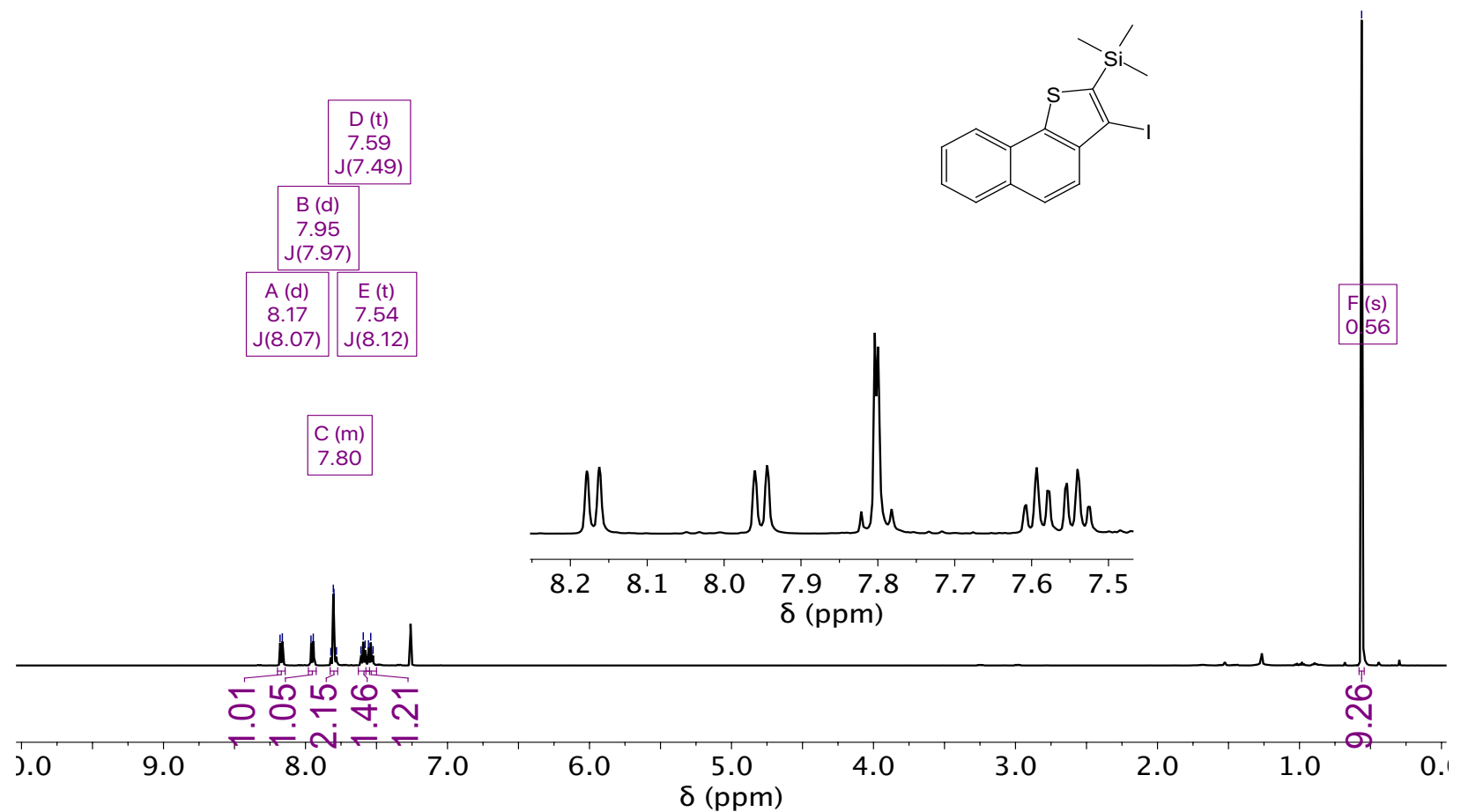

Figure S27. ${ }^{1} \mathrm{H}$ NMR spectrum $\left(\mathrm{CDCl}_{3}, 500 \mathrm{MHz}\right)$ of compound $\mathbf{S 8}$.
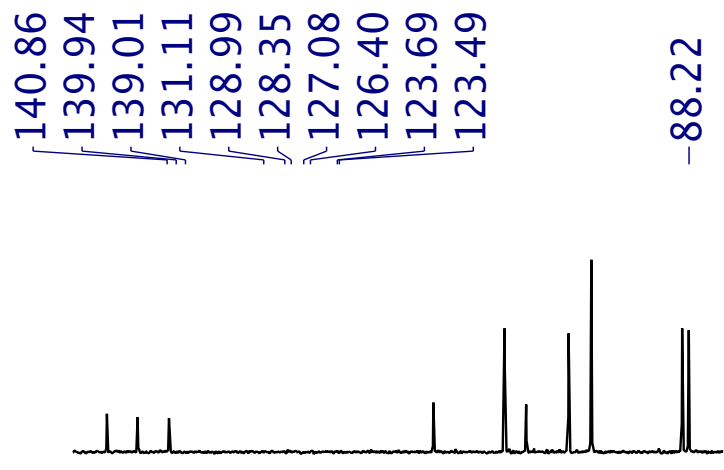

140138136134132130128126124 $\delta(\mathrm{ppm})$
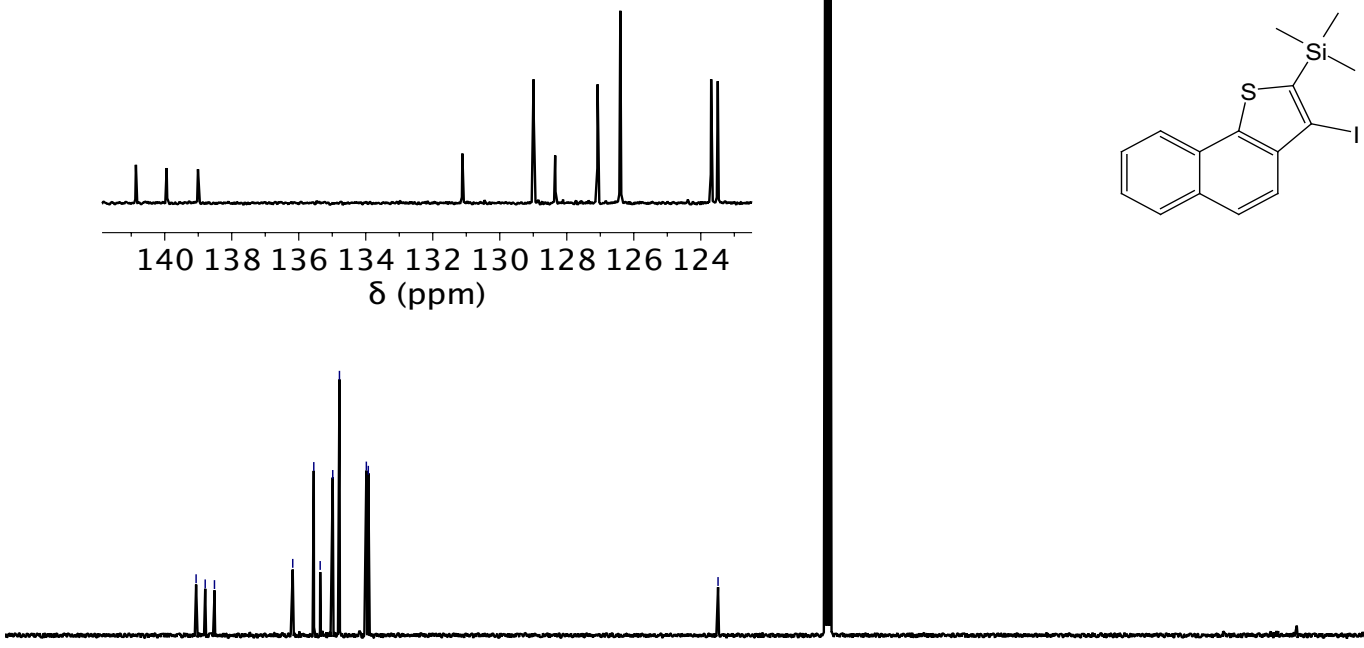

$\begin{array}{llllllllll}50 & 150 & 140 & 130 & 120 & 110 & 100 & 90 & \begin{array}{c}80 \\ \delta(\mathrm{ppm})\end{array} & 70\end{array}$

Figure S28. ${ }^{13} \mathrm{C}$ NMR spectrum $\left(\mathrm{CDCl}_{3}, 126 \mathrm{MHz}\right)$ of compound $\mathbf{S 8}$. 


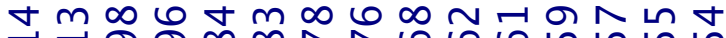
구

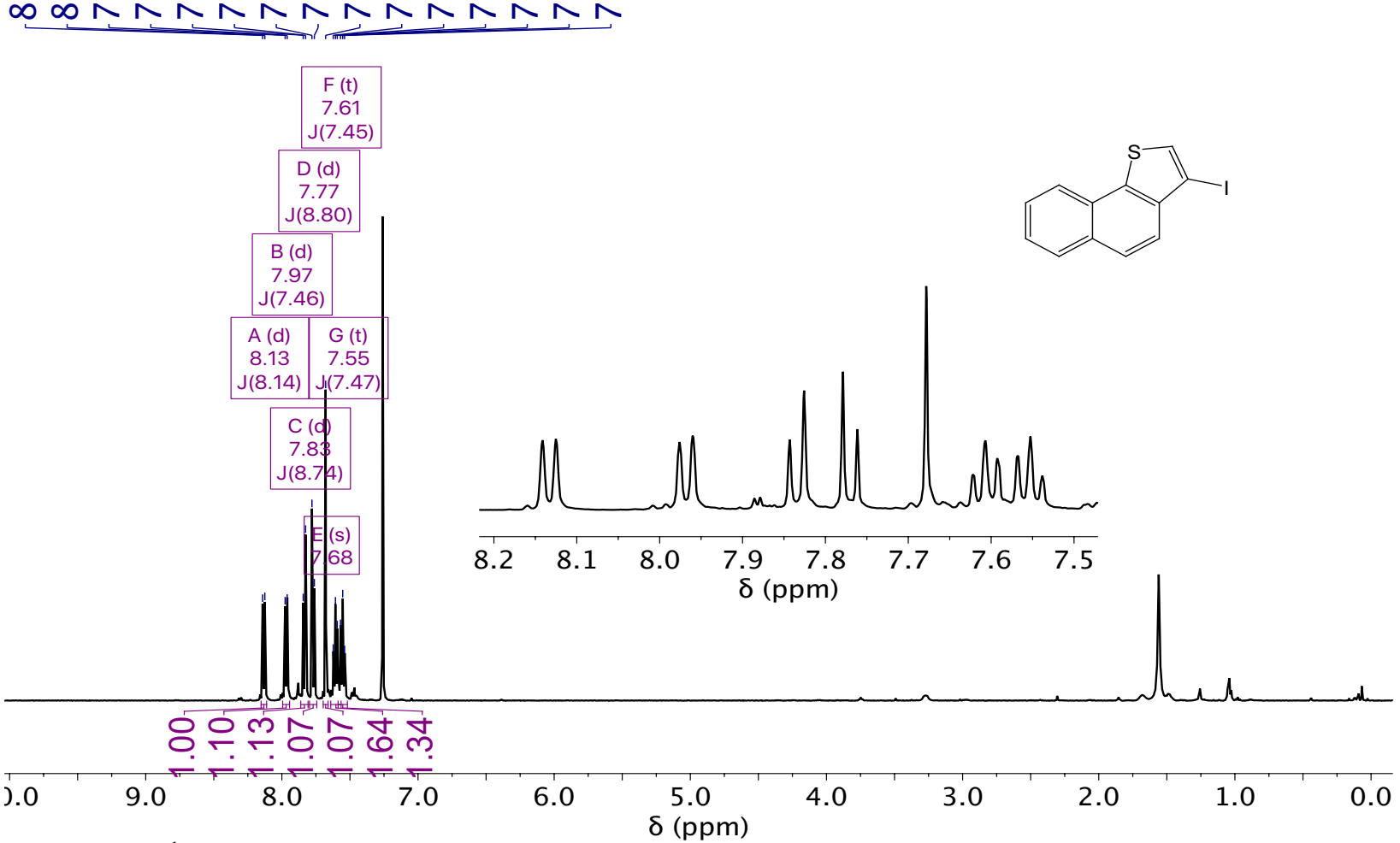

Figure S29. ${ }^{1} \mathrm{H}$ NMR spectrum $\left(\mathrm{CDCl}_{3}, 500 \mathrm{MHz}\right)$ of compound $\mathbf{1 0 a}$.

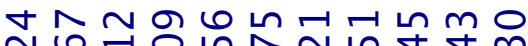

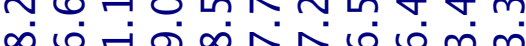
$m m m \sim \sim \sim \sim \sim \sim \sim$ मान म
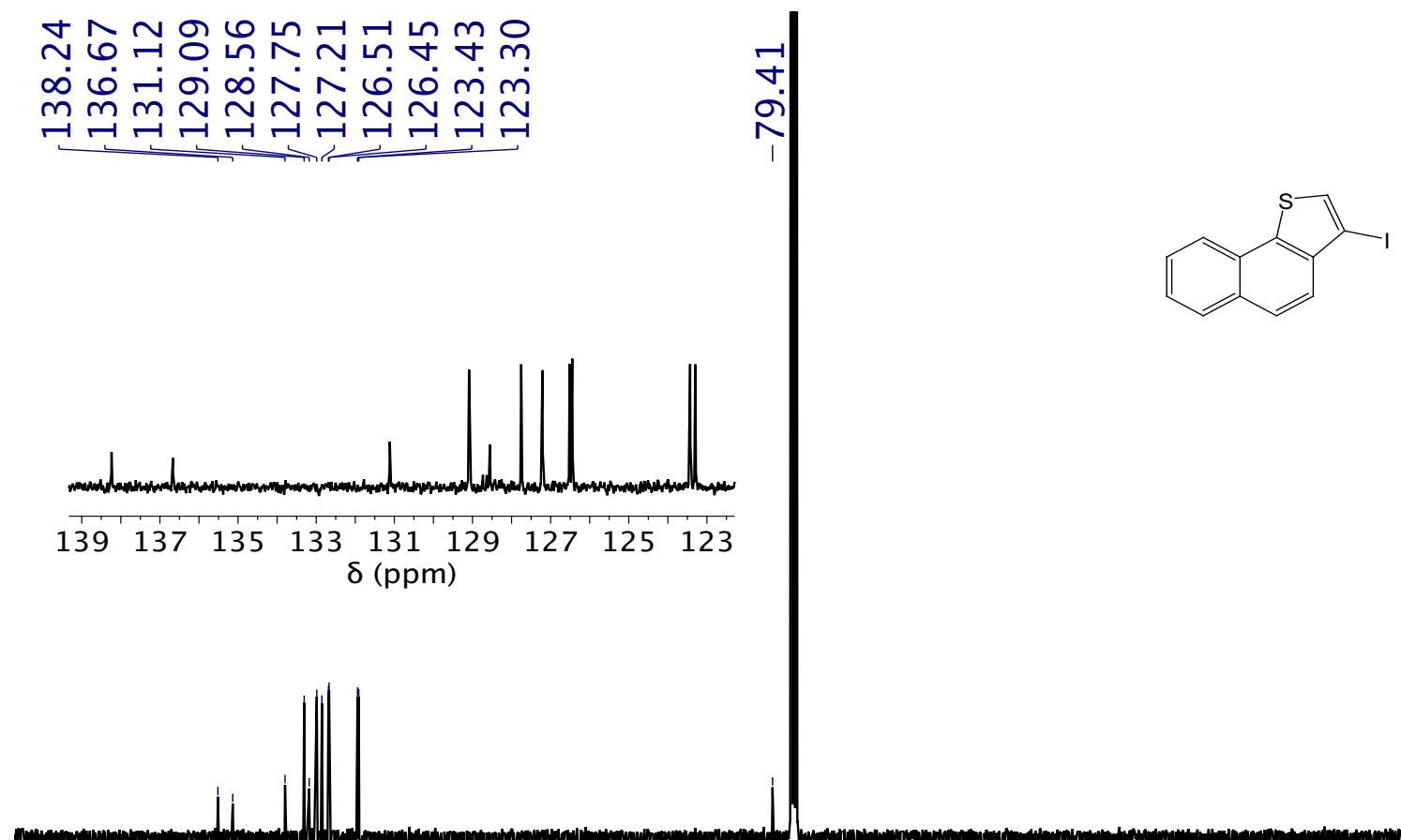

$\begin{array}{llllllllllllllll}150 & 140 & 130 & 120 & 110 & 100 & 90 & \begin{array}{c}80 \\ \delta(\mathrm{ppm})\end{array} & 70 & 60 & 50 & 40 & 30 & 20 & 10 & 0\end{array}$

Figure S30. ${ }^{13} \mathrm{C}$ NMR spectrum $\left(\mathrm{CDCl}_{3}, 126 \mathrm{MHz}\right)$ of compound $\mathbf{1 0 a}$. 


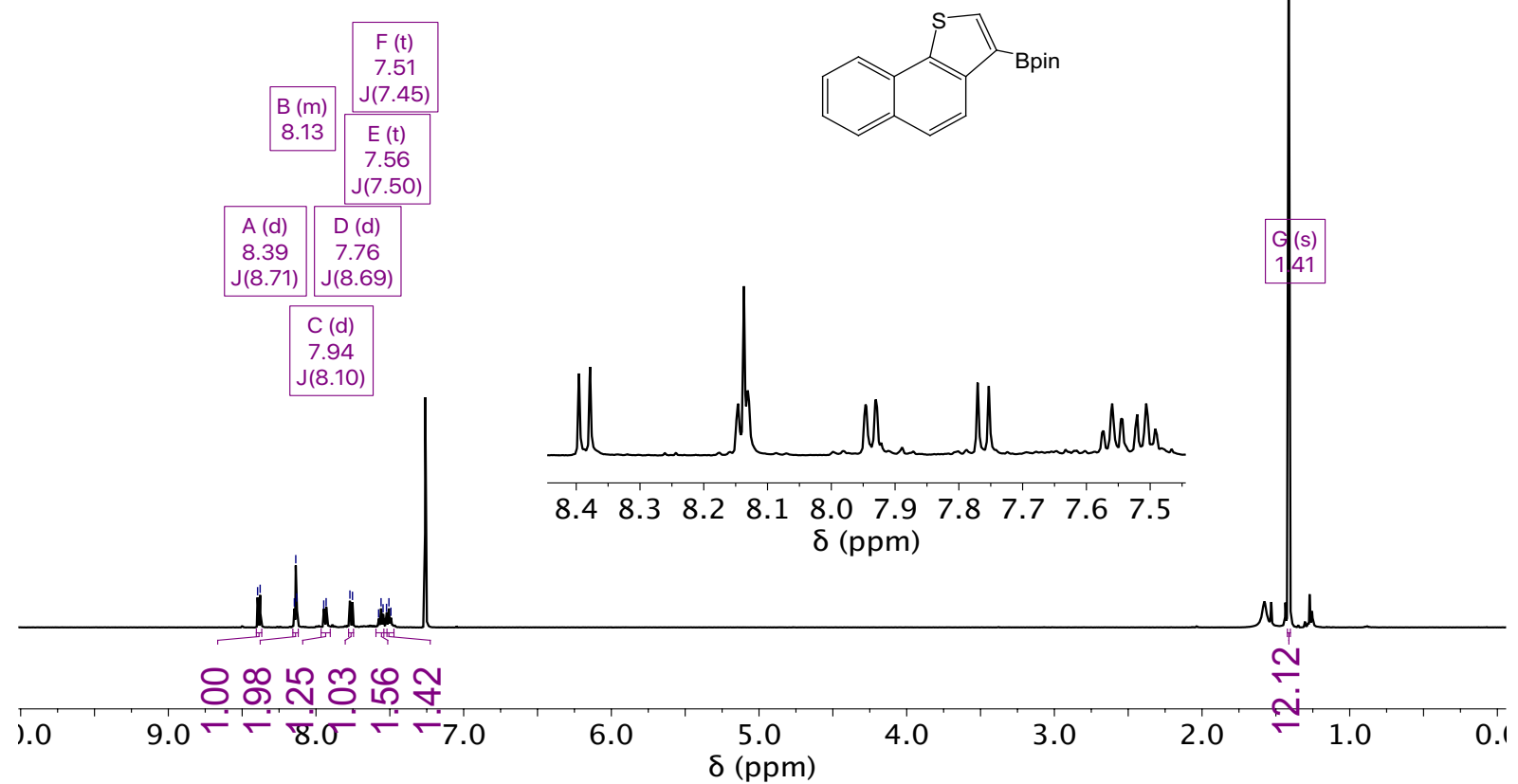

Figure S31. ${ }^{1} \mathrm{H}$ NMR spectrum $\left(\mathrm{CDCl}_{3}, 500 \mathrm{MHz}\right)$ of compound 12a.
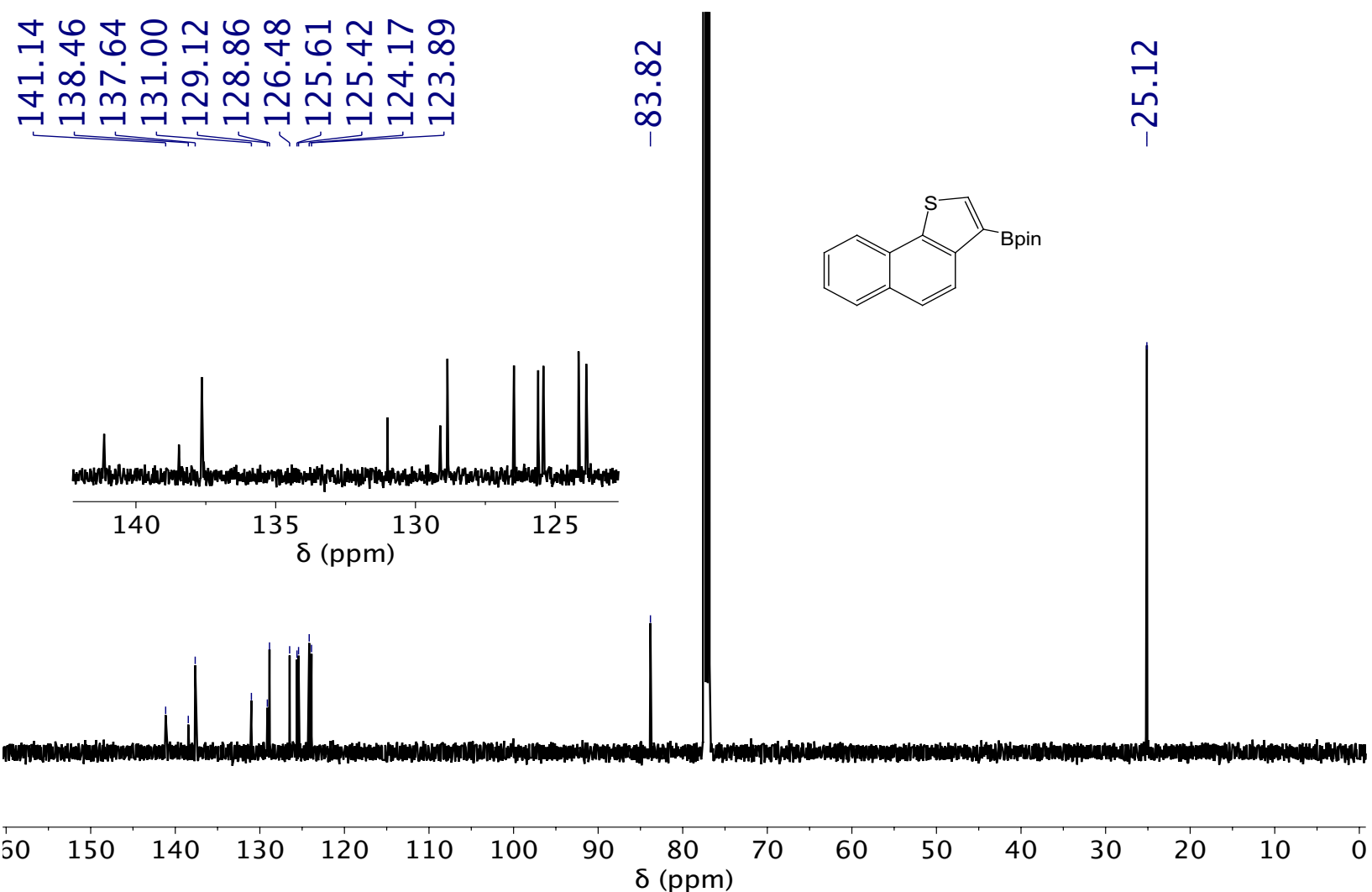

Figure S32. ${ }^{13} \mathrm{C}$ NMR spectrum $\left(\mathrm{CDCl}_{3}, 126 \mathrm{MHz}\right)$ of compound 12a. 
$\stackrel{0}{\sim}$
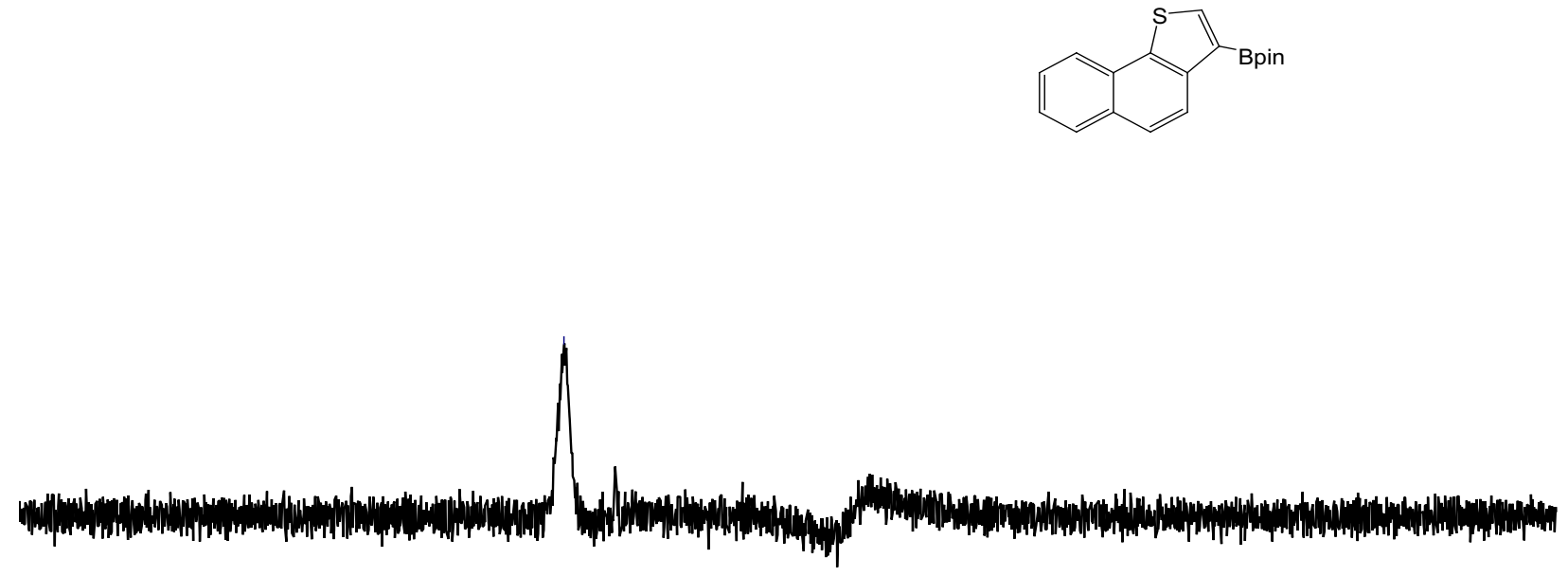

\begin{tabular}{|c|c|c|c|c|c|c|c|c|c|}
\hline כ0 & 80 & 60 & 40 & 20 & $\begin{array}{c}0 \\
\delta(\mathrm{ppm})\end{array}$ & -20 & -40 & -60 & -80 \\
\hline
\end{tabular}

Figure S33. ${ }^{11} \mathrm{~B}$ NMR spectrum $\left(\mathrm{CDCl}_{3}, 160 \mathrm{MHz}\right)$ of compound 12a.

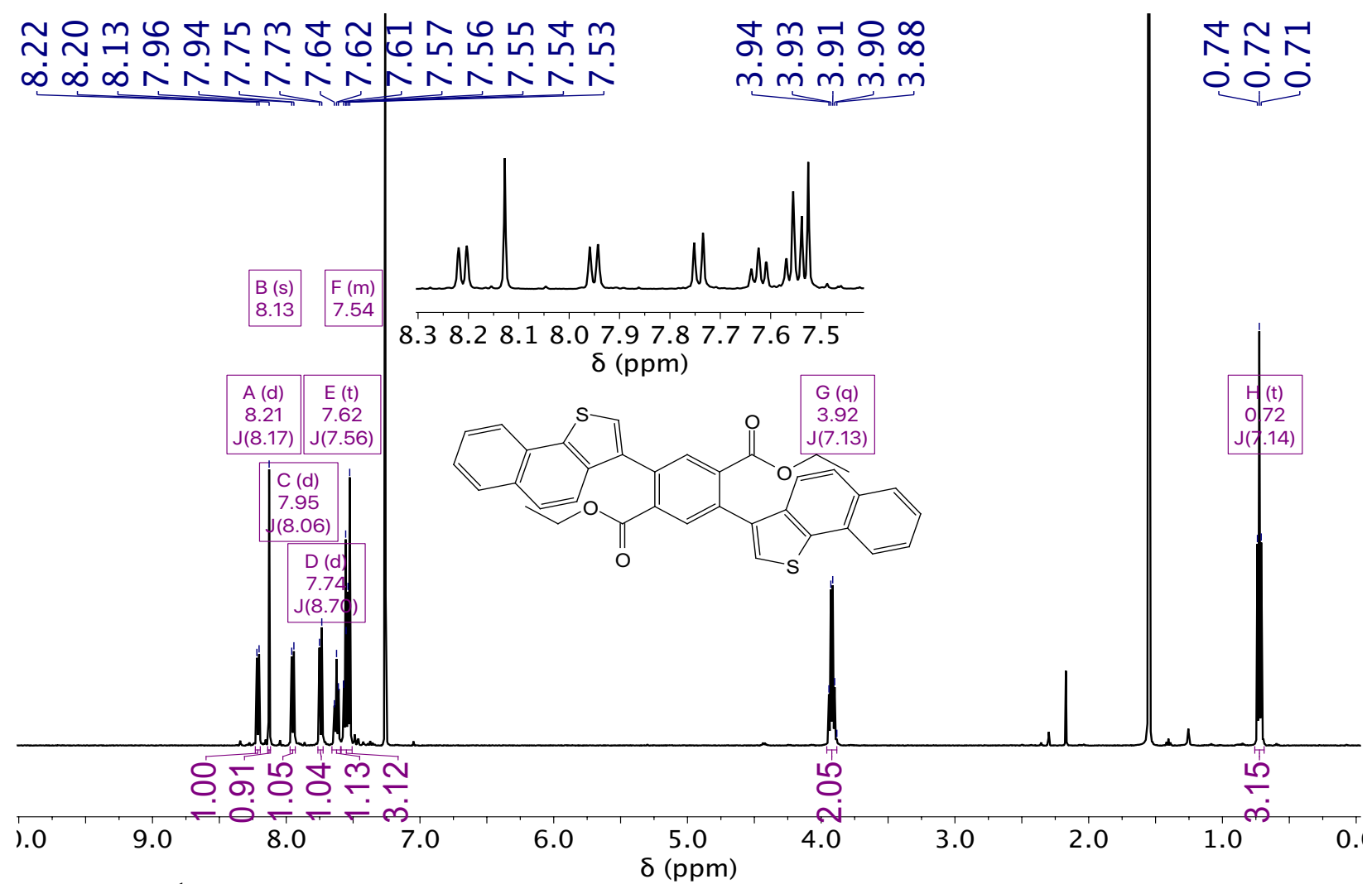

Figure S34. ${ }^{1} \mathrm{H}$ NMR spectrum $\left(\mathrm{CDCl}_{3}, 500 \mathrm{MHz}\right)$ of compound $14 a$. 


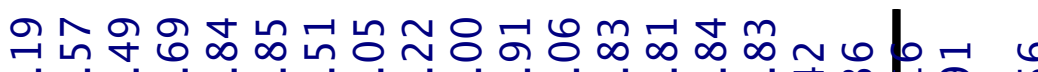

ヘं ヘं

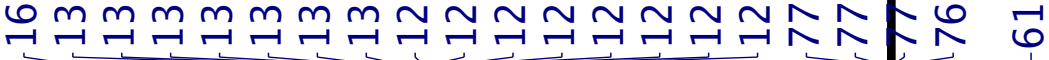

กั๋
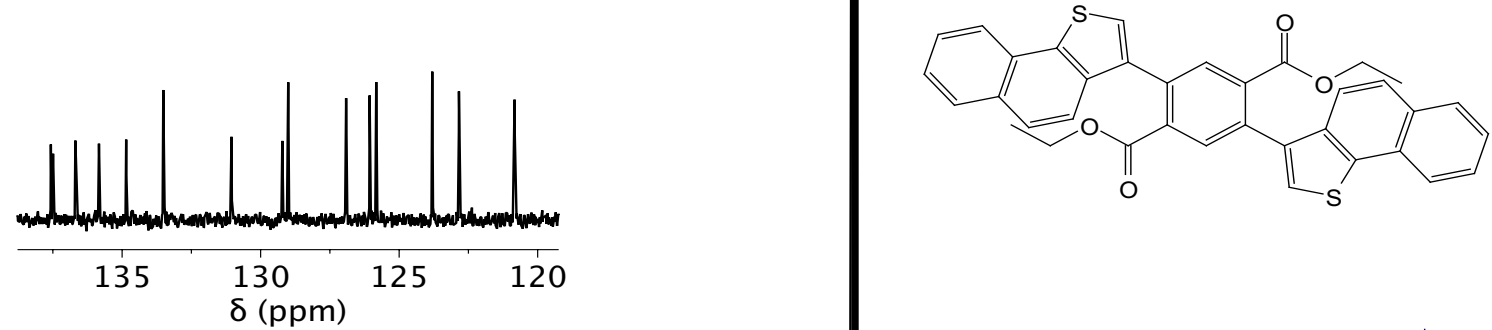

$\begin{array}{lllllllllll}30 & 170 & 160 & 150 & 140 & 130 & 120 & 110 & 100 & 90 \\ \delta(\mathrm{ppm}) & 80\end{array}$

Figure S35. ${ }^{13} \mathrm{C}$ NMR spectrum $\left(\mathrm{CDCl}_{3}, 126 \mathrm{MHz}\right)$ of compound $\mathbf{1 4 a}$.

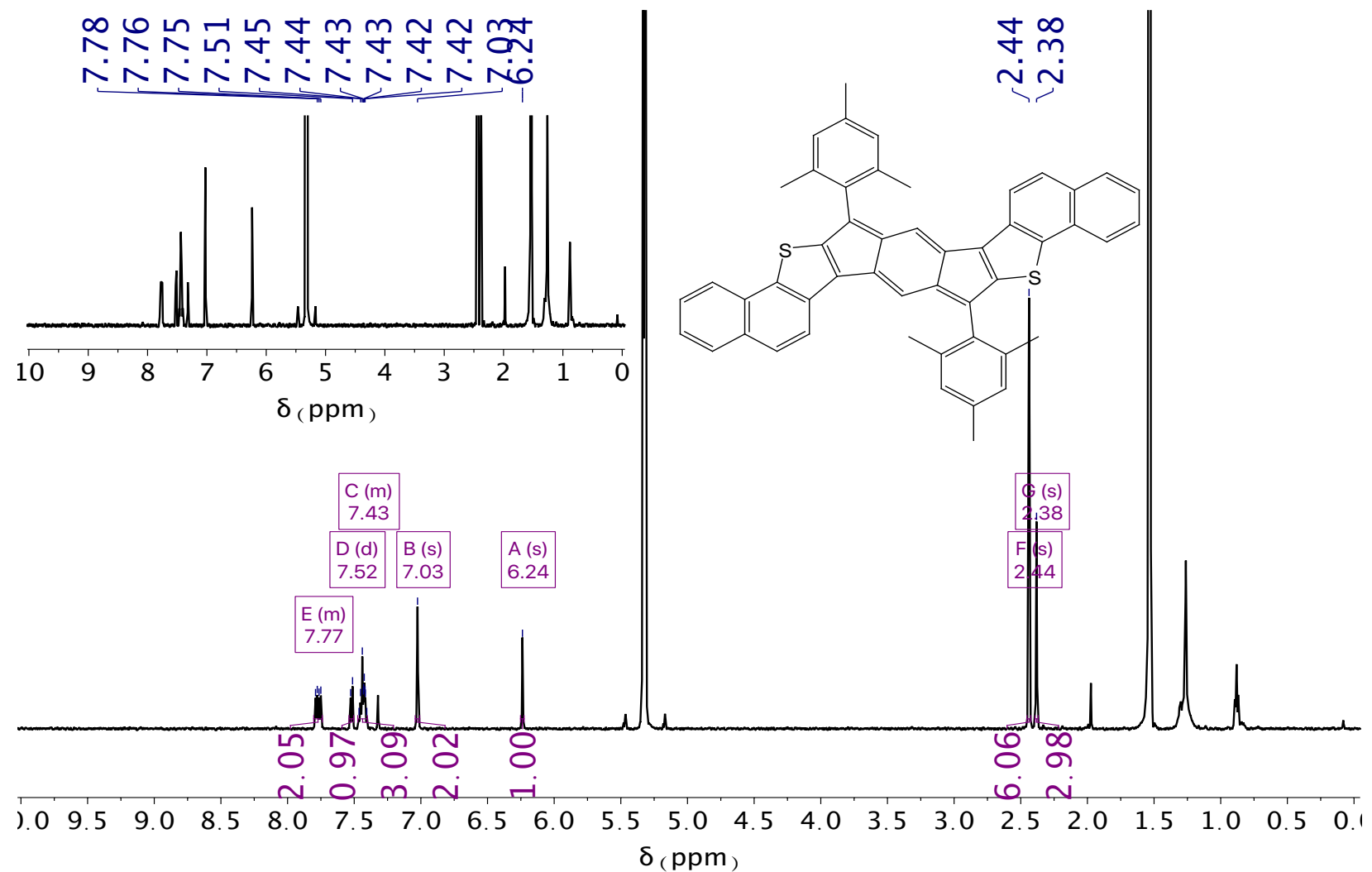

Figure S36. ${ }^{1} \mathrm{H}$ NMR spectrum $\left(\mathrm{CD}_{2} \mathrm{Cl}_{2}, 600 \mathrm{MHz}\right)$ of syn-IDNT 5. 


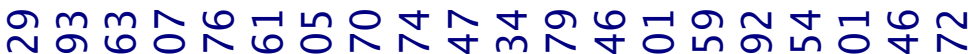

م $\forall \forall \forall \mathrm{mmmmmm \sim N \sim \sim \sim \sim N \sim}$ 개
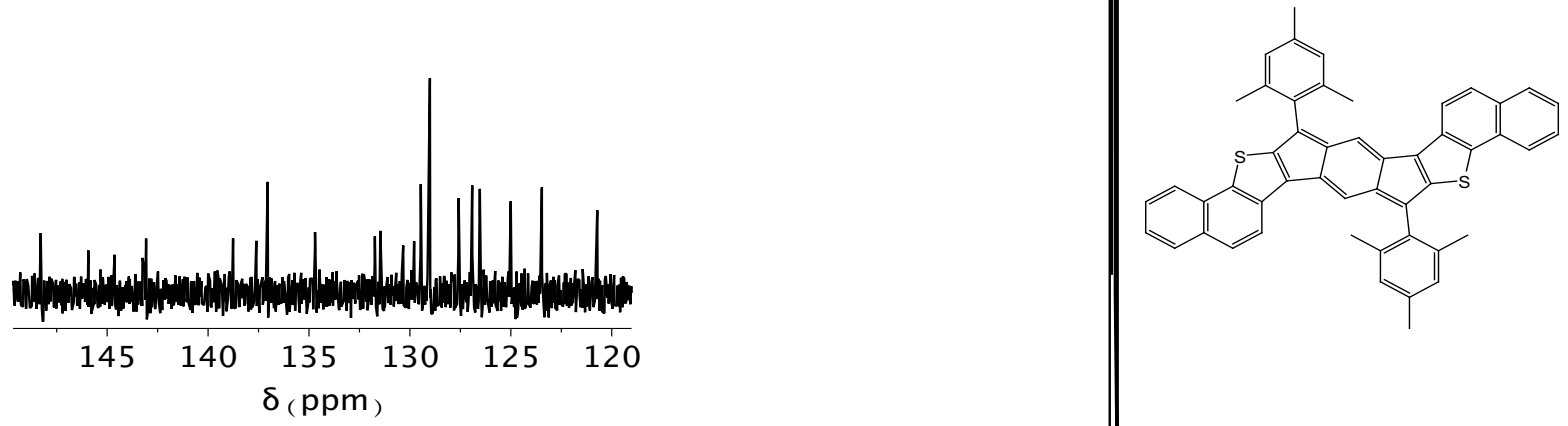

$\begin{array}{llllllll}170 & 160 & 150 & 140 & 130 & 120 & 110 & 100\end{array}$

Figure S37. ${ }^{13} \mathrm{C}$ NMR spectrum $\left(\mathrm{CD}_{2} \mathrm{Cl}_{2}, 151 \mathrm{MHz}\right)$ of syn-IDNT 5.

$m \sqcap m+N$ L $m m-7 \rightarrow 009 \infty \infty 66$ L

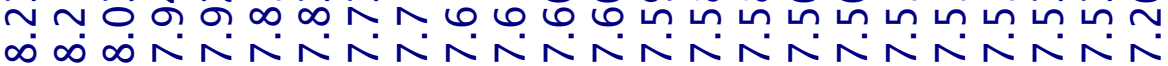

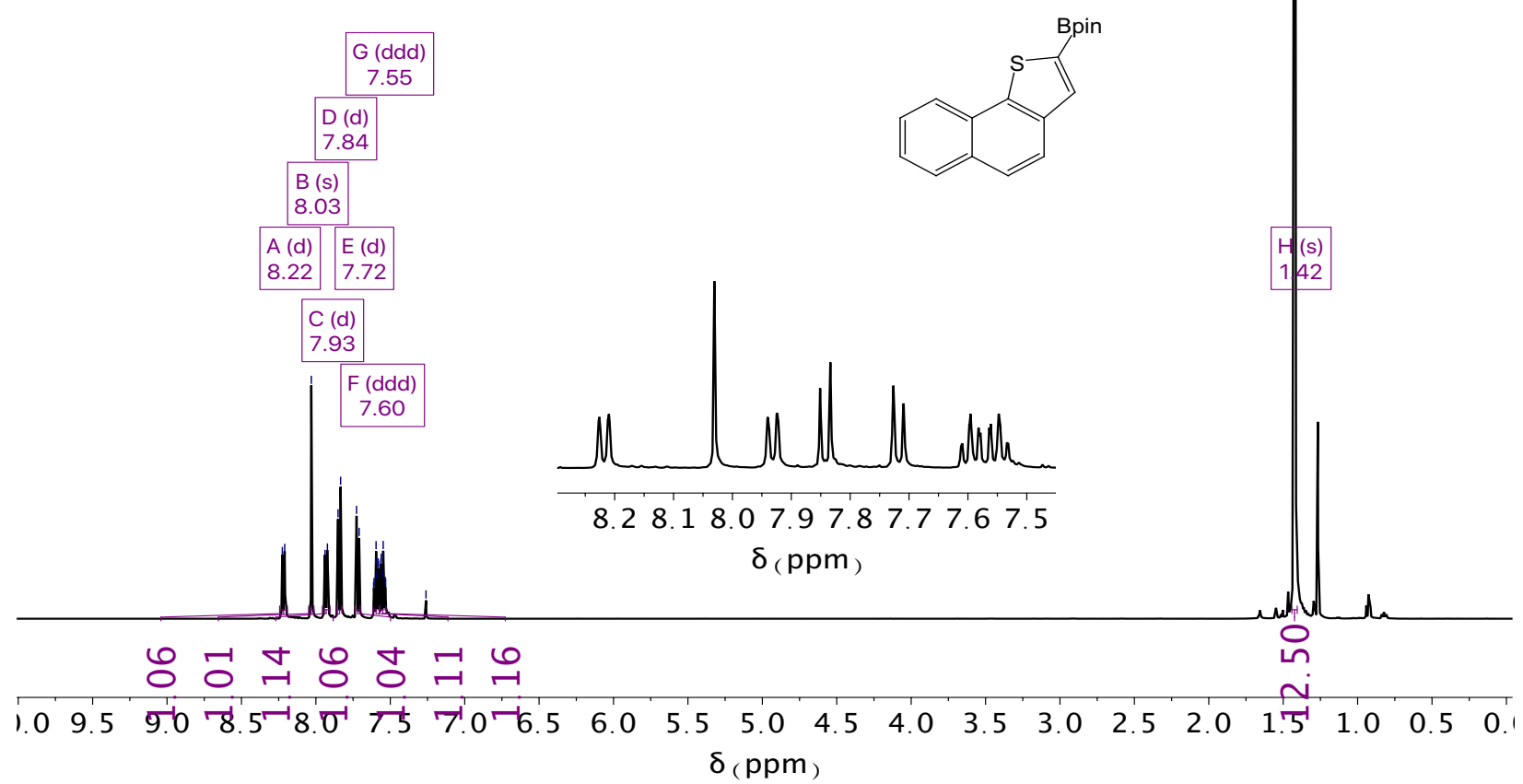

Figure S38. ${ }^{1} \mathrm{H}$ NMR spectrum $\left(\mathrm{CDCl}_{3}, 500 \mathrm{MHz}\right)$ of compound $\mathbf{1 2 b}$. 


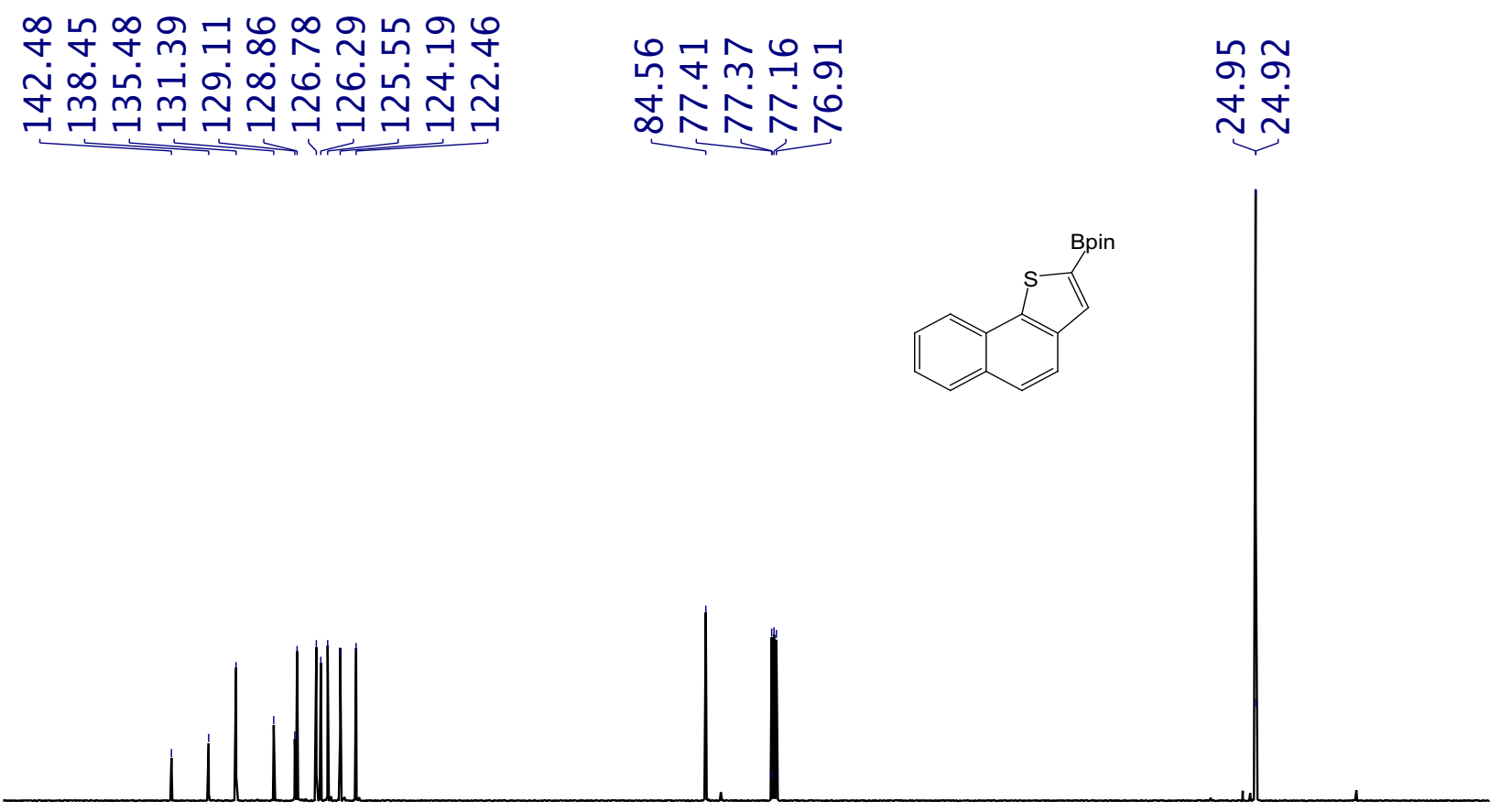

\begin{tabular}{|c|c|c|c|c|c|c|c|c|c|c|c|c|c|c|c|}
\hline 60 & 150 & 140 & 130 & 120 & 110 & 100 & 90 & $\begin{array}{r}80 \\
\text { (ppr }\end{array}$ & 70 & 60 & 50 & 40 & 30 & 20 & 10 \\
\hline
\end{tabular}

Figure S39. ${ }^{13} \mathrm{C}$ NMR spectrum $\left(\mathrm{CDCl}_{3}, 126 \mathrm{MHz}\right)$ of compound $\mathbf{1 2 b}$.

$\underset{1}{\infty}$
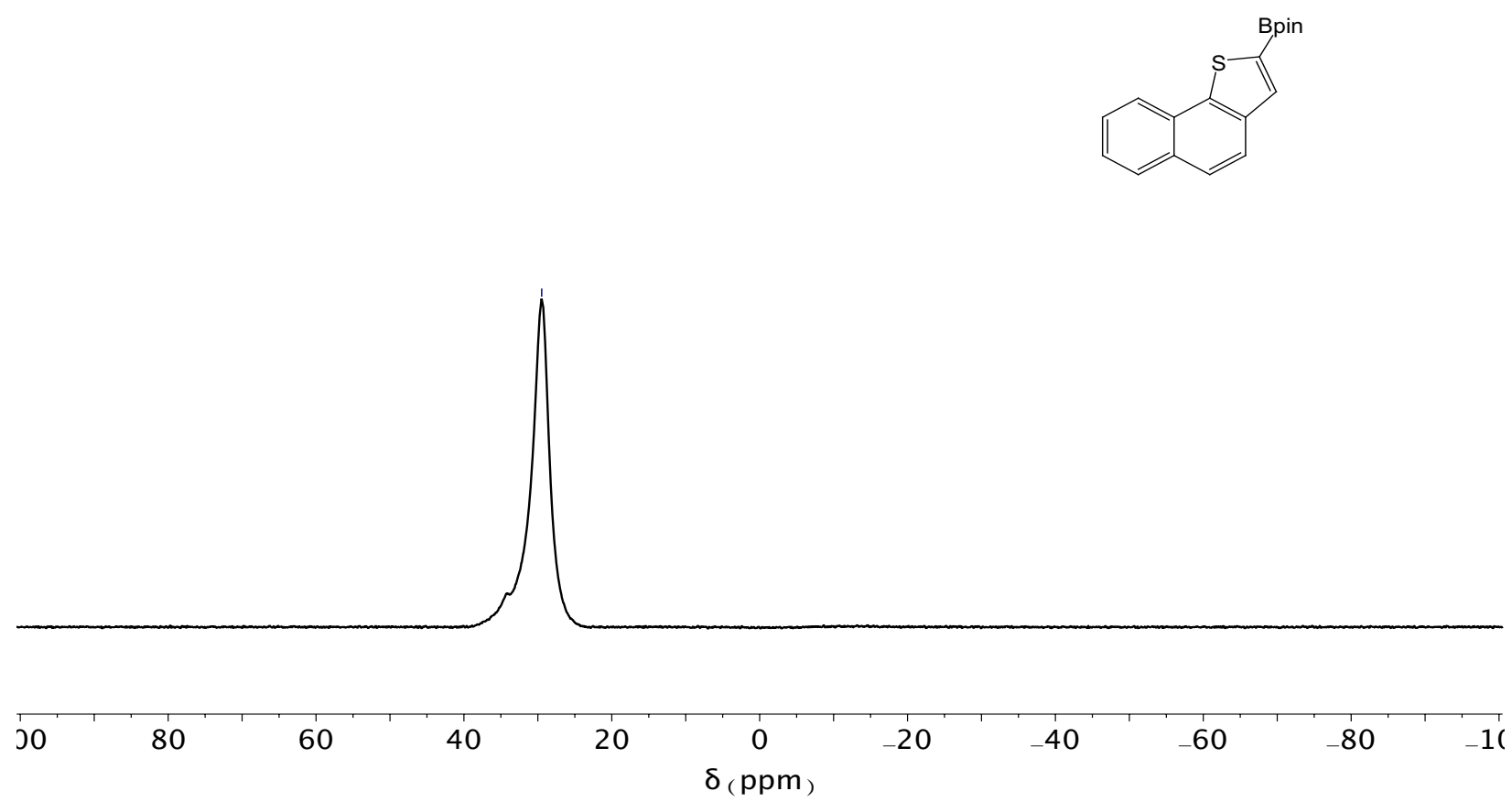

Figure S40. ${ }^{11} \mathrm{~B}$ NMR spectrum $\left(\mathrm{CDCl}_{3}, 160 \mathrm{MHz}\right)$ of compound $\mathbf{1 2 b}$. 
$\forall \sim m v \forall \sim 0 \infty 6 \sim 0$ \% ? $\infty \infty \times N$. $\infty \infty \infty N N$ 舟

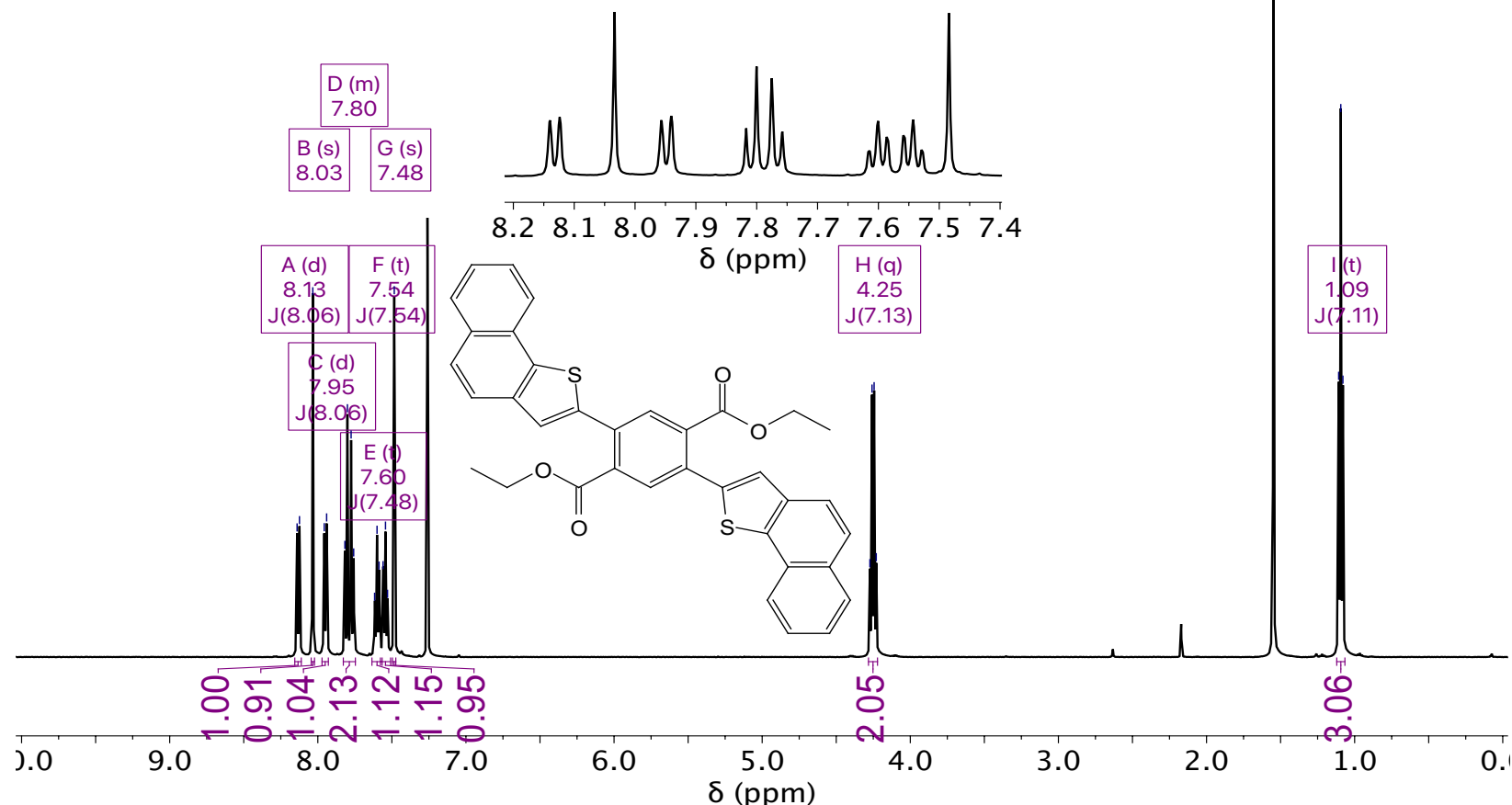

Figure S41. ${ }^{1} \mathrm{H}$ NMR spectrum $\left(\mathrm{CDCl}_{3}, 500 \mathrm{MHz}\right)$ of compound $\mathbf{1 4 b}$.

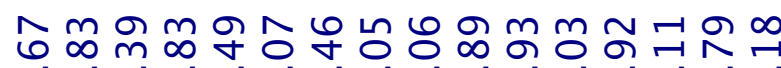
Nंक

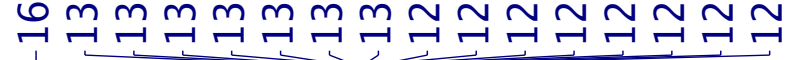
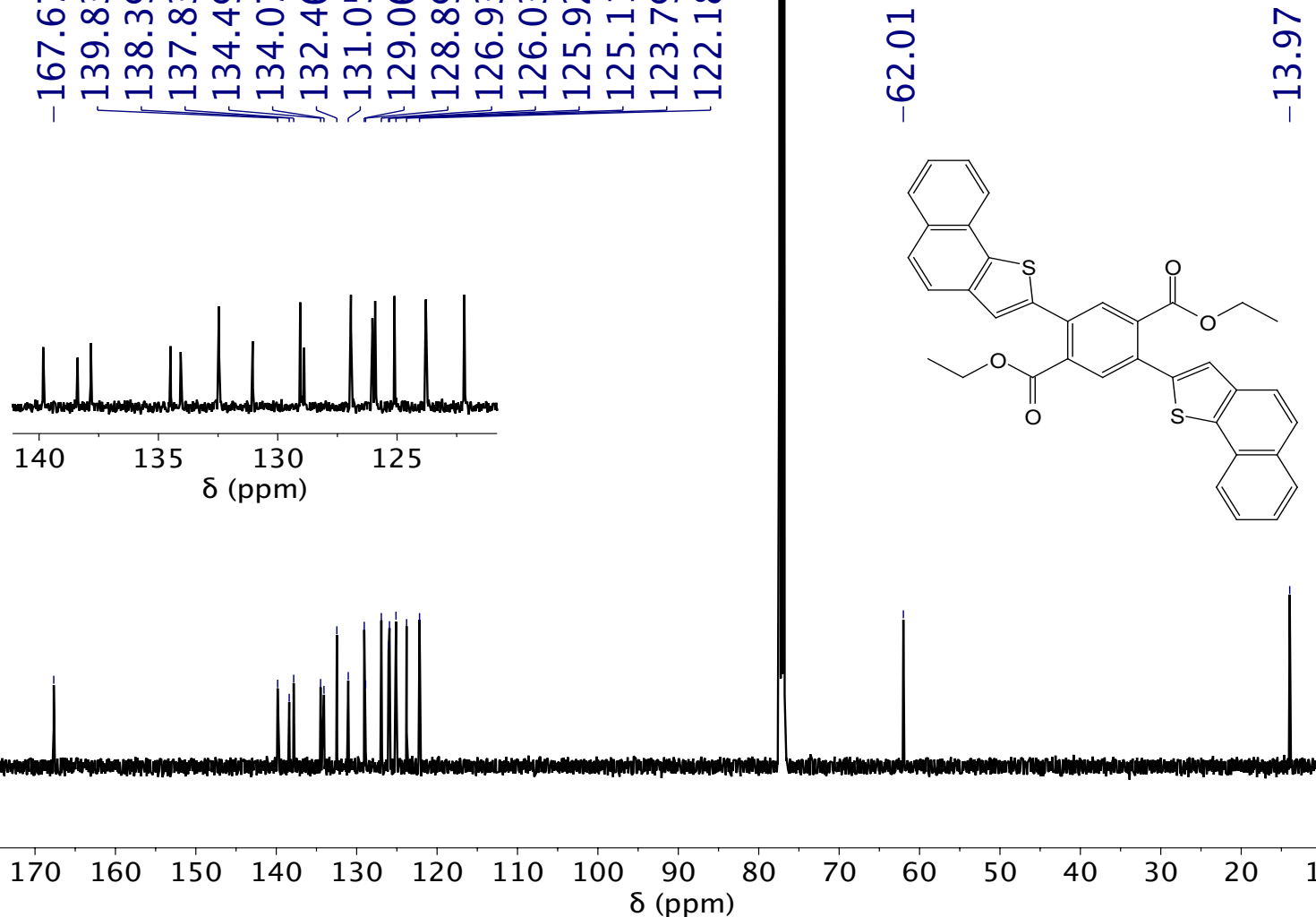

Figure S42. ${ }^{13} \mathrm{C}$ NMR spectrum $\left(\mathrm{CDCl}_{3}, 126 \mathrm{MHz}\right)$ of compound $\mathbf{1 4 b}$. 


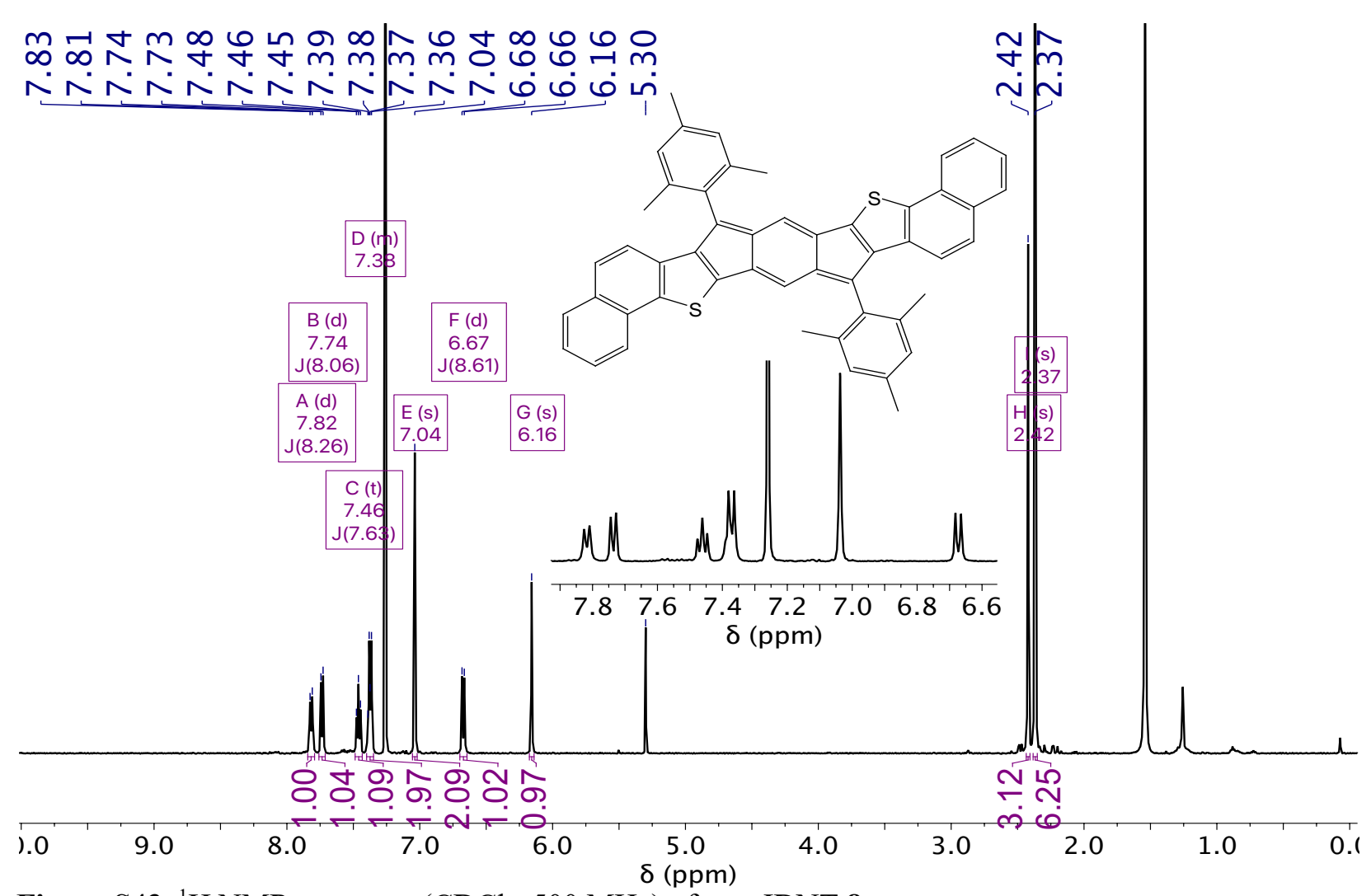

Figure S43. ${ }^{1} \mathrm{H}$ NMR spectrum $\left(\mathrm{CDCl}_{3}, 500 \mathrm{MHz}\right)$ of anti-IDNT 8.

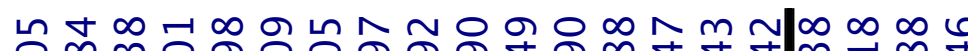

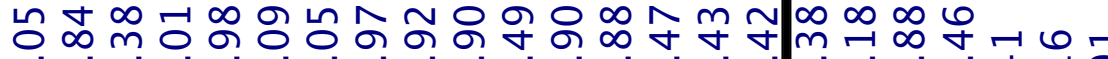
ம

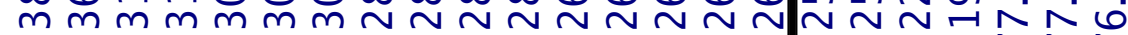
न $m$ न $m$ m N N N N

ペザ iं $\sim \sim \sim$

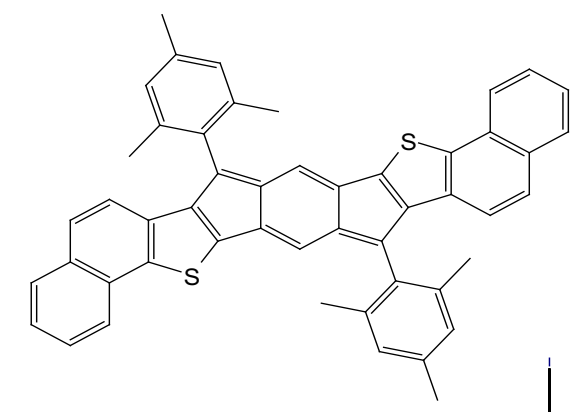

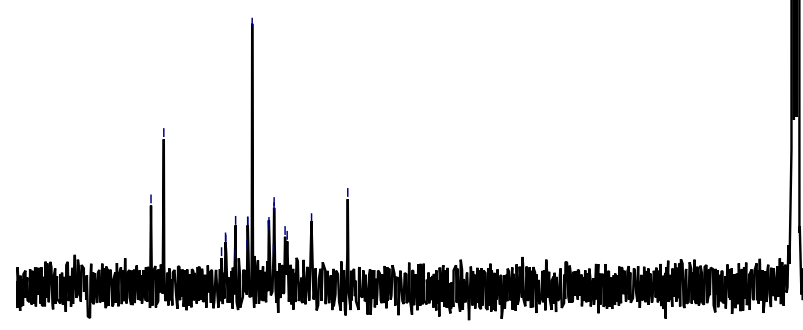

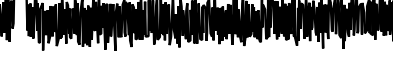

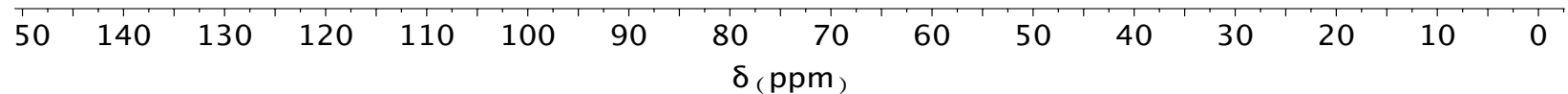

Figure $\mathbf{S 4 4} .{ }^{13} \mathrm{C}$ NMR spectrum $\left(\mathrm{CDCl}_{3}, 126 \mathrm{MHz}\right)$ of anti-IDNT 8. 


\section{References}

1. Niimi, K.; Mori, H.; Miyazaki, E.; Osaka, I.; Kakizoe, H.; Takimiya, K.; Adachi, C. [2,2']Bi[Naphtho[2,3-b]Furanyl]: A Versatile Organic Semiconductor with a Furan-Furan Junction. Chem. Commun. 2012, 48, 5892-5894.

2. Huisgen, R.; Sorge, G. Orientierungsphänomene bei der Substitution aromatischer Bicyclen III. Radikalsubstitutionen in der Naphthalinreihe. Justus Liebigs Ann. Chem. 1950, 566, 162-184.

3. Parham, W. E.; Wright, C. D. Formation of Naphthalenes from Indenes. IV. The Effect of Substitution at the Ethylenic Double Bond. J. Org. Chem. 1957, 22, 1473-1477.

4. Messersmith, R. E.; Siegler, M. A.; Tovar, J. D. Aromaticity Competition in Differentially Fused Borepin-Containing Polycyclic Aromatics. J. Org. Chem. 2016, 81, 5595-5605.

5. Reddy, C.; Shaikh, J. Y.; Bhat, R. G. Access to Hetero-Benzyl Scaffolds via TransientLigand-Enabled Direct $\gamma-\mathrm{C}\left(\mathrm{sp}^{3}\right)-\mathrm{H}$ Arylation of 3-Methylheteroarene-2-Carbaldehydes. J. Org. Chem. 2020, 85, 6924-6934.

6. Weimar, M.; Correa da Costa, R.; Lee, F.-H.; Fuchter, M. J. A Scalable and Expedient Route to 1-Aza[6]Helicene Derivatives and Its Subsequent Application to a Chiral-Relay Asymmetric Strategy. Org. Lett. 2013, 15, 1706-1709.

7. Sankar, E.; Raju, P.; Karunakaran, J.; Mohanakrishnan, A. K. Synthetic Utility of Arylmethylsulfones: Annulative $\pi$-Extension of Aromatics and Hetero-Aromatics Involving Pd(0)-Catalyzed Heck Coupling Reactions. J. Org. Chem. 2017, 82, 13583-13593.

8. Sheldrick, G. M. Bruker/Siemens Area Detector Absorption Correction Program, Bruker AXS, Madison, WI, 1998.

9. van der Sluis, P.; Spek, A. L. Acta Cryst., Sect. A 1990, A46, 194-201.

10. Sheldrick, G. M. Acta Cryst. 2015, C71, 3-8.

11. Gaussian 09, Revision E.01, Frisch, M. J.; Trucks, G. W.; Schlegel, H. B.; Scuseria, G. E.; Robb, M. A.; Cheeseman, J. R.; Scalmani, G.; Barone, V.; Mennucci, B.; Petersson, G. A.; Nakatsuji, H.; Caricato, M.; Li, X.; Hratchian, H. P.; Izmaylov, A. F.; Bloino, J.; Zheng, G.; Sonnenberg, J. L.; Hada, M.; Ehara, M.; Toyota, K.; Fukuda, R.; Hasegawa, J.; Ishida, M.; Nakajima, T.; Honda, Y.; Kitao, O.; Nakai, H.; Vreven, T.; Montgomery, J. A., Jr.; Peralta, J. E.; 
Ogliaro, F.; Bearpark, M.; Heyd, J. J.; Brothers, E.; Kudin, K. N.; Staroverov, V. N.; Kobayashi, R.; Normand, J.; Raghavachari, K.; Rendell, A.; Burant, J. C.; Iyengar, S. S.; Tomasi, J.; Cossi, M.; Rega, N.; Millam, J. M.; Klene, M.; Knox, J. E.; Cross, J. B.; Bakken, V.; Adamo, C.; Jaramillo, J.; Gomperts, R.; Stratmann, R. E.; Yazyev, O.; Austin, A. J.; Cammi, R.; Pomelli, C.; Ochterski, J. W.; Martin, R. L.; Morokuma, K.; Zakrzewski, V. G.; Voth, G. A.; Salvador, P.; Dannenberg, J. J.; Dapprich, S.; Daniels, A. D.; Farkas, Ö.; Foresman, J. B.; Ortiz, J. V.; Cioslowski, J.; Fox, D. J., Gaussian, Inc., Wallingford CT, 2013.

12. (a) Rahalkar, A.; Stanger, A. "Aroma”, http://schulich.technion.ac.il/Amnon_Stanger.htm (b) Stanger, A. J. Org. Chem. 2006, 71, 883-893. (c) Stanger, A. J. Org. Chem. 2010, 75, 2281-2288.

(d) Gershoni-Poranne, R.; Stanger, A. Chem. Eur. J. 2014, 20, 5673-5688.

13. NBO Version 3.1, Glendening, E. D.; Reed, A. E.; Carpenter, J. E.; Weinhold, F. 